\title{
Freshwater Resources and Saline Water Near the Sac And Fox Nation Tribal Lands, Eastern Lincoln County, Oklahoma
}

By Marvin M. Abbott

U.S. GEOLOGICAL SURVEY

Water-Resources Investigations Report 96-4173

Prepared in cooperation with the SAC AND FOX NATION

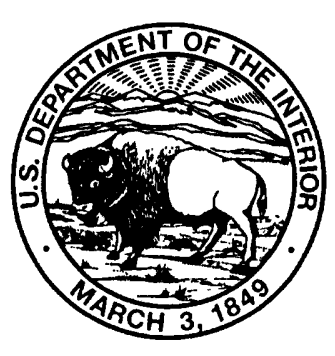




\section{U.S. DEPARTMENT OF THE INTERIOR \\ BRUCE BABBITT, Secretary}

U.S. GEOLOGICAL SURVEY

THOMAS J. CASADEVALL, Acting Director

Any use of trade names in this publication is for descriptive purposes

only and does not imply endorsement by the U.S. Government.

UNITED STATES GOVERNMENT PRINTING OFFICE: OKLAHOMA CITY 1998

For additional information

write to:

District Chief

U.S. Geological Survey

Water Resources Division

202 NW 66th Street, Building 7

Oklahoma City, OK 73116
Copies of this report can be purchased from:

U.S. Geological Survey

Branch of Information Services

Box 25286

Denver, CO 80225-0286 


\section{CONTENTS}

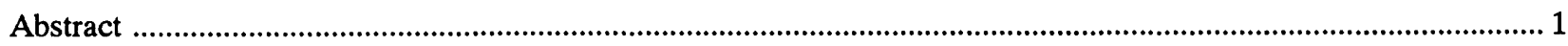

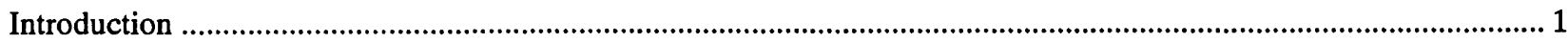

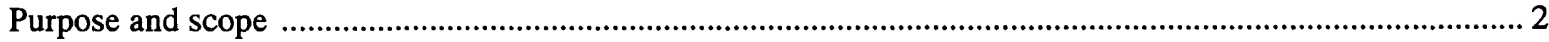

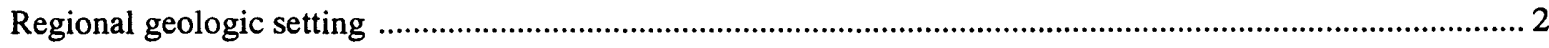

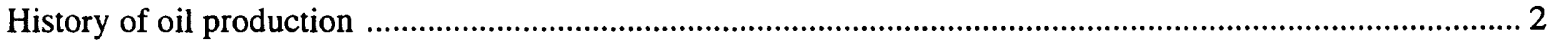

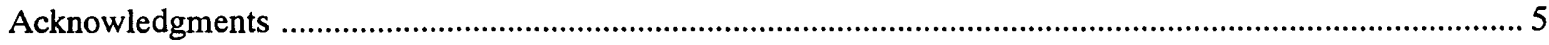

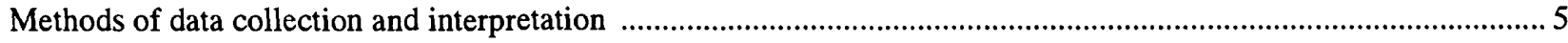

Sample collection, preparation, and chemical analysis .................................................................................. 5

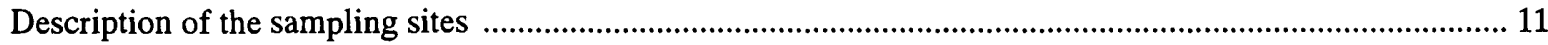

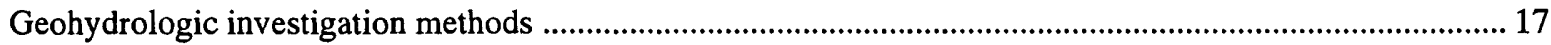

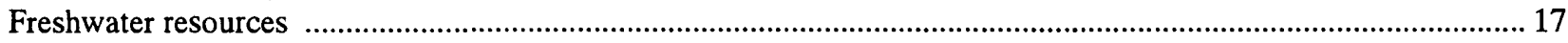

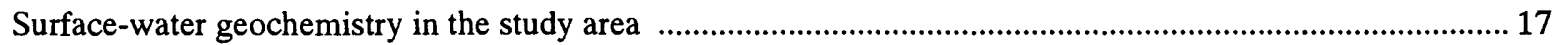

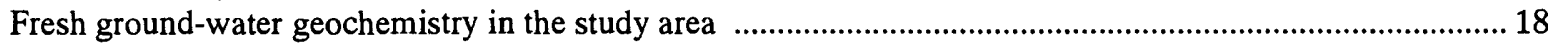

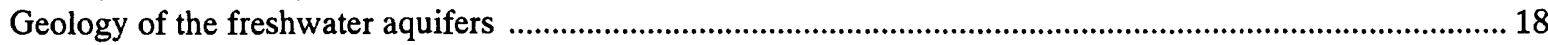

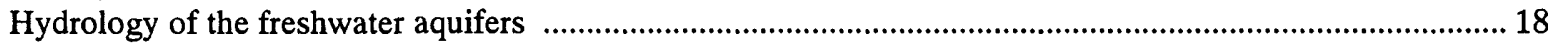

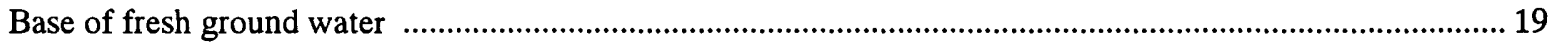

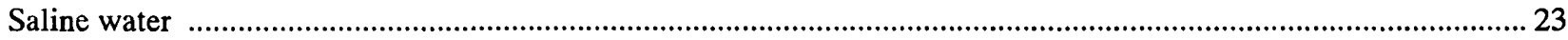

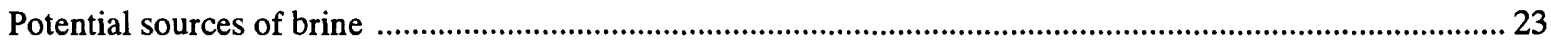

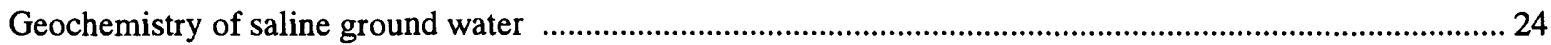

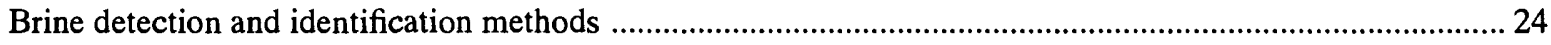

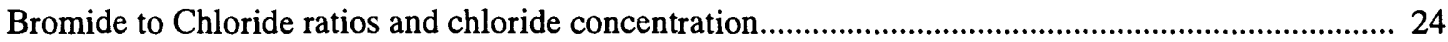

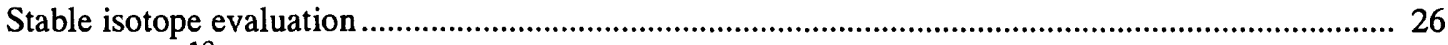

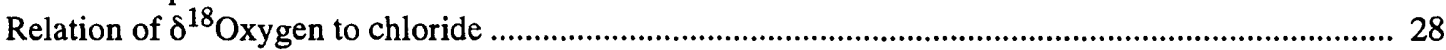

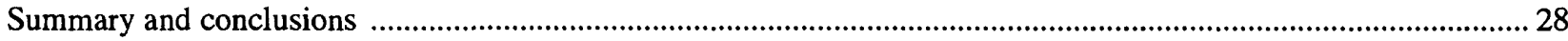

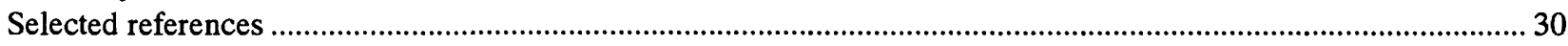

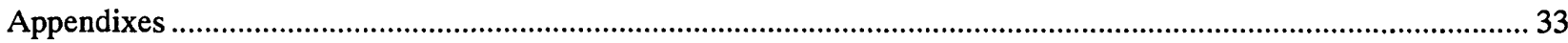

\section{ILLUSTRATIONS}

Figures

1. Map showing location of study area, water-chemistry sampling sites, and water-level well locations,

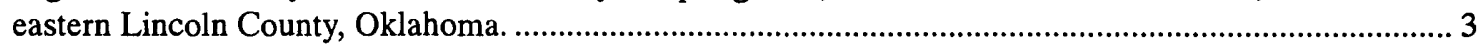

2. Major time-stratigraphic and selected geologic units in the study area................................................................ 4

3. Map showing location of water-chemistry sampling sites on and adjacent to the Sac and Fox Nation tribal

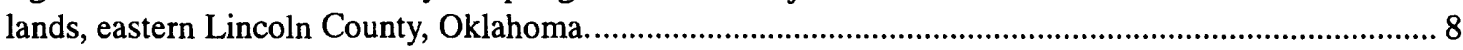

4-7 Geophysical logs showing:

4. Borehole $\mathrm{CH} 1$, sample interval for CH1-VS and CH1-VM, and screened interval for samples $\mathrm{CH} 2-\mathrm{VS}, \mathrm{CH} 3-\mathrm{VS}$, and $\mathrm{CH} 4-\mathrm{VS}$, in boreholes $\mathrm{CH} 2, \mathrm{CH} 3$, and $\mathrm{CH} 4$;

14N-06E-21 DAAA; eastern Lincoln County, Oklahoma.

5. Borehole CM1, sample interval for CM1-VM, and screened interval for sample

CM2-AD, in borehole CM2; 14N-06E-22 BAC; eastern Lincoln County, Oklahoma................. 14

6. Borehole WT1, screened and sample interval for WT1-AD and WT1-VM, and screened interval for samples WT2-VS and WT3-VS, in boreholes WT2 and WT3; 14N-06E-22 CAB;

eastern Lincoln County, Oklahoma.

7. Borehole L2, screened interval for $\mathrm{L} 2-\mathrm{VM} / \mathrm{T}$, and screened interval in borehole $\mathrm{L} 1 ; 14 \mathrm{~N}-06 \mathrm{E}-34 \mathrm{CBC}$; eastern Lincoln County, Oklahoma.......................................................................................... 16

8. Map of the altitude of the base of fresh ground water, from wells drilled between 1951-95, eastern

Lincoln County, Oklahoma.

9. Generalized hydrologic sections $A-A^{\prime}$ and $B-B$ ' showing relation between land surface and base of fresh ground water in the Ada-Vamoosa aquifer, 1951-95, eastern Lincoln County, Oklahoma. 
10-12 Graphs showing:

10. Relation between the ratio of bromide concentration to chloride concentration and chloride concentration in water samples, eastern Lincoln County, Oklahoma.

11. Relation between $\delta$ Deuterium and $\delta^{18}$ Oxygen (relative to standard mean ocean water [SMOW]), in eastern Lincoln County, Oklahoma.

12. Relation between $\delta^{18}$ Oxygen (relative to standard mean ocean water) and chloride molality, in eastern Lincoln County, Oklahoma

\section{TABLES}

1. Location and description of wells with water level measurements in the Ada-Vamoosa aquifer in the study area, on and near Sac and Fox Nation tribal land, eastern Lincoln County, Oklahoma ............................. 6

2. Listing of analytical methods used at the National Water Quality Laboratory..............................................................

3. Listing of analytical methods used at the National Water Quality Laboratory for stable isotopes............................. 11

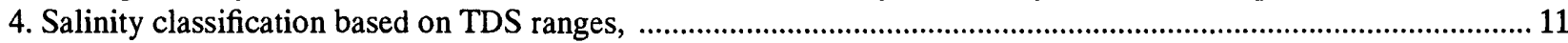




\section{Explanation of the Slte-numbering System}

The locations of the sample-collection sites are identified by a site-id number and a local identifier number. The site-id number is composed of the latitude and longitude of the location to the nearest second plus a sequence number. The location of the dot in the figure is latitude $35^{\circ} 40^{\prime} 23^{\prime \prime}$ and longitude $96^{\circ} 39^{\prime} 48^{\prime \prime}$. A sequence number is added to make the local identifier unique in the U.S. Geological Survey data base. If the sequence number is 1 , the complete site-id number is 354023096394801 . The local identifier number includes the township and range followed by the section and a series of letters that designate the quarter-section subdivisions, from the largest to the smallest. The order of the quarter-section subdivisions differs from that used by the U.S. Bureau of Land Management and the public land survey. As illustrated in the figure, the public land survey description of the site indicated by the dot as NE1/4 NE1/4 NE1/4 SE1/4 sec. 21, T. 14 N., R. 06 E., is denoted by the local identifier number 14N-06E-21 DAAA. If the sequence number is 1 , the complete identifier number is 14N-06E-21 DAAA 1 .

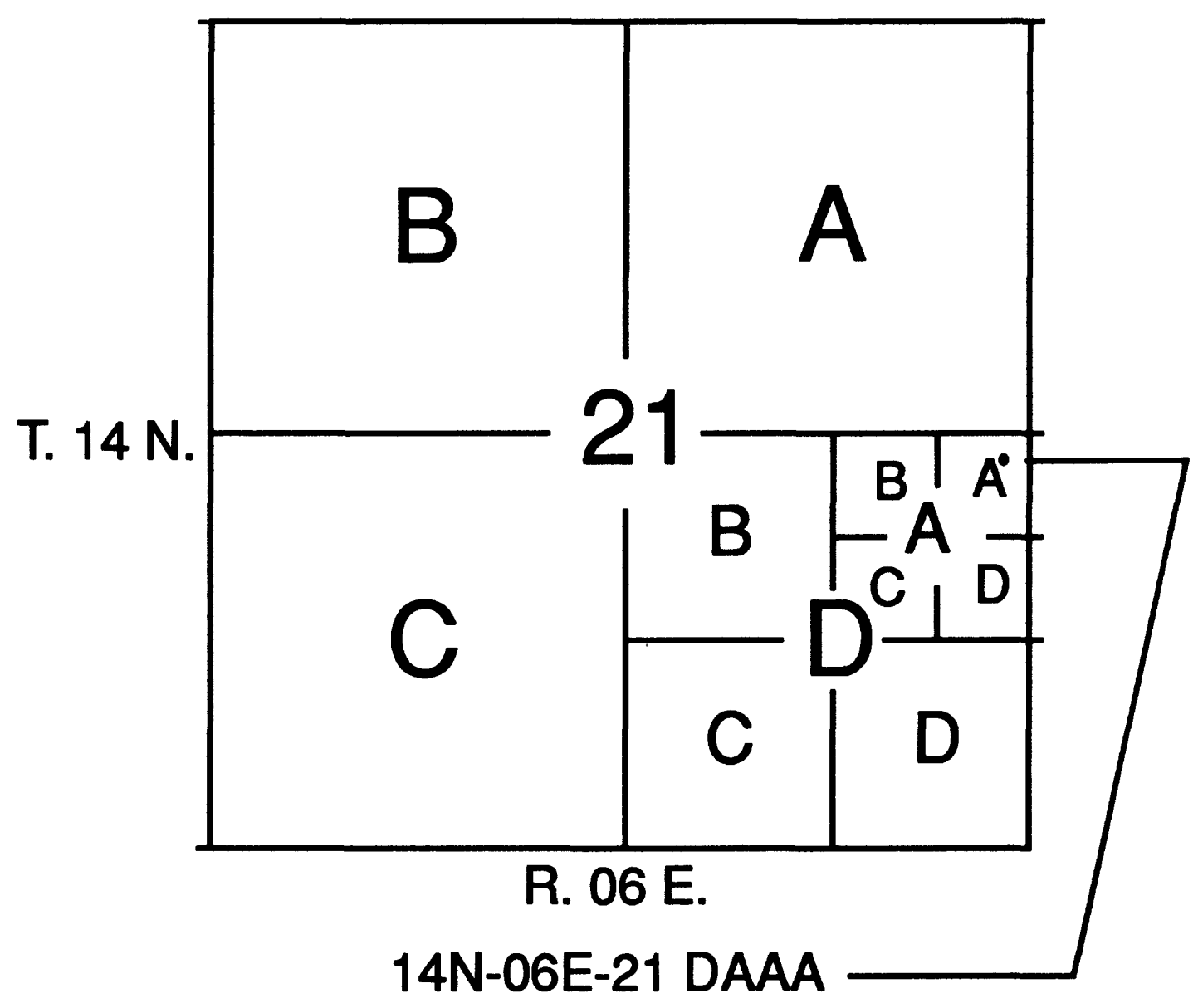




\section{CONVERSION FACTORS AND VERTICAL DATUM}

\begin{tabular}{|c|c|c|}
\hline Multoly & By & To obtaln \\
\hline foot (ft) & 0.3048 & meter \\
\hline foot per day (ft/d) & 0.3048 & meter per day \\
\hline foot per mile ( $\mathrm{ft} / \mathrm{mi})$ & 0.1894 & meter per kilometer \\
\hline foot squered per day $\left(\mathrm{ft}^{2} / d\right)$ & 0.0929 & meter squered per day \\
\hline cubic foot per second $\left(\mathrm{ft}^{3} / \mathrm{s}\right)$ & 0.02832 & cubic meter per second \\
\hline inch (in.) & 2.540 & centimeter \\
\hline mile (mi) & 1.609 & kilometer \\
\hline square mile $\left(\mathrm{mi}^{2}\right)$ & 2.590 & square kilometer \\
\hline \multicolumn{3}{|c|}{$\begin{array}{l}\left.\text { Temperature in degree Fahrenheit ("F) cen be converted to degree Celsius ( }{ }^{\circ} \mathrm{C}\right) \text { as follows: } \\
{ }^{\circ} \mathrm{C}=\left({ }^{\circ} \mathrm{F}-32\right) / 1.8 \\
\left.\text { Temperature in degree Celsius }\left({ }^{\circ} \mathrm{C}\right) \mathrm{cen} \text { be converted to degree Fahrenheit ( }{ }^{\circ} \mathrm{F}\right) \text { as follows: } \\
{ }^{\circ} \mathrm{F}=1.8^{\circ} \mathrm{C}+32\end{array}$} \\
\hline
\end{tabular}

Sea level: In this report "sea level" refers to the National Geodetic Vertical Datum of 1929 (NGVD of 1929) - geodetic datum derived from a general adjustment of the first-order level nets of both the United States and Canade, formerly callod Sea Level Datum of 1929. 


\title{
Freshwater Resources and Saline Water Near the Sac and Fox Nation Tribal Land, Eastern Lincoln County, Oklahoma
}

\author{
By Marvin M. Abbott
}

\section{Abstract}

The purpose of this project was to evaluate the freshwater resources and possible sources of high-chloride and high-sulfate concentrations in parts of the aquifer near the Sac and Fox Nation tribal land in eastern Lincoln County, Oklahoma. Water-quality sampling and borehole geophysical data indicate the potential for fresh ground water on tribal land generally is greatest in the Vanoss Formation, in the SE1/4 sec. 21, T. 14 N., R. $06 \mathrm{E}$. and in the NE1/4 sec. 22, T. 14 N., R. 06 E. These locations avoid the flood-prone areas and borehole geophysical resistivity logs indicate the altitude of the base of fresh ground water is below $650 \mathrm{ft}$. The altitude of the base of fresh ground water is indicated to be generally near the surface under the W1/2 sec. 22, T. 14 N., R. 06 E., the SE1/4 sec. 22 , SE1/4 SE1/4 NE1/4 sec. 21, and NE1/4 NW1/4 NW1/4 sec. 27.

Conditions are more favorable for placement of fresh ground-water wells in sec. 34, T. 14 N., R. $06 \mathrm{E}$., where the tribe has leased water rights, than on tribal land in secs. 15, 16, 21, and 22, T. 14 N., R. $06 \mathrm{E}$. Sandstones overlain by or enclosed in thick clay and shale sequences are likely to be somewhat isolated from the flow system and retain some of the residual brine. Borehole geophysical logs suggest that sandstones near CH1, CM1, and WT1 have more clay and shale content than the sandstones near L2. Greater amounts of clay in the sandstones will retard the flushing of residual brines from the sandstones and could result in a shallow base of fresh water near CH1, CM1, and WT1. For these reasons and because circulation of fresh ground water is limited by discharge to the Deep Fork, general water quality under tribal land would probably be poorer than in the area where the tribe has leased water rights.
Samples have chloride or sulfate concentrations greater than 250 milligrams per liter in the W1/2 sec. 22, T. 14 N., R. 06 E. Six cluster well samples from tribal land have chloride or sulfate concentrations above the suggested maximum contaminant levels set by U.S. Environmental Protection Agency.

Water-quality data indicate there may be more than one source for the salinity in the very saline and briny samples near the tribal land. Two possible sources for chloride and sulfate in waterquality samples are shallow brines and deep oil brines. Probable sources of shallow brines in the study area are: 1) solution of minerals by fresh water moving through the aquifer and 2) residual brines deposited with the sediment. There are no salt or gypsum beds in the Vanoss, Ada, or Vamoosa Formations, but there may be nodules and finely disseminated minerals present in the formations. Residual brines could remain in sandstones and shales that have low hydraulic conductivity and have not been diluted by freshwater recharge. Data suggest both sources have mixed with the fresh ground water from the Vanoss Formation. This is indicated by the relations of the bromide/chloride concentration ratio to chloride concentration, $\delta \mathrm{D}$ to $\delta^{18} \mathrm{O}$, and by $\delta^{18} \mathrm{O}$ to chloride molality relation.

\section{INTRODUCTION}

The Sac and Fox Nation tribal land consists of 960 acres located in eastern Lincoln County, Oklahoma. The location is $3.5 \mathrm{mi}$ south of the town of Stroud, Oklahoma, and is bounded on three sides by the Deep Fork and an extensive wetlands area along the river flood plain (fig. 1). The Deep Fork is a tributary of the North Canadian River and flows from west to east across the study area. The river has an average altitude of $770 \mathrm{ft}$ above sea level and has a vertical drop of 
approximately $20 \mathrm{ft}$ along $8 \mathrm{mi}$ in the study area. Low rolling hills from $\mathbf{4 0}$ to $120 \mathrm{ft}$ high characterize the area. The mean annual precipitation is about $36 \mathrm{in}$. of rainfall and the average annual temperature is about 15 degrees ${ }^{\circ} \mathrm{C}$.

Water from domestic supply wells in sec. $21, T$. 14 N., R. 06 E. has become increasingly saline in recent years. The Sac and Fox consider the ground water unusable on the tribal land; and the tribe has leased water rights in sec. 34, T. 14 N., R. 06 E. Stratigraphically equivalent sandstones north and south of the tribal land produce potable water. Potential saline sources in the area are surface water from the Deep Fork, shallow brines, and brines from oil production at approximately $3,000 \mathrm{ft}$. The U.S. Geological Survey in cooperation with the Sac and Fox Nation initiated a study to evaluate shallow ground water as a drinkingwater supply and potential sources of high saline water on and near the tribal land.

\section{Purpose and Scope}

The purpose of this report is to describe freshwater resources and evaluate possible sources of highchloride and high-sulfate concentrations in parts of the aquifer. Data are interpreted to determine (1) whether ground water near the Sac and Fox Nation tribal land meets drinking-water standards and (2) where the ground water quality does not meet these standards, how large an area may be affected. The report discusses the general geohydrology of the freshwater aquifer and the probable sources of high-chloride and high-sulfate concentrations in the area.

Water-quality samples, well clusters, and borehole geophysical logs were used to investigate the area. Water-quality samples from a $40 \mathrm{mi}^{2}$ area included surface water from the Deep Fork, ground water, and produced oil-field brines. Well clusters were installed at four locations in the study area on and near tribal land. The well clusters were used to sample selected permeable zones in the aquifer. Borehole geophysical logs were used for subsurface mapping and for better definition of the lateral extent of the sandstone aquifers.

\section{Reglonal Geologic Setting}

The stratigraphy in the region has been discussed by several authors. Morton (1986) described the Ada-Vamoosa aquifer as a bedrock sequence of Pennsylvanian formations that are lithologically similar and hydrologically connected. These include in ascending order the Barnsdall, Tallant, Vamoosa, Ada, and Vanoss Formations (fig. 2). Fresh ground water in the study area is in rocks of the Vamoosa, Ada, and Vanoss Formations of the Virgilian Series. Masters (1958) described the geology of the Prague area, $12 \mathrm{mi}$ south of the tribal land (fig. 1). Oakes and Branson (1956) described the stratigraphy along the Tumer Turnpike, $5 \mathrm{mi}$ north of the tribal headquarters, not shown on figure 1. Oakes (1959) described the geology of Creek County east of the study area. Ries (1954) described the geology of Okfuskee County, to the southeast.

Faults have been mapped in the area in a northsouth en 'echelon band. The individual faults strike generally northwest at about $20^{\circ}$ (D'Lugosz and others, 1986). The geologic map by Bingham and Moore (1975) indicates two such faults in the aquifer north of the Deep Fork. D'Lugosz and others (1986) reported these faults average about $2 \mathrm{mi}$ in length and most are normal faults down thrown to the west. The faults usually have $50 \mathrm{ft}$ of vertical displacement in the study area and rarely exceed $100 \mathrm{ft}$ (D'Lugosz and others, 1986). The depth of influence of these faults in the study area is not known. In the Seminole oil field, 30 $\mathrm{mi}$ to the south, Levorsen (1929) noted the depth of such faults was limited to $600 \mathrm{ft}$ and some were only 100 to $300 \mathrm{ft}$ deep. His subsurface work suggests that the displacement on these faults decreases with depth.

\section{History of Oll Production}

Oil production began in the 1930 's from the Prue sand at depths of 2,900 to $3,100 \mathrm{ft}$ below land surface. The Prue sand is the upper informal subsurface unit of the Senora Formation (fig. 2). All the oil production in T. 14 N., R. 06 E., secs. 14, 15, 16, 21, $22,23,26,27$, and 28 is from the Prue sand. There have been 183 wells drilled for oil and gas in secs. 15 , 16,21 , and 22 on which the tribal land is located.

There are other formations that produce oil in the township. These include the Simpson Group, the Viola Limestone, and the Bartlesville sand in secs. 12 and 35. The Hunton Group is productive in the NW1/4 sec. 10 and the SW $1 / 4$ sec. 3 . These formations are older than the Prue sand and are approximately 4,000 $\mathrm{ft}$ below land surface in the area (Cole, 1958). 


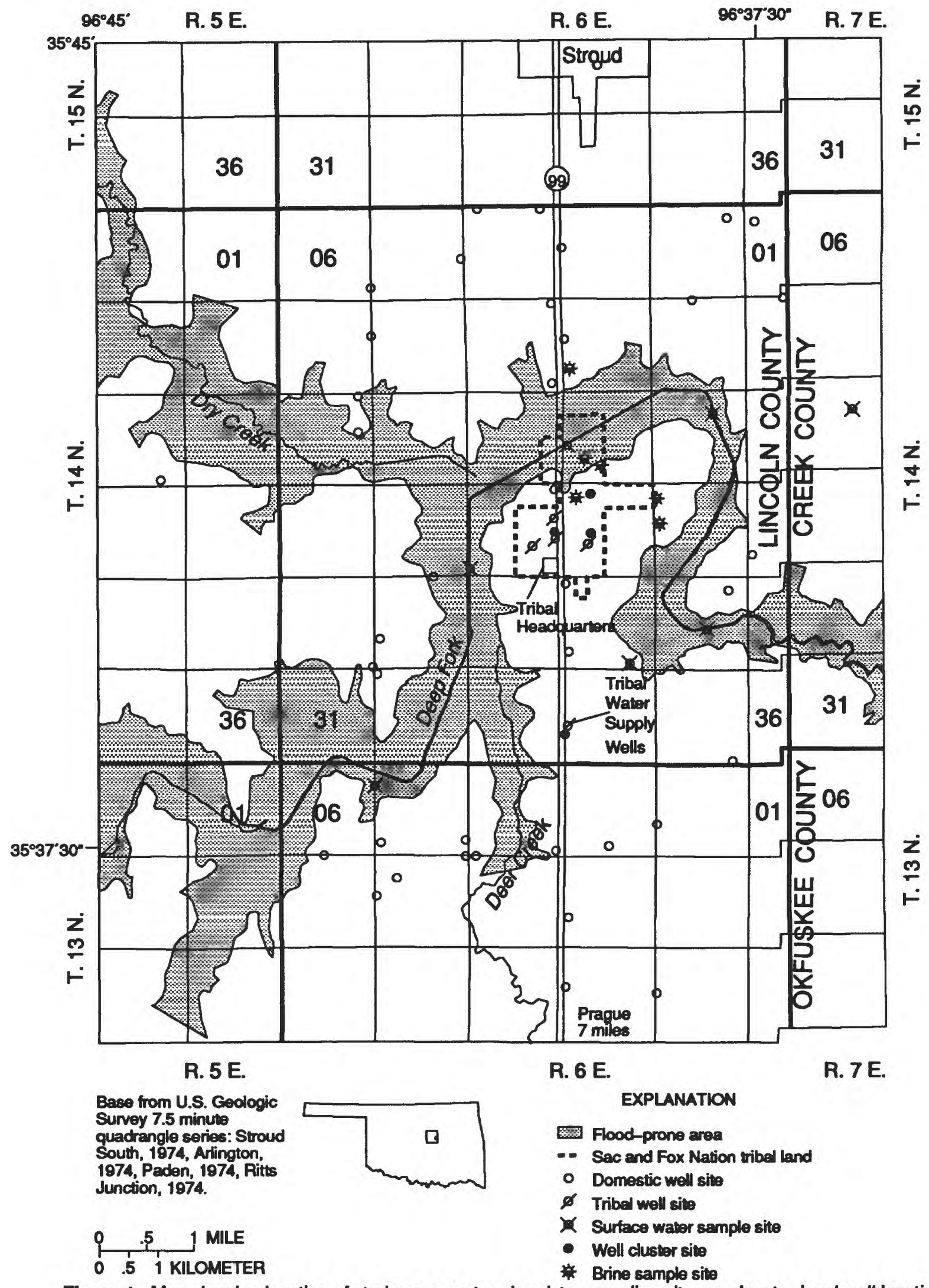

Flgure 1. Map showing location of study area, water-chemistry sampling sites, and water-level well locations, eastern Lincoln County, Oklahoma. 


\begin{tabular}{|c|c|c|c|c|c|}
\hline System & Serise & Group & Formation & Momber & $\begin{array}{l}\text { Informal } \\
\text { subeuriace unit }\end{array}$ \\
\hline \multirow{24}{*}{ 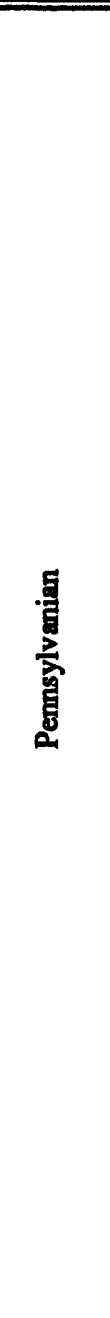 } & \multirow{5}{*}{$\begin{array}{l}\text { 墨 } \\
\text { 昜 }\end{array}$} & & Vanoss Formation & & \\
\hline & & & \multirow{3}{*}{ Ada Formation } & Turkey Run Limestone & \\
\hline & & & & & \\
\hline & & & & Lecompton Limestone & \\
\hline & & & Vamoosa Formation & & \\
\hline & \multirow{11}{*}{$\begin{array}{l}\mathbf{5} \\
\frac{5}{8} \\
\frac{8}{2}\end{array}$} & \multirow{5}{*}{ Ochelata } & Tallent Formation & & \\
\hline & & & Barnsdall Formation & & \\
\hline & & & Wann Formation & & \\
\hline & & & Iola Formation & & \\
\hline & & & Chenute Formation & & \\
\hline & & \multirow{6}{*}{ Skiatook } & Dewey Limestone & & \\
\hline & & & Nellie Bly Formation & & \\
\hline & & & Hogshooter Limestone & & \\
\hline & & & Coffeyville Formation & & \\
\hline & & & Checkerbourd Limentone & & \\
\hline & & & Seminole Formation & & \\
\hline & \multirow{8}{*}{ 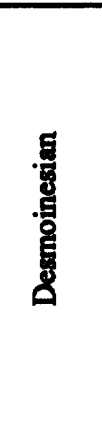 } & Mermaton & & & \\
\hline & & \multirow{3}{*}{ Cabaniss } & Senora Formation & & Prue send \\
\hline & & & Stuart Shele & & \\
\hline & & & Therrman Sandetone & & \\
\hline & & \multirow{4}{*}{ Krebs } & Boggy Formation & & Bertlesville send \\
\hline & & & Savanna Formation & & \\
\hline & & & MaAlester Formation & & \\
\hline & & & Hartshome Sendetone & & \\
\hline \multicolumn{6}{|c|}{ Undifferentiated rocks of Silurian, Devonian, Mississippian, and Early Pennsylvanien age in the subsurface } \\
\hline 鸹 & & Hunton & & & \\
\hline \multirow{5}{*}{$\begin{array}{l}\frac{8}{0} \\
\frac{8}{8} \\
8\end{array}$} & & & Sylven Shale & & \\
\hline & & & Fenvale Limestone & & \\
\hline & & & Viola Limestone & & \\
\hline & & Simpeon & & & \\
\hline & & Arbuckle & & & \\
\hline
\end{tabular}

Figure 2. Major time-stratigraphic and solocted geologic units in the study area (from Mieor, 1954; Oklahoma Corporation Commission, written commun., 1995). 
The Oklahoma Corporation Commission formed the Sac and Fox Prue Sand Unit in 1952 and the Southeast Sac and Fox Prue Sand Unit in 1954. These are areas where the oil production is derived from a common source of supply. Secondary recovery efforts by waterflooding of the producing formation began the year the units were formed. Waterflooding is the process of injecting water under pressure to drive the remaining oil to the producing wells. During waterflooding many of the producing wells were converted to injection wells. Information and data pertaining to oil-well locations, oil production, and waterflooding activities were obtained from documents from the Oklahoma Corporation Commission.

\section{Acknowledgments}

The author wishes to express his gratitude to the organizations and individuals who contributed and assisted in the project. Special thanks are given to Chief Elmer Manatowa and the members of the Sac and Fox Nation who were helpful and cooperative during the field work. Many area farmers assisted greatly by supplying information concerning construction of their wells and by allowing water samples to be collected from their wells. Robert Gordon Oil Company, the operator of the oil production at the time the wells were sampled, permitted sampling of their wells and supplied personnel to assist with well-head connections. Jack Lewis permitted two observation wells to be drilled on his property near the tribal water-supply wells.

\section{METHODS OF DATA COLLECTION AND INTERPRETATION}

This study first investigated the regional ground-water system within a 3-mi radius of tribal land (fig. 1) to evaluate the general water quality. Water levels were measured in $\mathbf{4 3}$ wells during this well inventory in 1990 (table 1). Fifty-eight water samples were collected from June 1990 through June 1993. Thirty of these samples were collected from domestic wells (fig. 1) and from four existing unused wells that were on tribal land (fig. 3). Eleven waterquality samples were taken from the three well clusters on tribal land and three from land where the tribe has leased water rights. Four surface-water samples- from the Deep Fork and six deep oil-field brines samples also were collected.

The regional geohydrology was investigated using borehole geophysical logs. The geophysical logs provided information on the thickness and continuity of the aquifers. A map of the altitude of the base of fresh ground water was constructed from resistivity logs of wells drilled after 1950.

\section{Sample Collection, Preparation, and Chemical Analysis}

Specific conductance, dissolved oxygen, pH, and temperature were measured with portable field meters. Alkalinity was measured by an incremental titration (Wells and others, 1990) of a filtered aliquot. Water samples collected from wells were taken after consistent measurements of specific conductance, dissolved oxygen, $\mathrm{pH}$, and temperature were obtained in a flow-through cell. Where sustained flow could not be obtained from a well, a sample was collected after the well had been purged of at least three borehole volumes of water.

All analyses were performed by the U.S. Geological Survey National Water Quality Laboratory in Arvada, Colorado. The analytical methods used in the analyses are listed in tables 2 and 3. Specific conductance, pH, major elements, and trace elements (table 2) were determined using standard methods described in Fishman and Friedman (1989). The radiochemical analyses (table 2) were determined using standard methods as described in Thatcher and others (1977). Stable isotopes (table 3) of hydrogen and oxygen were determined using mass spectrometry. The relative difference in the ratio of the heavy isotope to the more abundant lighter isotope was determined for each sample and compared to the ratio of a standard. The ratios are reported in parts per thousand (permil) difference from the standard. The results are reported relative to standard mean ocean water (SMOW). The reported values are designated by the Greek letter " 8 " A complete discussion of stable isotope hydrology is given by Gat and Gonfiantini (1981).

The analytical results are summarized for ground water in appendix 1 and surface water in appendix 2 . Samples collected during the investigation of the regional ground-water system in $\mathbf{1 9 9 0}$ were not analyzed for trace metals, fluoride, silica, radium-226, radon-222, or stable isotopes. The remaining samples 
Table 1. Location and description of wolls with water lovel messuroments in the Ada-Vamoosa aquifer in the study area, on and near Sac and Fox Nation tribal land, eastern Lincoln County, Oklahoma

[Aquifer codes: 322VNSS, Vanous Formation; 322ADA, Ada Formation]

\begin{tabular}{|c|c|c|c|c|c|c|c|}
\hline Local well number & She ID & $\begin{array}{l}\text { Aquilior } \\
\text { code }\end{array}$ & $\begin{array}{l}\text { Altitudo } \\
\text { of } \\
\text { land } \\
\text { eurfaces } \\
\text { (foet } \\
\text { above } \\
\text { eac } \\
\text { lovel) }\end{array}$ & $\begin{array}{l}\text { Depth of } \\
\text { well } \\
\text { (ivet below } \\
\text { land } \\
\text { surfece) }\end{array}$ & $\begin{array}{l}\text { Water loved } \\
\text { (dato) }\end{array}$ & $\begin{array}{l}\text { Walor lowed } \\
\text { (licet below } \\
\text { land } \\
\text { curtice) }\end{array}$ & 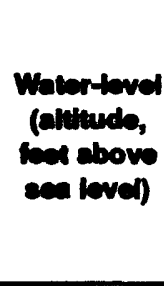 \\
\hline $13 \mathrm{~N}-06 \mathrm{E}-02 \mathrm{CBC} 1$ & 353738096383901 & 322VNSS & 905 & 40 & 03-21-90 & 2.0 & 903.0 \\
\hline 13N-06E-03 CCB 1 & 353733096373101 & 322VNSS & 870 & 84 & $03-16-90$ & 35.79 & 834.21 \\
\hline 13N-06E-03 CDD 1 & 353726096391201 & 322 VNSS & 890 & 185 & $03-20-90$ & 78.60 & 811.40 \\
\hline 13N-06E-04 DDD 1 & 353721096394501 & 322 VNSS & 860 & 162 & $03-16-90$ & 39.52 & 820.48 \\
\hline 13N-06E-05 CCC 1 & 353729096414801 & 322VNSS & 825 & 171 & $03-20-90$ & 50.63 & 774.37 \\
\hline 13N-06E-08 AAA 2 & 353721096405001 & 322 VNSS & 850 & 121 & $03-20-90$ & 63.70 & 786.30 \\
\hline $13 \mathrm{~N}-06 \mathrm{E}-08 \mathrm{BCC} 1$ & 353659096415101 & 322 VNSS & 895 & 216.4 & $04-04-90$ & 117.28 & 777.72 \\
\hline 13N-06E-08 BDB 1 & 353709096413701 & 322 VNSS & 880 & 174 & $03-20-90$ & 80.00 & 800.00 \\
\hline 13N-06E-09 BBB 1 & 353721096404301 & 322 VNSS & 825 & 68 & $03-20-90$ & 37.0 & 788.0 \\
\hline $13 \mathrm{~N}-06 \mathrm{E}-10 \mathrm{CBC} 1$ & 353646096394301 & 322 VNSS & 815 & 45 & $04-03-90$ & 12.0 & 803.0 \\
\hline 13N-06E-14 BCC 1 & 353603096384001 & 322 VNSS & 890 & 180 & $03-28-90$ & 106.0 & 784.0 \\
\hline 14N-05E-14 DCD 1 & 354053096441701 & 322 VNSS & 860 & 108 & 04-04-90 & 68.75 & 791.25 \\
\hline $14 \mathrm{~N}-06 \mathrm{E}-02 \mathrm{AAB} 1$ & 354319096374901 & 322 VNSS & 875 & 95 & $03-21-90$ & 77.50 & 797.50 \\
\hline $14 \mathrm{~N}-06 \mathrm{E}-03 \mathrm{BCC} 1$ & 354303096394201 & 322ADA & 850 & 279 & 03-15-90 & 86.43 & 763.57 \\
\hline 14N-06E-04 AAB 1 & 354325096395701 & 322VNSS & 820 & 100 & 03-21-90 & 37.98 & 782.02 \\
\hline 14N-06E-04 BBA 1 & 354325096404001 & 322 VNSS & 890 & 172 & $03-15-90$ & 80.50 & 809.50 \\
\hline 14N-06E-05 DAA 1 & 354257096405101 & 322 VNSS & 850 & 90.5 & $03-13-90$ & 52.80 & 797.20 \\
\hline 14N-06E-06 DAD 1 & 354253096425301 & $322 \mathrm{VNSS}$ & 860 & 1425 & 03-15-90 & 56.00 & 804.00 \\
\hline 14N-06E-07 ADA 1 & 354241096415301 & 322 VNSS & 830 & 136 & $03-13-90$ & 34.10 & 795.90 \\
\hline 14N-06E-07 ADD 1 & 354214096415301 & 322 VNSS & 815 & 132 & 03-13-90 & 23.04 & 791.96 \\
\hline 14N-06E-09 AAA 1 & 354233096394701 & 322 VNSS & 840 & 95.5 & $03-15-90$ & 34.51 & 805.49 \\
\hline 14N-06E-09 DDD 1 & 354150096394601 & 322ADA & 806 & 142 & $03-20-90$ & 45.73 & 760.27 \\
\hline $14 \mathrm{~N}-06 \mathrm{E}-10 \mathrm{BCC} 1$ & 354211096394301 & 322ADA & 830 & 184 & $03-16-90$ & 51.70 & 778.30 \\
\hline $14 \mathrm{~N}-06 \mathrm{E}-18 \mathrm{AAB} 1$ & 354140096420201 & 322 VNSS & 800 & 78.7 & $03-16-90$ & 19.96 & 780.04 \\
\hline 14N-06E-18 ADD 1 & 354120096420201 & 322 VNSS & 780 & 37 & $03-20-90$ & 17.89 & 762.11 \\
\hline 14N-06E-21 AAA 1 & 354008096404601 & 322 VNSS & 820 & 116 & $03-19-90$ & 106.00 & 714.00 \\
\hline $14 \mathrm{~N}-06 \mathrm{E}-21$ ADD 1 & 354030096394501 & 322 VNSS & 830 & 87.5 & $03-28-90$ & 8.06 & 821.94 \\
\hline 14N-06E-21 DAA 1 & 354019096394501 & 322VNSS & 832 & 77 & 03-15-90 & 10.56 & 821.44 \\
\hline 14N-06E-21 DAAA 2 & 354023096394804 & 322 VNSS & 832 & 140 & $09-21-92$ & 38.26 & 793.74 \\
\hline 14N-06E-21 DAAA 3 & 354023096394805 & 322VNSS & 832 & 95 & $09-21-92$ & 18.35 & 813.65 \\
\hline
\end{tabular}


Table 1. Location and description of wells with water lovel measurements in the Ada-Vamoosa aquifor in the study area, on and near Sac and Fox Nation tribal land, eastorn Lincoln County, Oklahoma - Continued

\begin{tabular}{|c|c|c|c|c|c|c|c|}
\hline Local well number & Site ID & $\begin{array}{l}\text { Aquifer } \\
\text { code }\end{array}$ & $\begin{array}{l}\text { Althude } \\
\text { of } \\
\text { land } \\
\text { surfaco } \\
\text { (foot } \\
\text { above } \\
\text { ece } \\
\text { level) }\end{array}$ & $\begin{array}{l}\text { Depth of } \\
\text { well } \\
\text { (foen below } \\
\text { land } \\
\text { surfece) }\end{array}$ & $\begin{array}{l}\text { Waler leved } \\
\text { (dato) }\end{array}$ & $\begin{array}{l}\text { Wower lovel } \\
\text { (feel below } \\
\text { land } \\
\text { surfice) }\end{array}$ & $\begin{array}{l}\text { Whiertovel } \\
\text { (altitude, } \\
\text { feet above } \\
\text { een level) }\end{array}$ \\
\hline 14N-06E-21 DAAA 4 & 354023096394804 & 322 VNSS & 832 & 28.0 & $09-21-92$ & 13.2 & 818.8 \\
\hline 14N-06E-21 DBD 1 & 354015096400301 & 322 VNSS & 839 & 133 & $03-19-90$ & 61.39 & 777.61 \\
\hline 14N-06E-22 BAC 2 & 354044096392301 & 322ADA & 835 & 155 & 09-21-92 & 65.75 & 769.25 \\
\hline 14N-06E-22 CAB 1 & 354022096392301 & 322ADA & 887 & 230 & $09-21-92$ & 54.52 & 832.50 \\
\hline 14N-06E-22 CAB 2 & 354022096392302 & 322 VNSS & 887 & 130.0 & $09-21-92$ & 105.0 & 782.0 \\
\hline 14N-06E-22 CAB 3 & 354022096392303 & 322 VNSS & 887 & 56.0 & $09-21-92$ & 33.2 & 853.8 \\
\hline 14N-06E-22 CAC 1 & 354016096392501 & 322 VNSS & 860 & 47.0 & $03-19-90$ & 21.4 & 838.6 \\
\hline 14N-06E-24 CCB 1 & 354009096373301 & 322ADA & 815 & 94.80 & $04-05-90$ & 48.47 & 766.53 \\
\hline $14 \mathrm{~N}-06 \mathrm{E}-26 \mathrm{AAC} 1$ & 353949096374901 & 322ADA & 810 & 115.50 & 04-05-90 & 81.37 & 728.63 \\
\hline 14N-06E-27 BBB 1 & 353957096394201 & 322 VNSS & 840 & 133 & $03-15-90$ & 23.87 & 816.13 \\
\hline 14N-06E-29 ABA 1 & 353958096411101 & 322VNSS & 780 & 87 & 04-03-90 & 17.45 & 762.55 \\
\hline 14N-06E-29 CBC 1 & 353923096414801 & 322 VNSS & 842 & 169 & $03-21-90$ & 36.13 & 805.87 \\
\hline 14N-06E-30 DDD 1 & 353907096415301 & $322 \mathrm{VNSS}$ & 820 & 148 & $03-21-90$ & 43.70 & 776.30 \\
\hline
\end{tabular}




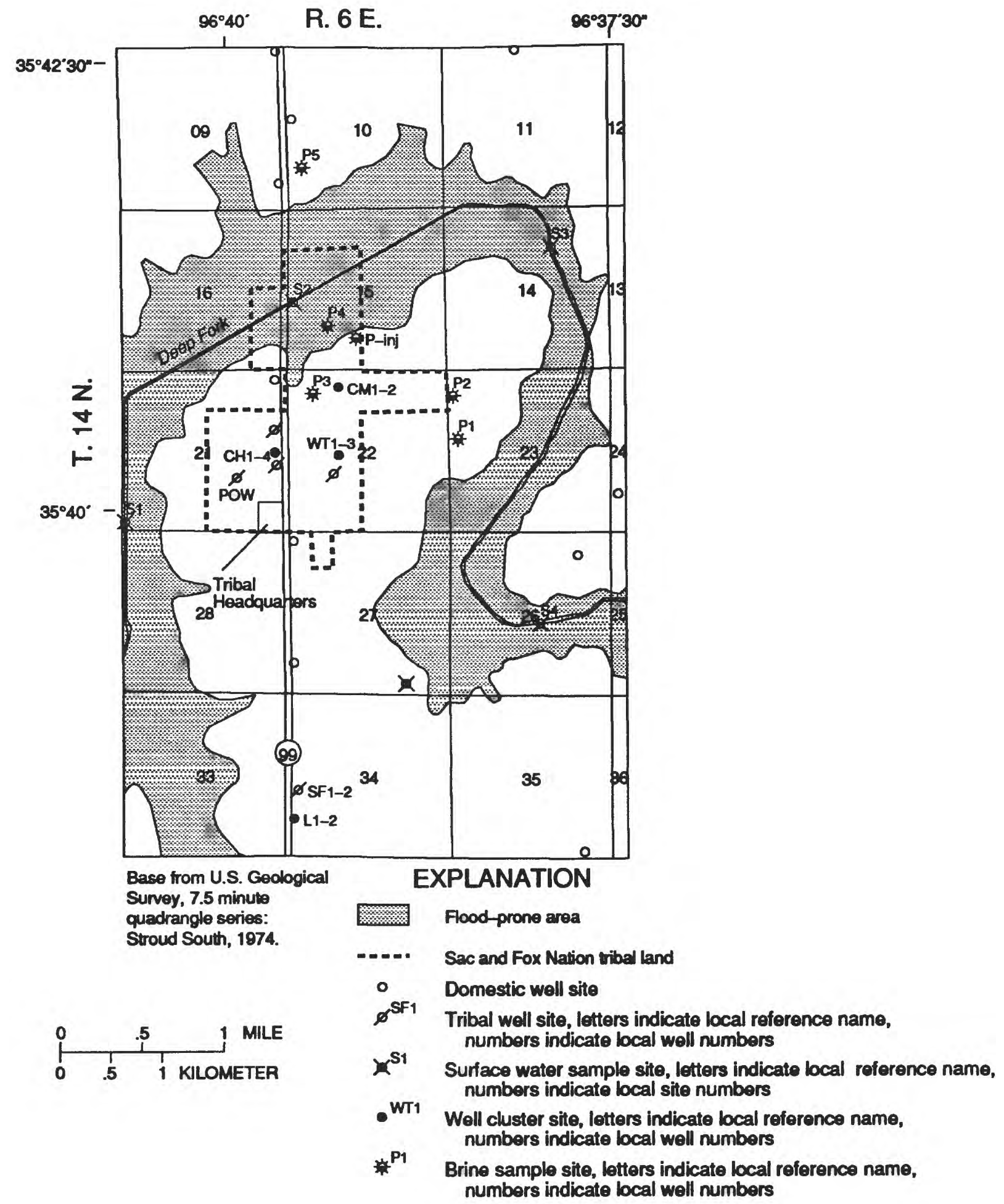

Figure 3. Map showing location of water-chemistry sampling sites on and adjacent to the Sac and Fox Nation tribal lands, eastern Lincoln County, Oklahoma. 
Table 2. Listing of analytical methods used at the National Water Quality Laboratory

[Parameter code, codes used to designate chemical constituents in the WATSTORB data base of the U.S. Geolopical Survey and in the STORET data base of the Environmental Protection Agency; g/mL, grams per milliliter, mg/h, milligrams per hiter, $\mu / \mathrm{L}$, micrograms per liter, AE, atomic emission spectrophotometry; ICP, inductively coupled plasma spectrophotometry; AA, atomic abeorption spectrophotometry; DCP, direct coupled plaema spectrophotometry; $\mathrm{pCi} / \mathrm{L}$ picocuries per liter]

\begin{tabular}{|c|c|}
\hline $\begin{array}{l}\text { Parameler } \\
\text { code }\end{array}$ & Parameter name, phase, and v \\
\hline 71820 & $\begin{array}{c}\text { Density, } \\
\mathrm{g} / \mathrm{mL} \text { at } 20 \text { degrees Celsius }\end{array}$ \\
\hline 70300 & $\begin{array}{c}\text { Solids, } \\
\text { Residure on evaporation at } \\
180 \text { degrees Celsius (mg/L) }\end{array}$ \\
\hline 00915 & $\begin{array}{l}\text { Calcium, dissolved } \\
\text { (mg/ as } \mathrm{Ca})\end{array}$ \\
\hline 00925 & $\begin{array}{l}\text { Magnesium, dissolved } \\
\text { (mg/L as } \mathbf{M g})\end{array}$ \\
\hline 00930 & $\begin{array}{l}\text { Sodium, dissolved } \\
\text { (mg/L as Na) }\end{array}$ \\
\hline 00935 & $\begin{array}{l}\text { Potassium, dissolved } \\
\text { (mg/L as } \mathrm{K})\end{array}$ \\
\hline 71870 & $\begin{array}{c}\text { Bromide, dissolvod } \\
(\mathrm{mg} / \mathrm{L} \text { 2s } \mathrm{Br})\end{array}$ \\
\hline 00940 & $\begin{array}{l}\text { Chloride, dissolved } \\
\text { (mg/L as } \mathrm{Cl} \text { ) }\end{array}$ \\
\hline 00950 & $\begin{array}{l}\text { Fluoride, diseolved } \\
\text { (mg/L as F) }\end{array}$ \\
\hline 71865 & $\begin{array}{l}\text { Iodide, dissolved } \\
\text { (mg/L as I) }\end{array}$ \\
\hline 00955 & $\begin{array}{l}\text { Silica, discolved } \\
(\mathrm{mg} / \mathrm{L} \text { as } \mathrm{Si})\end{array}$ \\
\hline 00945 & $\begin{array}{l}\text { Sulfate, dissolved } \\
\left(\mathrm{mg} / \mathrm{L} \text { as } \mathrm{SO}_{4}\right)\end{array}$ \\
\hline
\end{tabular}

\section{MAJOR CATIONS}

Mothod

\section{WATER PROPERTIKS}

MAJOR CATTONS

$$
\text { AE, ICP, direct }
$$

MAJOR ANIONS

$$
\text { Colorimetry, fucrescein, wuto }
$$

$$
A E, I C P \text {, direct }
$$

\section{TRACE ELEMENTS}

Arsenic, diesolvod ( $\mu g /$ as As)

$$
\text { ( } \mu \mathrm{g} / \mathrm{L} \text { as Ba) }
$$

01010

Beryllium, dissolved ( $\mu g / \mathrm{L}$ as $\mathrm{Be}$ )

01020

Boron, dissolved ( $\mu g / \mathrm{L}$ as B)

01025

Cadmium, diseolved

AE, DCP, direct $(\mu g / \mathrm{L}$ Cd) 
Table 2. Listing of analytical methods used at the National Water Quality Laboratory - Continued

\begin{tabular}{|c|c|c|c|}
\hline $\begin{array}{l}\text { Parameter } \\
\text { code }\end{array}$ & Paramoter name, phaee, and units & Mothod & $\begin{array}{l}\text { Mnimum } \\
\text { reporting } \\
\text { level }\end{array}$ \\
\hline 01035 & $\begin{array}{l}\text { Cobalt, dissolved } \\
(\mu g / L \text { as Co) }\end{array}$ & AE, ICP, direct & 3 \\
\hline 01040 & $\begin{array}{l}\text { Copper, dissolved } \\
(\mu \mathrm{g} / \mathrm{L}=\mathrm{Cu})\end{array}$ & $A E, I C P$, direct & 10 \\
\hline 01046 & $\begin{array}{l}\text { Iron, dissolved } \\
(\mu g / L \mathrm{Fe})\end{array}$ & $A E, I C P$, direct & 3 \\
\hline 01049 & $\begin{array}{l}\text { Lead, dissolved } \\
(\mu g / L \text { as } P b)\end{array}$ & AE, ICP, direct & 10 \\
\hline \multirow[t]{2}{*}{01130} & \multirow{2}{*}{$\begin{array}{l}\text { Lithium, dissolved } \\
\quad(\mu \& / L \text { Li) }\end{array}$} & AE, ICP, direct & 4 \\
\hline & & $\mathbf{A A}$, direct & 10 \\
\hline 01056 & $\begin{array}{l}\text { Manganese, dissolved } \\
(\mu \mathrm{g} / \mathrm{Ms} \mathrm{Mn})\end{array}$ & AE, ICP, direct & 1 \\
\hline 01060 & $\begin{array}{c}\text { Molybdenum, dissolved } \\
(\mu \mathrm{g} / \mathrm{L} \text { as } \mathrm{Mo})\end{array}$ & AE, ICP, direct & 10 \\
\hline 01065 & $\begin{array}{l}\text { Nickel, dissolved } \\
(\mu g / L \text { as Ni) }\end{array}$ & AE, ICP, direct & 10 \\
\hline 01145 & $\begin{array}{c}\text { Selenium, dissolved } \\
(\mu g / \mathrm{L}=\mathrm{Se})\end{array}$ & AA, hydride, auto & 1 \\
\hline 01075 & $\begin{array}{l}\text { Silver, dissolved } \\
\left(\mu g / \mathcal{L} \text { as } A_{8}\right)\end{array}$ & $A E, I C P$, direct & 1 \\
\hline 01080 & $\begin{array}{l}\text { Strontium, dissolved } \\
(\mu g / L \text { as })\end{array}$ & $\begin{array}{c}A E, I C P \text {, direct } \\
\mathbf{A} \text {, direct }\end{array}$ & $\begin{array}{l}0.5 \\
10\end{array}$ \\
\hline 01085 & $\begin{array}{l}\text { Venedium, dissolved } \\
(\mu \& / L=V)\end{array}$ & AE, ICP, direct & 6 \\
\hline 01090 & $\begin{array}{c}\text { Zinc, diseolved } \\
(\mu g / L=\mathrm{Zn})\end{array}$ & AE, ICP, direct & 3 \\
\hline \multicolumn{4}{|c|}{ RADIONUCLIDES } \\
\hline 09511 & $\begin{array}{l}\text { Radium 226, dissolved } \\
\text { (pCi/L as Rะ-226) }\end{array}$ & Radon emanation & 0.01 \\
\hline 82303 & $\begin{array}{l}\text { Radon 222, total } \\
\text { (pCi/L as Rn-222) }\end{array}$ & Liquid scintillation & 80 \\
\hline
\end{tabular}


Table 3. Listing of analytical mothods used at the National Wator Quality Laboratory for stable isotopes

\begin{tabular}{|c|c|c|c|}
\hline $\begin{array}{l}\text { Paramoler } \\
\text { cods }\end{array}$ & Paramoter namo, phase, and units & Method & $\begin{array}{l}\text { Preciolon } \\
\pm\end{array}$ \\
\hline \multicolumn{4}{|c|}{ STABLE ISOTOPES } \\
\hline 82082 & $\begin{array}{l}\text { Hydrogen-2/hydrogen-1, } \\
\text { in permil relative to SMOW }\end{array}$ & $\begin{array}{l}\text { Conversion to } \mathrm{H}_{2} \text { by reaction with } \\
\text { zinc metal, mass epectrometry }\end{array}$ & 1.5 \\
\hline 82085 & $\begin{array}{l}\text { Oxygen-18/oxygen-16, } \\
\text { in permil relative to SMOW }\end{array}$ & Equilibration with $\mathrm{CO}_{2}$, mase spectrometry & 0.10 \\
\hline
\end{tabular}

were collected during 1991 and 1992. These samples included stable isotopes and, if the specific conductance was not greater than 6,000 microsiemens per centimeter $(\mu \mathrm{S} / \mathrm{cm})$, the trace constituents. Appendixes 1 and 2 also list the quality-assurance samples collected during the study. Duplicate samples were taken for 10 percent of the samples from the well clusters. Three of the sites were resampled on different dates.

Eleven samples listed in appendixes 1 and 2 are analyses by the U.S. Geological Survey for other investigations. Ten samples dated in 1979 and 1980, are from Morton (1986) and were within the regional ground-water system investigation area of this report. One analysis, dated July 23, 1951, was from Laine and others (1951). It was from a Vamoosa Formation well in Stroud, SE 1/4 NW 1/4 SE 1/4 sec. 27, T. 15 N., $R$. $06 \mathrm{E}$., report as drilled to $500 \mathrm{ft}$ below land surface (Smith, 1942). The well had been a city water-supply well but has been unused since the water quality degraded. Other regional geochemical investigations of ground water in the Ada-Vamoosa aquifer are Bingham and Moore (1975) and D'Lugosz and others (1986).

The suggested maximum contaminant levels set by U.S. Environmental Protection Agency (1989) for chloride (250 milligrams per liter [mg/L]) and sulfate (250 $\mathrm{mg} / \mathrm{L}$ ) were used to separate fresh and saline water analyses in appendixes 1 and 2. Discussions of salinity in this report will follow the classification by Robinove and others (1958) where salinization is based on changes in total dissolved solids (TDS) (table 4). Water-quality sample, 14N-06E-27 BBB 1, is listed with the saline ground water (appendix 1) because the TDS is $1,230 \mathrm{mg} / \mathrm{L}$. Water-quality sample $14 \mathrm{~N}-06 \mathrm{E}-21$ DBD 1, dated March 29, 1990, has a TDS of 1,420 $\mathrm{mg} / \mathrm{L}$ but is listed with the fresh ground water (appendix 1) because later sampling of the well is thought to be more representative of the aquifer water quality.

Table 4. Salinity claseification baeod on TDS ranges, (Robinove and others, 1958)

\begin{tabular}{|c|c|c|c|}
\hline Class & \multicolumn{3}{|c|}{$\begin{array}{l}\text { Total Dissolved Solids } \\
\text { (milligrams per liter) }\end{array}$} \\
\hline Fresh & 0 & - & 1,000 \\
\hline Slightly saline & 1,000 & - & 3,000 \\
\hline Moderately saline & 3,000 & - & 10,000 \\
\hline Very saline & 10,000 & - & 35,000 \\
\hline Briny & greater than & & 35,000 \\
\hline
\end{tabular}

\section{Descriptlon of the Sampling Sites}

The tribal land is bounded on three sides by approximately $8 \mathrm{mi}$ of the river valley and associated wetlands (figs. 1 and 3). During periods of low flow, the principal component of surface-water flow is ground-water discharge to the surface-water system. The headwaters for the Deep Fork are $54 \mathrm{mi}$ to the west of tribal land on Permian formations. Four samples were collected from the river during an extended period of no rainfall in August 1991. The sample at the upstream site, 14N-06E-21 CCC 1 (site S1, appendix 2), was collected west of the Sac and Fox headquarters building. The remaining three surface-water sites were selected at $2-\mathrm{mi}$ intervals downstream. 
An inventory of existing domestic wells was conducted in T. 13 and 14 N., R. 06 E. located 39 wells (fig. 1). The information available on the construction of these wells is limited. Many of the wells are screened at the bottom of the borehole and sand packed throughout much of the well depth to increase well yield.

Four well clusters were constructed for waterquality sampling and water-level observations. The first three well clusters were $14 \mathrm{~N}-06 \mathrm{E}-21$ DAAA 1, 2, 3, and 4; 14N-06E-22 BAC 1 and 2; and $14 \mathrm{~N}-06 \mathrm{E}-22 \mathrm{CAB} 1,2,3$, and 4. For discussion purposes in this report sampled well clusters are named for a local geographical reference. The well number consists of the cluster name, a sequence number of the well in the cluster, and the formation from which the samples were collected. Wells in the first cluster in NE1/4 NE1/4 NE1/4 SE1/4 sec. 21, T. 14 N., R. 06 E., are near the tribal courthouse and will be referred to as $\mathrm{CH} 1, \mathrm{CH} 2, \mathrm{CH} 3$, and CH4. Wells in the second cluster in SW1/4 NE1/4 NW1/4 sec. 22, T. 14 N., R. 06 E., are near the tribal cemetery and will be referred to as CM1 and CM2. Wells in the third cluster, NW1/4 NE1/4 SW 1/4 sec. 22, T. 14 N., R. 06 E., are near the tribal watertower and will be referred to as WT1, WT2, and WT3. The formations are labeled Vanoss = VS, Ada = AD, Vamoosa = VM, and Vamoosa/Tallant = VM/T.

Each well cluster consists of 2-4 wells drilled approximately $10 \mathrm{ft}$ apart and constructed to sample and observe selected zones. The locations of the clusters were selected to sample areas of suspected saltwater encroachment or areas where additional information was needed.

CH1 was first drilled to $41 \mathrm{ft}$ and a water-quality sample from the shallowest water bearing sandstone in the Vanoss Formation (fig. 4) was taken through a submersible pump in the open borehole. CH1 was then drilled to $248 \mathrm{ft}$ (fig. 4), deep enough to sample a saline-water-bearing horizon in the Vamoosa Formation. An inflatable packer and screen assembly were placed on the drill pipe and then lowered into the borehole. The bottom of the packer was placed at $230 \mathrm{ft}$. A submersible pump was lowered inside the drill pipe through which the water sample was collected. The water level above the packer and outside the drill pipe was monitored with an electrical water-level meter during sampling to assure the packer seal. After sampling, $\mathrm{CH} 1$ was plugged to $108 \mathrm{ft}$ with cement grout and bentonite to seal off the saline-water-bearing hori- zon. The well was then drilled to $190 \mathrm{ft}$ and was completed using polyvinyl chloride (PVC) plastic casing, screens, and sand pack but a water-quality sample from this zone was not possible because of cement problems.

CM1 was drilled to $262 \mathrm{ft}$ (fig. 5), into stratigraphically equivalent sandstones as CH1 in the Vamoosa Formation (fig. 4). A water sample was collected with an inflatable packer and screen assembly through a submersible pump like $\mathrm{CH} 1$. The bottom of the packer was at $190 \mathrm{ft}$. CM1 was completely sealed, after sampling, with cement and not completed in a shallower freshwater zone.

WT1 was drilled to $302 \mathrm{ft}$ (fig. 6), into stratigraphically equivalent sandstones as CH1 in the Vamoosa Formation (fig. 4). A water sample was collected with an inflatable packer and screen assembly through a submersible pump like CH1. The bottom of the packer was at $270 \mathrm{ft}$. WT1 was plugged, after sampling, with cement grout and bentonite to seal off the saline-water bearing horizon to $230 \mathrm{ft}$. The well was completed in a shallower single freshwater zone in the Ada Formation (fig. 6) using PVC casing, screens, and sand pack.

Subsequent wells in each well cluster were completed by isolating selected sandstones using PVC casing, screens, and sand pack. The sandstones were selected from natural gamma-ray borehole geophysical logs from the test well in each cluster. The annulus of all cluster wells were sealed above the sand pack with bentonite or cement to prevent invasion of the selected zone by water from shallower sandstones. The subsequent wells in each cluster were logged inside the PVC casing with natural gamma-ray logs to confirm the completion of these wells in the selected sandstones and to evaluate the extent of lateral change of the sandstone units. The wells in each cluster were drilled a minimum of $10 \mathrm{ft}$ from the nearest well to ensure integrity between wells.

The two wells constructed on private land near where the tribe has leased water rights, $14 \mathrm{~N}-06 \mathrm{E}-34$ CBC 1 and 2, (referred to as L1 and L2) were drilled to $300 \mathrm{ft}$ and $560 \mathrm{ft}$. The $300-\mathrm{ft}$ well, in the Vamoosa Formation, was constructed for a water-level observation well and was not sampled. The 560-ft well, L2 (fig. 7), was drilled into the shallowest sandstones containing saline water and was screened from 500 to 560 ft. Two water-quality samples, a field and a replicate sample, were obtained from the well. The two sand- 


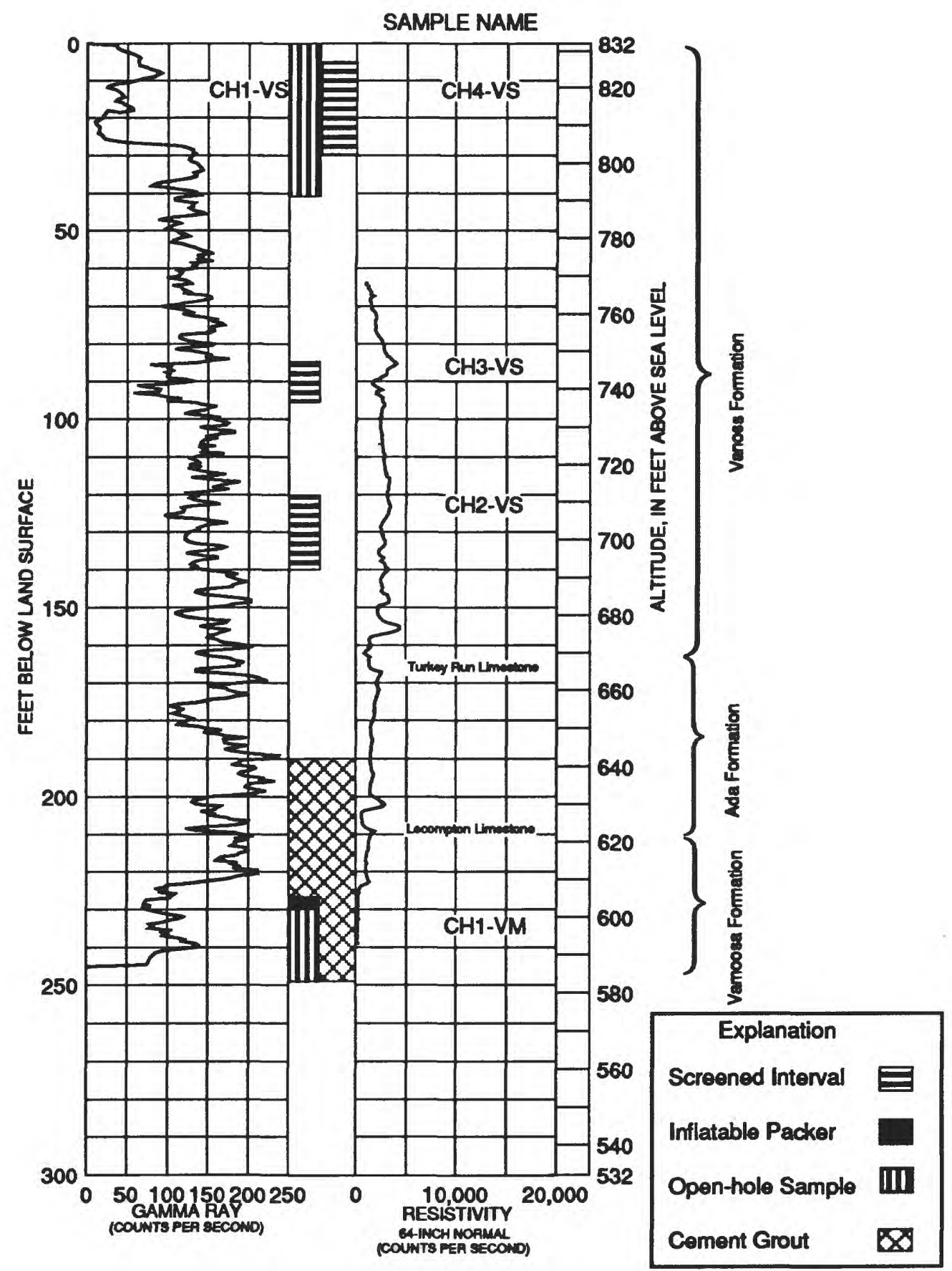

Flgure 4. Geophysical logs from borehole CH1, sample interval for CH1-VS and CH1-VM, and screened interval for samples CH2-VS, CH3-VS, and CH4-VS, in boreholes CH2, CH3, and CH4; 14N-06E-21 DAAA; eastern Lincoln County, Oklahoma. 


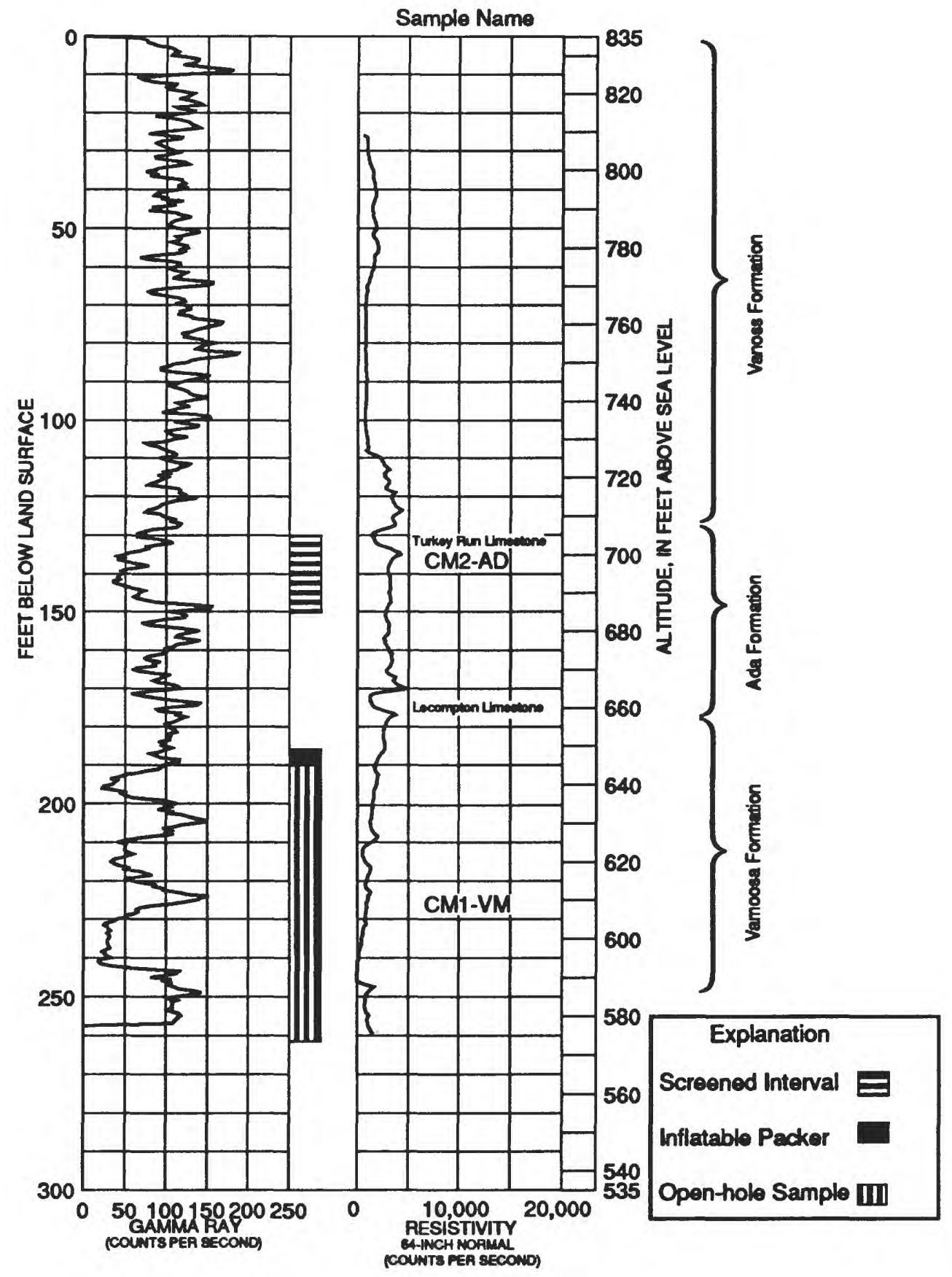

Figure 5. Geophysical logs from borehole CM1, sample interval for CM1-VM, and screened interval for sample CM2-AD, in borehole CM2; 14N-06E-22 BAC; eastern Lincoln County, Oklahoma. 


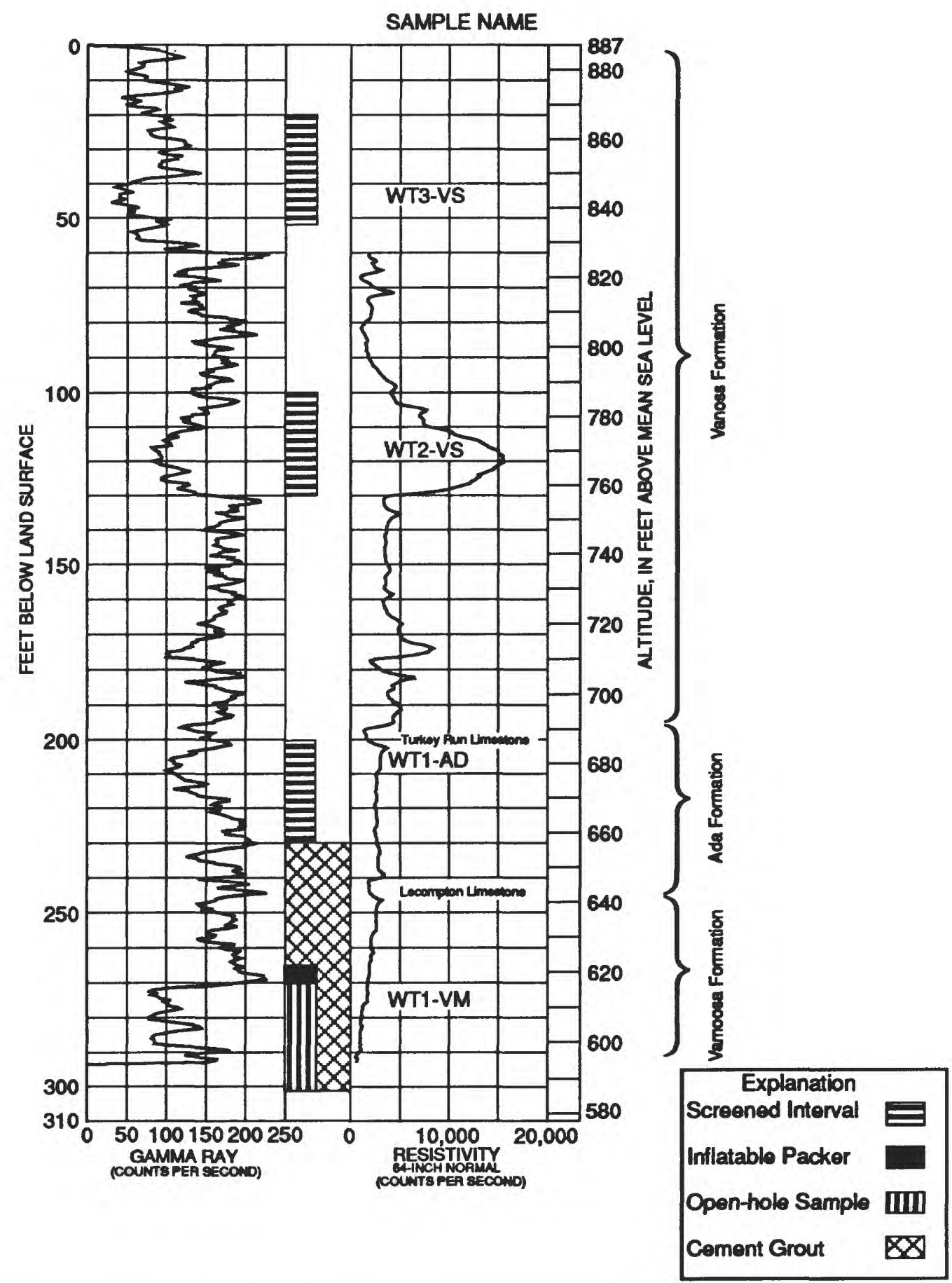

Flgure 6. Geophysical logs from borehole WT1, screened and sample interval for WT1-AD and WT1-VM, and screened interval for samples WT2-VS and WT3-VS, in boreholes WT2 and WT3; 14N-06E-22 CAB; eastern Lincoln County, Oklahoma. 


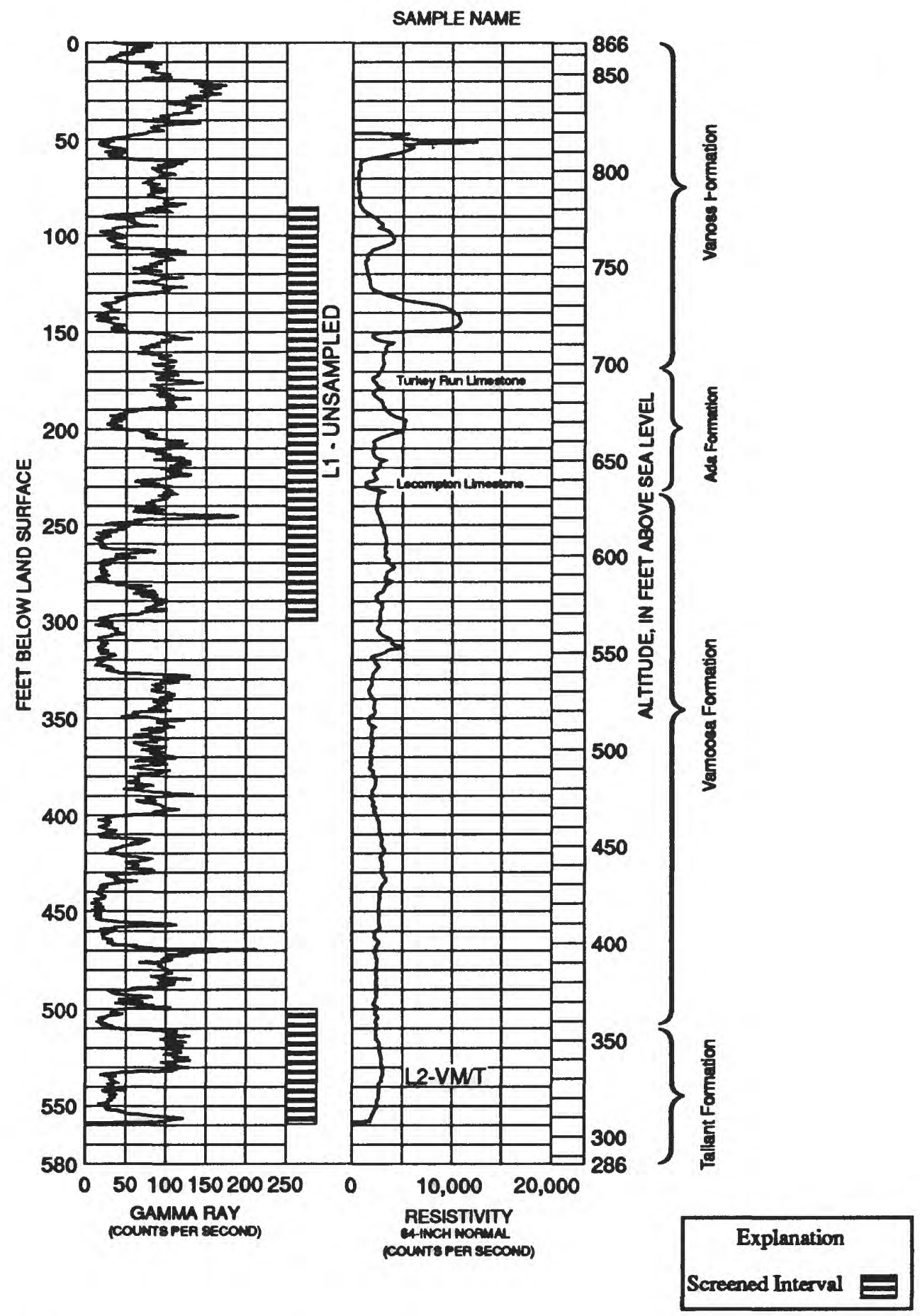

Figure 7. Geophysical logs from borehole L2, screened interval for L2-VM/T, and screened interval in borehole L1; 14N-06E-34 CBC; eastern Lincoln County, Oklahoma. 
stone units supplying this well probably are the lowest sandstone of the Vamoosa Formation and the upper sandstone of the underlying Tallant Formation of the Missourian Series below the Vamoosa Formation (fig. 7). Borehole geophysical logs from oil wells were used to select the depth to drill in this well.

The tribal water-supply wells are $14 \mathrm{~N}-06 \mathrm{E}-34$ CBB 1 (north well) and 2 (south well). These wells were screened to $260 \mathrm{ft}$ and $270 \mathrm{ft}$, respectively, in the Vamoosa Formation. The wells are $246 \mathrm{ft}$ apart and $1,144 \mathrm{ft}$ from L1. For discussion purposes these wells will be referred to as SF1 (north well) and SF2 (south well).

All oil production on the Sac and Fox Nation tribal land is from the Prue sand at approximately $3,000 \mathrm{ft}$ below land surface. The Prue sand is an informal member of the Senora Formation of the Cabaniss Group of the Desmoinesian Series of the Pennsylvanian (fig. 2). Six brine samples from the oil production were collected in February 1992. Five samples were taken at well-head pumping units that were on or adjacent to tribal land. In this report these wells will be referred to as P1, P2, P3, P4, and P5 (fig. 3). One sample was collected from the waterflood injection system at the pressure pump on the Sac and Fox Prue Sand Waterflood Unit in NE1/2 SE1/4 SW1/4 sec. 15, T. 14 N., R. 06 E. and will be referred to as P-inj (fig. 3).

The five samples from the producing pumping units are water taken directly from the Prue sand and represent the present formation water. The injectionwater sample, $P$-inj, represents the water composition that is injected back into the Prue sand by the waterflood operations. The injection water is composed of formation water from several producing wells, any make-up water needed for additional volume into the injection system, and chemicals that are added to the injection water to reduce problems from sulfate precipitates and paraffins. The volume of make-up water added to the imjection system at the beginning of a waterflood is much larger than the volume needed later in the waterflood. The original Prue brine composition and its variance across secs. $15,16,21$, and 22 , T. 14 N., R. 06 E. are not known. Changes from the original brine composition would have occurred as the waterflood operations were injecting the langest amount of make-up water. No make-up water is being added currently to the injection systems. The make-up water was reportedly from the Tallant Formation (Canard, 1989). The lower sandstone in L2 (from 530 $-560 \mathrm{ft}$ ) is in the Tallant Formation.

\section{Ceohydrologic Investigation Methods}

The well clusters were logged using U.S. Geological Survey borehole geophysical logging equipment. The logs were interpreted to correlate between the geologic units, to obtain a qualitative evaluation of the water resistivity in the units, and to evaluate the thickness and placement of the sandstones within the aquifer system. The borehole geophysical logs from the deepest wells in each cluster are shown in figures 4-7 and the well locations are noted on figures 1 and 3. Sampling intervals for each well in the cluster are indicated on the logs. U.S. Geological Survey logging equipment recordings were taken in counts per second (cps). Complete cores were taken from two test wells, CH1 and WT1, to correlate lithology with the geophysical logs.

The regional strike and dip were determined from cluster wells CH1, CM1, and WT1. The Turkey Run Limestone marker, at $167 \mathrm{ft}$ in $\mathrm{CH} 1$, was used in the calculation. The strike was $\mathrm{N} 22^{\circ} \mathrm{W}$ and dip was $0.8^{\circ} \mathrm{W}$. The strike of the faults in the region are generally $\mathrm{N} 20^{\circ} \mathrm{W}$. Each of the domestic wells was evaluated using the regional strike and dip to determine if the well had penetrated the Ada Formation or had only been drilled into the Vanoss Formation (table 1).

The gamma-ray logs on figures 4-6 indicate the thickness and position of sandstones and shales in the test hole. Sandstones, such as 10-27 ft in CH1 (fig. 4), have $10-100 \mathrm{cps}$ on the gamma-ray logs. Shales, 130 $170 \mathrm{ft}$ and $250-270 \mathrm{ft}$ in WT1 (fig. 6), have 150-240 cps. Shaley sandstones and limestones have 100-150 cps on the gamma-ray logs.

\section{FRESHWATER RESOURCES}

\section{Surface-Water Geochemlstry In the Study Area}

Surface-water samples (S1, S2, S3, and S4), in appendix 2, were collected in August 1991 during a period of low flow when the Deep Fork receives water from Lake Arcadia near Oklahoma City and from the lower Permian formations downstream from the lake and west of the study area. These samples contain approximately equal concentrations of sodium and calcium plus magnesium (appendix 2 ). The alkalinity (as calcium carbonate) from these surface-water sam- 
ples is approximately twice the chloride concentration (appendix 2). They contain measurable dissolved-oxygen concentrations and have TDS less than $600 \mathrm{mg} / \mathrm{L}$.

\section{Fresh Ground-Water Geochemlstry In the Study Area}

Fresh ground water in the Vanoss Formation occurs in recharge areas where the water has not been in the ground-water system long and water-rock interaction is controlled by time. Shallow samples from the Vanoss Formation, such as CH1-VS, CH4-VS, WT2VS, and WT3-VS, generally are composed of sodium bicarbonate or sodium-calcium-magnesium bicarbonate water. Water from the Vanoss Formation contains measurable dissolved-oxygen concentrations throughout the area, as shown by measurements made while sampling (appendix 1). Fresh ground water from the Ada and Vamoosa Formations has TDS less than 600 $\mathrm{mg} / \mathrm{L}$ and is sodium bicarbonate or sodium-calciummagnesium bicarbonate water. The one dissolved oxygen measurement for a sample from the Vamoosa Formation, SF2-VM, showed measurable dissolved oxygen.

\section{Geology of the Freshwater Aqulfers}

The Vamoosa Formation is composed of lenticular sandstones and silty shales (Oakes, 1959). The sandstones are generally well-cemented and medium to fine grained. The base of the Formation in Creek County (fig. 1) is described by Oakes (1959) as a conglomerate. Oakes (1959) described a massive sandstone section in the lower half of the Vamoosa Formation in T. 14 N., R. 07 E. similar to the section seen on the $\log$ from $400 \mathrm{ft}$ to $470 \mathrm{ft}$ in borehole $\mathrm{L2}$ (fig. 7). The upper sandstones of the Vamoosa Formation present in wells CH1, CM1, and WT1 (figs. 4-6) are in borehole L2 from $245 \mathrm{ft}$ to $326 \mathrm{ft}$ (fig. 7). The top of the formation is placed at the base of the Lecompton Limestone (figs. 4-7). The Vamoosa Formation is approximately $250 \mathrm{ft}$ thick in the study area.

The Ada Formation as described by Oakes (1959) is approximately $40 \mathrm{ft}$ thick and contains two limestone beds, the Lecompton Limestone at the base and the Turkey Run Limestone at the top. The presence of the Lecompton Limestone was confirmed in $T$. 13 N., R. 07 E. by Ries (1954), but he reported the Turkey Run Limestone is absent in Okfuskee County (fig. 1). The two limestones are tentatively identified in the study area by projecting the general regional dip (Oakes, 1959) of $70 \mathrm{ft}$ per mile or $0.8^{\circ}$ to the west from the Lecompton outcrops, secs. 19 and 31, T. 14 N., R. 07 E., to the cluster well WT1 (fig. 6). Two thin limestones were present in the well core at depths of 195 and $242 \mathrm{ft}$ separated by $40 \mathrm{ft}$ of shale and sandstone. Similar limestones also can be identified in the remaining well-cluster logs in figures 4,5 , and 7. A water-bearing sandstone is present at $195 \mathrm{ft}$ between the Turkey Run and Lecompton Limestones (fig. 7) in borehole L2.

The Vanoss Formation overlies the Ada Formation and forms the hills above the Deep Fork valley on tribal land. Cores taken from the well clusters contained very fine- to fine-grained sandstones that were moderately to well cemented and were interbedded with red and gray shales. A complete stratigraphic section of the Vanoss Formation is not present on tribal land. Borehole WT1 penetrated $195 \mathrm{ft}$ of the Vanoss Formation.

The gamma-ray logs indicate the sandstones in the Vanoss, Ada, and upper Vamoosa Formations, on the tribal land, are thinner than the shales. Hydraulic conductivity in shales is much less than in sandstones. Volumetric rate of ground-water movement is smaller through shales and is greater in sandstones.

\section{Hydrology of the Freshwater Aquifers}

Hydrologic data for the aquifers are published in Hart (1974), Bingham and Moore (1975), Bingham and Bergman (1980), D'Lugosz and others (1986), and Morton (1986). Recharge to the ground-water system occurs where sandstones outcrop on topographically higher areas. The Vanoss and Ada Formations are unconfined and semiconfined aquifers in the study area. The Vamoosa Formation is a confined aquifer in the study area but is at the surface in Creek County, 2 $\mathrm{mi}$ to the east of the Sac and Fox Nation (Oakes, 1959). Morton concluded the gradient of the water table in the unconfined areas of the aquifer was locally toward gaining streams (Morton, 1986, Plate 1, map A). He also stated that in the confined part of the aquifer the potentiometric surface followed the regional dip to the west. Therefore, recharge to the confined part of the aquifer is east of the tribal land.

Discharge from the ground-water system occurs where sandstones outcrop near gaining streams such 
as the Deep Fork (Morton, 1986) and its associated wetlands. Stream discharge measurements made at the time of sampling during a low-flow period indicated the river was gaining 1.5 cubic feet per second for each subsequent mile downstream.

\section{Base of Fresh Ground Water}

Fresh ground water is underlain by briny water because TDS and salinity generally increase with greater depths. The depth to the shallow brine varies because of local conditions such as the amount of precipitation, the thickness of the sandstones in the aquifers, the velocity and direction of ground-water movement, the length of the flow paths from the area of recharge to the discharge area, and the amount of ground water withdrawn by wells. Locally the shallow brine and the fresh ground-water lenses would eventually reach chemical and hydrologic equilibrium if recharge equals discharge and remains constant. In recharge areas and where the sandstone sequence is thick (Morton, 1986) the upper boundary of the shallow brine is deeper and the saturated thickness of fresh ground water above it is greater. Conversely, in discharge areas and where siltstone and shale sequences are thicker, the shallow brine is closer to the land surface and the fresh ground-water lens is not well developed.

The altitude of the base of fresh water was evaluated from borehole geophysical logs of oil wells. No data were available on many of the wells because of the deep surface casing or the well interval was not logged. Borehole geophysical logs are continuous recorded measurements of physical properties of the rocks through which the hole was drilled, the fluid in the rock, and the fluid in the borehole. Many of the oil wells on tribal land were drilled and producing before borehole geophysical logging became common practice. $\log$ data used to evaluate the altitude of the base of fresh ground water are from oil wells drilled beginning in 1953 and 1954 on tribal land, after the waterflooding started in the Sac and Fox Prue Sand Units. Log data used in the evaluation and not on tribal land or in the Sac and Fox Prue Sand Units are from wells beginning in 1951. During this time 16 in. and 64 in. normal-resistivity and lateral-resistivity logging was common practice. The 16 in. (short normal) resistivity $\log$ only investigates near the borehole in the zone invaded by drilling mud. The 64 in. (long normal) and the lateral-resistivity logs investigate the invaded zone and the undisturbed formation (Keys, 1988).

Borehole geophysical logs are used to evaluate the economic potential of oil wells and so the potential producing zones are logged with the greatest care. Since the shallow freshwater zones are not of economic interest, many logs do not record the shallow zones. Most of the oil wells for which data are available are recorded from the base of the surface casing to the total depth of the well. The length of surface casing required in well construction is regulated by the Oklahoma Corporation Commission and the requirements have changed with time. The more recent wells have surface casing set to greater depths than do the older wells.

Drilling practices are fairly constant in central Oklahoma, where sodium bentonite is used as the drilling fluid and the lithologic sequence in the formations is regionally constant. The well clusters and the early oil wells were drilled with native mud that forms in the borehole in the saturated zone.

Since fresh water has a greater resistance to the flow of electrons than brine water, borehole resistivity logs will shift to higher values as the TDS in the water decrease. Logs, however, do not respond only to changes in water quality. Keys and MacCary (1973) pointed out that resistivity logs measure changes in formation fluid, borehole fluid, and formation lithology. Log response then is a crude measure of changes in water quality.

Figure 8 shows the altitude of the base of fresh ground water presented in feet above sea level. The map illustrates the lower surface of fresh ground water. The data for figure 8 are given in appendix 3. A minimum resistivity value of $10 \mathrm{ohm}$-meters in a sandstone was chosen to represent the change from fresh water to saline water. The resistivity value selected is an arbitrary selection only for mapping purposes.

Figure 9 shows sections from near the Deep Fork on the east, across a topographically high area to the river or the wetlands to the west. The sections show the land surface and the altitude of the base of fresh ground water in figure 8.

The altitude of the base of fresh water is nearer the land surface along the river and the wetlands than in the adjoining areas that are topographically higher 

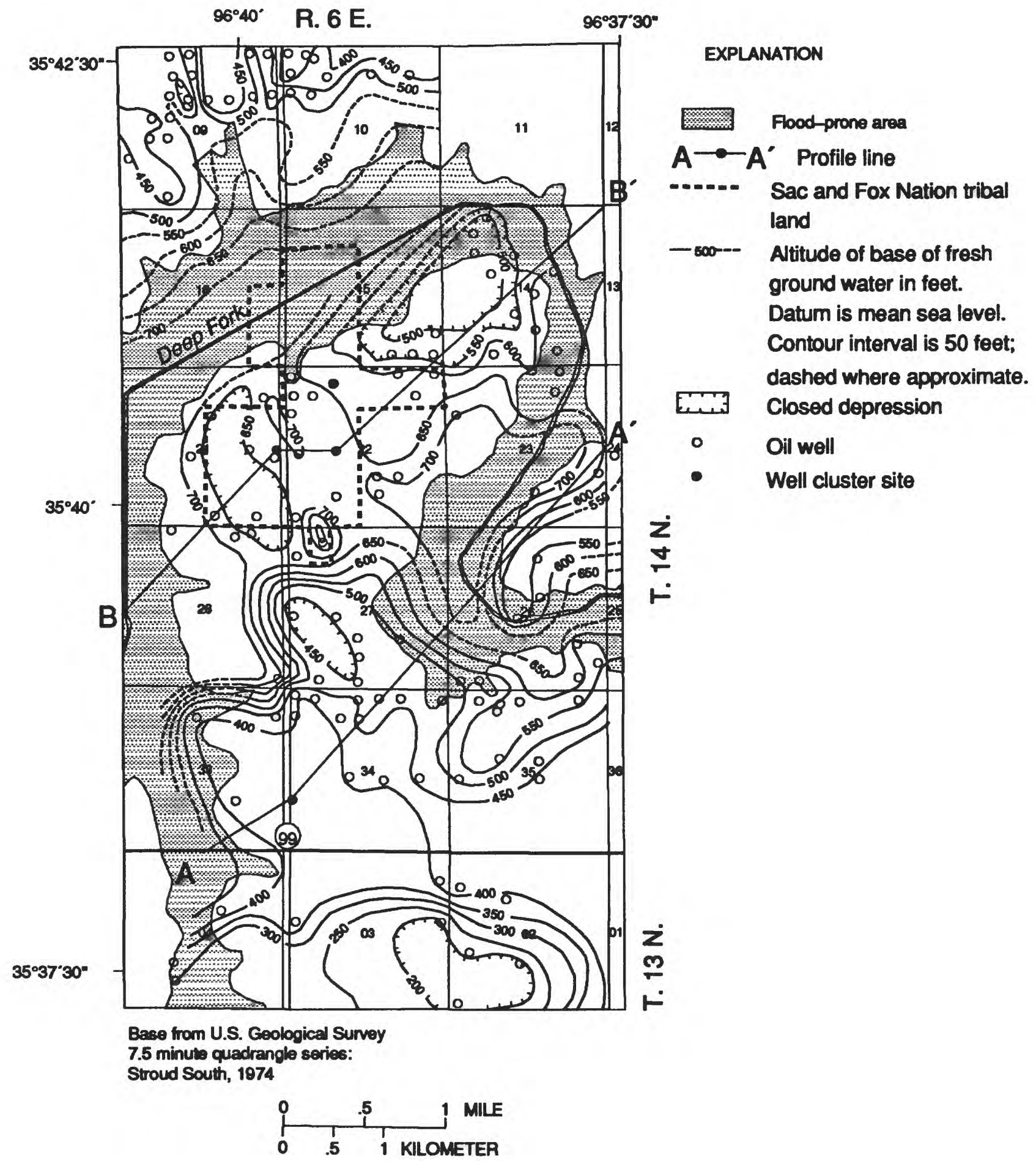

Figure 8. Map of the altitude of the base of fresh ground water, from wells drilled between 1951-95, eastern Lincoln County, Oklahoma. 

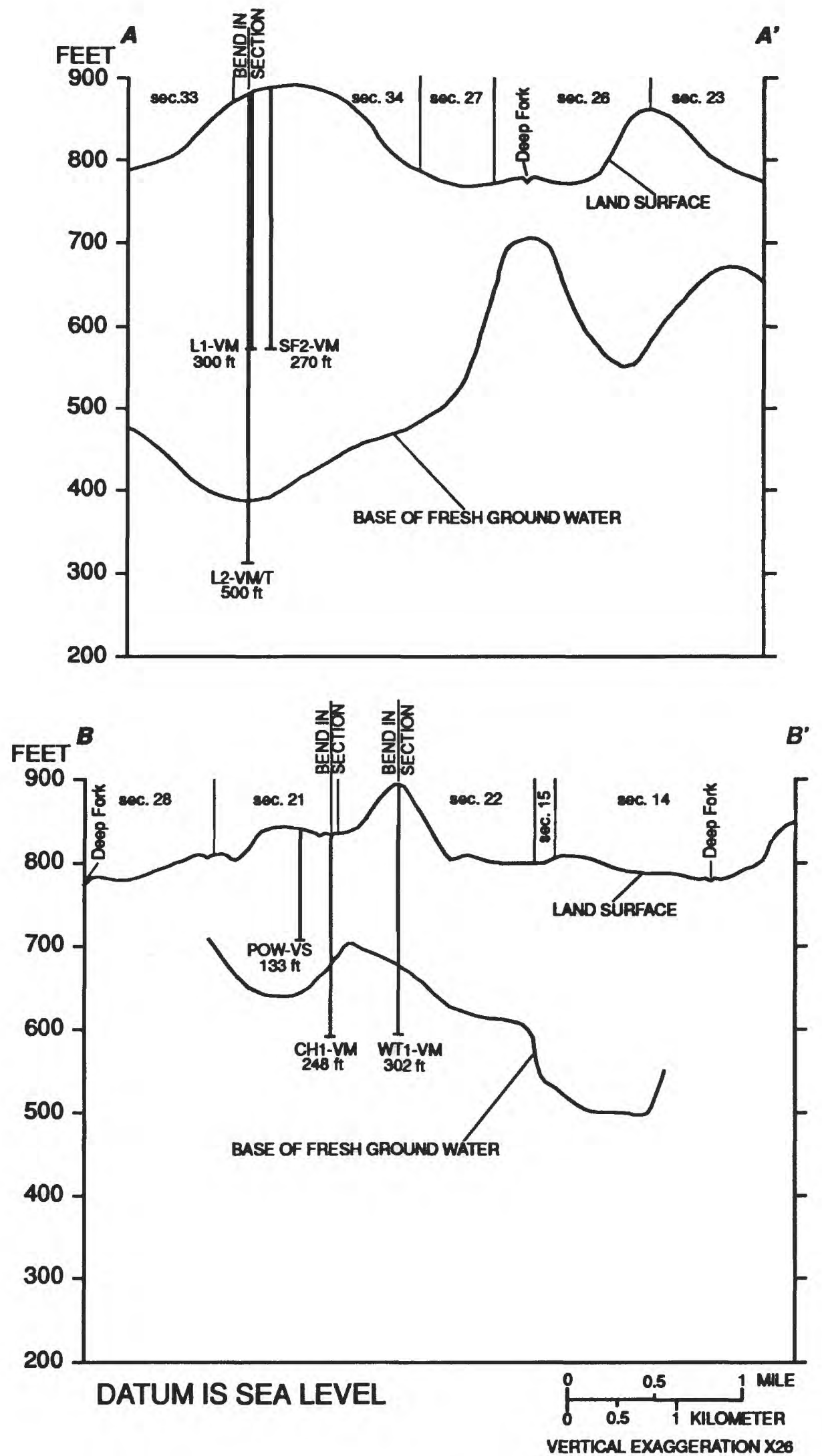

Figure 9. Generalized hydrologic sections $A-A^{\prime}$ and B-B' showing relation between land surface and base of fresh ground water in the Ada-Vamoosa aquifer, 1951-95, eastern Lincoln County, Oklahoma. 
(figs. 8 and 9). In section $A-A^{\prime}$, the altitude of the base of fresh ground water is generally low beneath the topographically high areas such as secs. 26 and 34, T. 14 N., R. $06 \mathrm{E}$. The altitude of the base of fresh ground water near the Deep Fork in section $A-A^{\prime}$, is nearer the land surface at $700 \mathrm{ft}$. Sandstones are present throughout the Vanoss and Ada Formations in L2 (fig. 7 ) in sec. 34 .

The altitude of the base of fresh ground water in section B-B' (fig. 9) under the W1/2 sec. 22, T. 14 N.,R. $06 \mathrm{E}$. is generally near $700 \mathrm{ft}$, which is nearer the land surface beneath the topographically high area than on section $A-A^{\prime}$. In figure 8 the area where the base of fresh ground water is near the land surface includes the SE1/4 sec. 22, T. 14 N., R. 06 E. and extends into the E1/2 NE1/4 sec. 21, T. 14 N., R. 06 E. and NE1/4 NW1/4 NW1/4 sec. 27, T. 14 N., R. 06 E. West of this area in the W1/2 E1/2 sec. $21, T .14$ N., R. $06 \mathrm{E}$. (fig. 8) the altitude of the base of fresh ground water is lower, as would be expected based on land surface. $A$ lens of fresh ground water has developed in the W1/2 sec. 14, T. 14 N., R. 06 E., the SE1/4 sec. 15, T. 14 N., R. 06 E., and the NE1/4 sec. 22, T. 14 N., R. 06 E. Shales and siltstones dominate most of the Vanoss and Ada Formations in CH1, CM1, and WT1 (figs. 4-6).

The altitude of the base of fresh ground water (fig. 8) determined from borehole geophysical logs was generally comparable to the fresh and saline ground water samples from the well clusters (appendix 1). The difference in the altitude of the base of fresh ground water of the two methods ranged from 23 to 70 $\mathrm{ft}$ and is expected because the two methods are sensitive to different variables. The altitude of the base of fresh ground water from borehole geophysical logs (fig. 8) near the $\mathrm{CH}$ well cluster was about $680 \mathrm{ft}$. Freshwater samples (appendix 1) taken from the $\mathbf{C H}$ well cluster were CH1-VS and CH4-VS (fig. 4) at an altitude of $790 \mathrm{ft}$. Shallowest saline water sample (appendix 1) taken from the $\mathbf{C H}$ well cluster was moderately saline from CH3-VS at an altitude of $750 \mathrm{ft}$. The altitude of the base of fresh ground water determined by the water-quality samples in the $\mathrm{CH}$ well cluster was between $750 \mathrm{ft}$ and $790 \mathrm{ft}$.

The altitude of the base of fresh ground water (fig. 8) near the CM well cluster was about $640 \mathrm{ft}$. Fresh water was not sampled in the CM well cluster (appendix 1). Slightly saline water was from CM2-AD (fig. 5). The altitude of the base of fresh ground water determined by the water-quality samples was above $705 \mathrm{ft}$.

The altitude of the base of fresh ground water (fig. 8) near the WT well cluster was about $680 \mathrm{ft}$. Freshwater samples (appendix 1) taken from the WT well cluster were WT1-AD, WT2-VS, and WT3-VS (fig. 6). Shallowest saline water sample taken from the WT well cluster was briny water (table 4) from WT1VM. The altitude of the base of fresh ground water determined by the water-quality samples in the WT well cluster was between $657 \mathrm{ft}$ and $618 \mathrm{ft}$.

Borehole geophysical logs and water-quality samples indicate the fresh ground water was better developed near sec. 34, T. 14 N., R. 06 E., where the tribe has leased water rights, than near the tribal land. The altitude of the base of fresh ground water near SF1 and SF2 in figure 8 was about $400 \mathrm{ft}$. Fresh water was sampled from SF1 and SF2 (appendix 1), which were screened in the same interval as L1 (fig. 7) to an altitude of about $570 \mathrm{ft}$. Briny water was sampled from L2 (fig. 7), which was screened to an altitude of about $385 \mathrm{ft}$. The altitude of the base of fresh ground water from the water-quality samples in sec. $34, T .14$ N., $R$. $06 \mathrm{E}$. was between $385 \mathrm{ft}$ and $570 \mathrm{ft}$.

Water-quality sampling and borehole geophysical data indicate the potential for fresh ground water on tribal land generally is greatest in the Vanoss Formation, in the SE1/4 sec. 21, T. 14 N., R. 06 E. and in the NE1/4 sec. 22, T. 14 N., R. 06 E. These locations avoid the flood-prone areas and borehole geophysical resistivity logs indicate the altitude of the base of fresh ground water is below $650 \mathrm{ft}$ (fig. 8). Fresh ground water samples were CH1-VS, CH4-VS, WT2-VS, WT3-VS, and WT1-AD. Domestic wells listed in appendix 1, which are on or near tribal land, that produce fresh ground water are completed in the Vanoss Formation.

Conditions are more favorable for placement of fresh ground water wells near SF1 and SF2 in section 34 , where the tribe has leased water rights, than on tribal land in secs. 15, 16, 21, and 22, T. 14 N., R. 06 E. General water quality near the Deep Fork is poor because the gradient of the water table in the unconfined part of the aquifer is locally toward the river (Morton, 1986) and not circulating into the confined beds of the aquifer. Sandstones comprise only 6 percent of the stratigraphic section in borehole CH1 (fig. 4), 9 percent of CM1 (fig. 5), and 20 percent of WT1 (fig. 6). L2 (fig. 7) has 42 percent sandstone present in the fresh ground water interval from 45-330 ft. Thick 
shale beds in the Vanoss Formation at CH1, CM1, and WT1 (figs. 4-6) impede vertical recharge near these wells. Thin shale beds logged in L2 in the Vanoss and Ada Formations provide less impedance to vertical recharge near SF1 and SF2.

\section{SALINE WATER}

Ground water from the Ada and Vamoosa Formations, in the area where the altitude of the base of fresh ground water is near the surface, in the W1/2 sec. 22, T. 14 N., R. 06 E., have high sodium chloride (NaCl) and sodium sulfate $\left(\mathrm{Na}_{2} \mathrm{SO}_{4}\right)$ concentrations on tribal land (appendix 1). Water-quality samples CH2-VS, CH3-VS, CM2-AD, CH1-VM, CM1-VM, WT1-VM, and L2-VM/T have chloride or sulfate concentrations greater than $250 \mathrm{mg} / \mathrm{L}$.

\section{Potentlal Sources of Brine}

Two possible sources for sodium chloride and sodium sulfate are shallow brines and deep brines from oil production at $3,000 \mathrm{ft}$. The Deep Fork was not considered as a possible source of salinity because the water is sodium-calcium-magnesium bicarbonate and not concentrated enough to create the sodium chloride or sodium sulfate water in the Vanoss, Ada, and Vamoosa Formations. Shallow brines and the brines from oil production are discussed as potential sources of salinity by Morton (1986) and Richter and Kreitler (1991).

Shallow brine composition in the study area is unknown and may vary. CH1-VM, WT1-VM, and L2-VM/T may represent shallow brine compositions. Probable sources of shallow brine in the study area are: 1) solution of minerals as fresh water moves through the aquifer and 2) residual brine deposited with the sediment (Richter and Kreitler, 1991). There are no salt or gypsum beds in the Vanoss, Ada, or Vamoosa Formations. Salt and gypsum were not found in the cores from CM1 and WT1. Salt and gypsum may be present, however, as nodules and finely disseminated minerals in the formations that could create the sodium chloride and sodium sulfate in the waterquality samples.

It can be assumed that the regional aquifer that now contains fresh ground water once was filled with seawater at the time of deposition (Parkhurst and other, 1992; Richter and Kreitler, 1991). Over time, the freshwater flow system has flushed out or removed most of the brine. Residual brine can remain in sandstones and shales that have not been diluted by freshwater circulation. Sandstones overlain by or enclosed in thick clay and shale sequences are likely to be somewhat isolated from the flow system and retain some of the residual brine. The Vanoss Formation intersected by WT2 (fig. 6) has about $18 \mathrm{ft}$ of shaley sandstone enclosed in $190 \mathrm{ft}$ of clay and shale, and WT2-VS has a TDS of $774 \mathrm{mg} / \mathrm{L}$. The Vanoss Formation intersected by CH3 (fig. 4) has about $5 \mathrm{ft}$ of shaley sandstone enclosed in $200 \mathrm{ft}$ of clay and shale and CH3-VS has a TDS of $3,840 \mathrm{mg} / \mathrm{L}$. This suggests higher TDS values maybe expected from thin shaley sandstones. The Vanoss, Ada, and upper Vamoosa Formations intersected by L2 (fig. 7) have 4 sandstone units that total $55 \mathrm{ft}$ in $195 \mathrm{ft}$ of clay and shale. Each of these sandstones are 10 to $20 \mathrm{ft}$ thick. Sample SF2VM is from the same sandstone interval, shown as L1unsampled (fig. 7) and has a TDS of $254 \mathrm{mg} / \mathrm{L}$. Multiple sandstones in the interval probably improve freshwater circulation. Borehole geophysical logs suggest the sandstones near CH1, CM1, and WT1 have more clay and shale content than the sandstones near L2. Greater amounts of clay in the sandstones will retand the flushing of residual brines from the sandstones and could result in a shallow base of fresh water near CH1, CM1, and WT1.

Fresh ground water and underlying shallow brines are separated by a mixing zone. The chemical make-up of water in the mixing zone will vary with the composition and percentages of the waters mixed. Discharge boundaries near the Deep Fork are areas of mixing of fresh ground water, shallow brines, and deep circulation brines. Complex mixing makes brine source determinations difficult in these areas. The mixing zone in a recharge area is produced from local water-rock interaction as fresh water moves through in the shallow ground-water environment and dilutes the shallow brines. The mixture should be relatively undisturbed by the circulation of deeper oil brines.

Prue sand oil-field brines are a potential source of salinity in shallow fresh ground water because of oil production operations, surface brine spills, and waterflooding activities. Before 1972 (Bruce Langhus, Oklahoma Corporation Commission, oral commun., 1996) brines generally were held in earth pits until the water evaporated or infiltrated the ground-water sys- 
tem. There is no evidence in the data for regional salinization from the surface but local areas may exist.

L2 was drilled to $560 \mathrm{ft}$ in 14N-06E-34 CBC, near the tribal water-supply wells, to sample a shallow brine or a mixed water that was assumed to be undisturbed by deeper oil brines. A field sample and a duplicate were analyzed from L2-VM/T (appendix 1). Both analyses are presented in the following discussion, where they differ for bromide and deuterium.

\section{Geochemlstry of Saline Ground Water}

Chemistry of the saline ground-water samples varies in composition and concentration on tribal land (appendix 1). CH2-VS, CH3-VS, and CM1-VM are sodium chloride and sodium sulfate water. These moderately saline to very saline (table 4) water samples have TDS of $8,890 \mathrm{mg} /, 3,840 \mathrm{mg} / \mathrm{L}$, and $18,400 \mathrm{mg} / \mathrm{L}$ (appendix 1) respectively. CM2-AD is sodium sulfate water with a slightly saline TDS of $1,340 \mathrm{mg} / \mathrm{L}$. CH1-VM, WT1-VM, and L2-VM/T are briny sodium chloride water (table 4). These samples have TDS of $58,500 \mathrm{mg} /, 78,300 \mathrm{mg} / \mathrm{L}$, and 58,900 $\mathrm{mg} / \mathrm{L}$ respectively. The water from the Prue sand is briny and dominated by sodium chloride. The TDS ranges from 88,200 to $147,000 \mathrm{mg} / \mathrm{L}$.

\section{Brine Detection and Identification Methods}

Ground water can be characterized by several different physical parameters or chemical constituents such as dissolved ion concentrations, isotopic enrichment, TDS, or conductivity. Several methods of brine identification based on relations between constituent concentrations have been discussed by Chebotarev (1955), Rittenhouse (1967), Collins $(1974,1975)$, Whittemore and Pollock (1979), Whittemore (1984, 1988), Morton (1986), Knuth and others (1990), and Richter and Kreitler (1991).

\section{Bromide to Chloride Ratlos and Chloride Concentration}

Dissolved ionic species of chloride and bromide were selected for characterization and comparison of the ground water in the study area. These dissolved species were chosen because they are probably the least reactive with other dissolved species in the ground water and with the solid minerals of the aquifer. The concentrations of these ions in a freshwa- ter/brine mixture is affected only by the concentration of the brine, the concentration of the fresh water, and the relative volumes in the mixture. A plot of the ratio of bromide/chloride concentrations $(\times 10,000)$ and chloride concentration for the water samples is shown in figure 10. At higher chloride concentrations the ratio is relatively constant ratio. A plot of the ratio of iodide/chloride and chloride concentration for the water samples produced similar results.

Morton (1986) reported a brine index threshold value of $400 \mathrm{mg} / \mathrm{L}$ for chloride. The index threshold value is the concentration at which Morton (1986) determined oil-associated brine degradation of fresh water could be identified. Water-quality samples from CH2-VS, CH3-VS, CH1-VM, CM1-VM, WT1-VM, and $\mathrm{L} 2$-VM/T have chloride values greater than 400 $\mathrm{mg} / \mathrm{L}$. For the seven samples from these six sites the bromide/chloride ratio ranged from 42.5 to 52.4. For the $\mathbf{4 5}$ samples having chloride concentrations below $400 \mathrm{mg} / \mathrm{L}$ the bromide/chloride ratio ranged from 8.3 to 200.0 .

A mixing curve envelope was produced on the plot from selected end member samples by the relationship in equation 1.

$$
C_{(\text {mixed wator })} \times V_{1}=\left(C_{1} \times V_{x}\right)+\left(C_{2} \times V_{(1-x)}\right)
$$

where $C_{\text {(mired water) }}, C_{1}$, and $C_{2}$ are the concentrations $(\mathrm{mg} / \mathrm{L})$ of chloride and bromide for the mixed water and the two beginning waters, and $V_{1}, V_{x}$, and $V_{(1-x)}$ are the decimal percentage volume of each water. The bromide/chloride ratio for the mixing curve envelope is calculated from the $\mathbf{C}_{\text {(mirod watur) }}$ values for chloride and bromide. Water samples from the Prue brine and fresh water were chosen as end members. Calculations for the upper mixing curve were made from samples from P1 and the well located at 14N-06E-09 AAA. The lower mixing curve was calculated from samples from $P 2$ and the well located at 13N-06E-08 BCC. The calculated mixing curves for chloride concentrations of greater than $400 \mathrm{mg} / \mathrm{L}$ have a bromide/chloride ratio of approximately 35 to 75 . Ground-water samples from tribal land with higher chloride concentrations plot within the mixing-curve envelope and have ratios between $\mathbf{4 0}$ and $\mathbf{5 0}$.

If a brine is the salinity source for a mixedwater sample that has a chloride concentration greater than $400 \mathrm{mg} / \mathrm{L}$, the bromide/chloride ratio for the two waters would be equal. Dilution of the Prue brines from the waterfloods could produce the bromide and chloride values in the saline water from CH2-VS, 


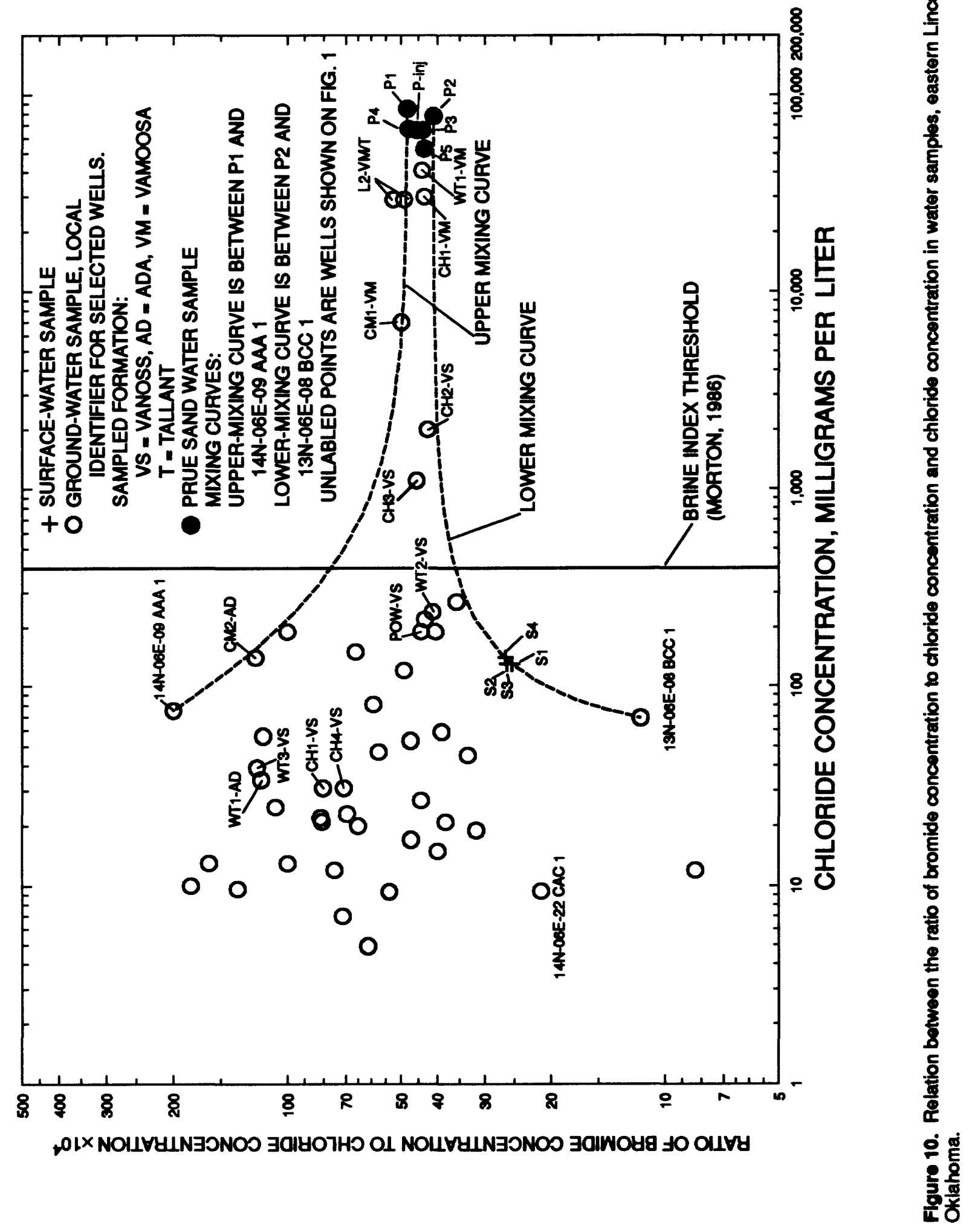


CH3-VS, CH1-VM, CM1-VM, WT1-VM, and L2-VM/T.

Parkhurst and Christenson (1987) presented chemical analyses of water from across Oklahoma. The statewide data indicate other formations, unsampled in the study area, may contain waterthat could produce the mixed-water samples. Therefore, dissolved ionic species cannot determine whether water from the Prue sand in the waterfloods is the only oil brine source for the saline water.

\section{Stable lsotope Evaluation}

Water molecules are composed of the elements of hydrogen and oxygen that have naturally occurring stable isotopes. Stable isotopes are conservative in characterizing the origin of the water molecule. The uses of stable isotopes were discussed in Gat and Gonfiantini (1981) and the application to saline formation water was described in Clayton and others (1966).

Isotopes are atoms of the same element that have different atomic masses, determined by the number of neutrons in the nucleus. Stable isotopes of hydrogen have atomic masses of 1 and 2. The more common or abundant form of hydrogen has a mass number of 1 . The less abundant form has an atomic mass of $\mathbf{2}$ and is named deuterium. Oxygen has three naturally occurring stable isotopes of atomic masses 16,17 , and 18. The more abundant form has a mass of 16 and the less common form has a mass of 18 . The natural abundance of the oxygen isotope of mass 17 is small and was not considered in the analyses.

Atmospheric moisture originates from ocean water that can be considered constant in its isotopic composition (Ferronsky and Polyakov, 1982). As fresh ground water originates as precipitation, an understanding of the distribution of the isotopic species in rain water is important. On a global scale, the natural abundance of deuterium $(\delta \mathrm{D})$ and oxygen-18 $\left(8^{18} \mathrm{O}\right)$ have been related to equation 2 (Craig, 1961).

$$
\delta D(\%)=8 \delta^{18} O(\%)+10
$$

The isotopes are measured as a ratio of $(\delta)$ of the isotope concentration in the sample to the concentration in standard mean ocean water and reported in parts per thousand (\%o) or permil. On a plot of $\delta \mathrm{D}$ versus $\delta^{18} O$, equation 2 plots as a line and is known as the global meteoric water line (Craig, 1961). Several factors affect the distribution of the isotopic species in local rainfall and thus modify equation 2 for local conditions.

The work by Parkhurst and others (1992) on the data from the Central Oklahoma aquifer defined a local meteoric water line for the sandstone aquifers overlying the Vanoss Formation, west of the tribal land. Data from Parkhurst and others (1992) plot along the line in the lower left comer of figure 11, with $8 \mathrm{D}$ values from -30 to -45 and $\delta^{18} \mathrm{O}$ values from -5 to -7 . The equation for the meteoric water line for the Central Oklahoma aquifer is given in equation 3 (Parkhurst and others, 1992).

$$
\delta D(\%)=8 \delta^{18} O\left(\%_{0}\right)+12
$$

The low specific conductance samples from well clusters in the Vanoss Formation and the tribal water-supply well, SF2-VM, are closely associated with the data from the Central Oklahoma aquifer (fig. 11). The precision of the analysis for $\delta \mathrm{D}$ is $1.5(\% \circ)$ and for $\delta^{18} \mathrm{O}$ is $0.1(\%)$ as is shown by the box in figure 11 (Carol Kendall, U.S. Geological Survey, written commun. 1993).

Interaction of ground water with minerals, liquids, and gases in shallow aquifers and deep formations will change the isotopic distribution. The waterrock interaction has a great effect on the isotopic composition of ground water (Kharaka and Thordsen, 1992). If the flow-path conditions ane maintained for a very long time, as in deeper formations or in rocks with poor circulation, ground water will eventually approach an equilibrium with the aquifer and have a distinct distribution of $8 \mathrm{D}$ and $\delta^{18} \mathrm{O}$. Mixing is the only important process controlling the distribution of $\delta \mathrm{D}$ and $\delta^{18} \mathrm{O}$ in ground water for short term reaction times, such as decades.

The samples with high specific conductance from the oil wells, CH1-VM, WT1-VM, and L2-VM/T are not on the local meteoric water line. A linear regression through these samples plots along a line with a slope of 4.0. The precision of the analysis is shown in figure 11 for each of the ground-water samples with $\delta^{18} O$ values greater than -5 .

The isotopic composition of varying mixtures of two waters will plot along a straight line connecting the two end-member waters on a plot of $8 \mathrm{D}$ versus $\delta^{18} \mathrm{O}$ (Arad and others, 1975; Gat, 1981; and Panichi and Gonfiantini, 1981). Several mixing possibilities can be seen in figure 11.

The original, pre-waterflood, isotopic composition of the Prue water is not known. The Prue brine 


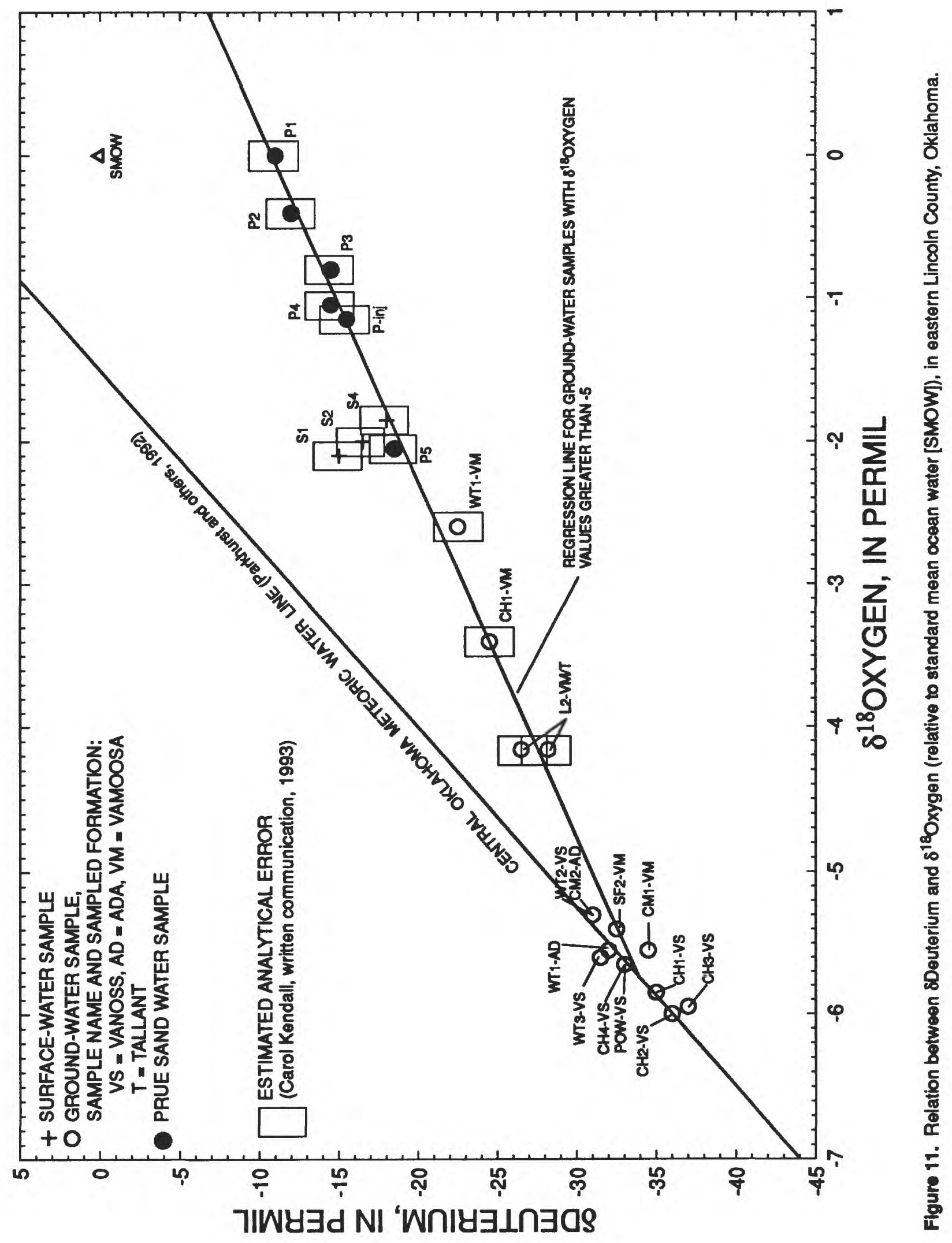


sample P1 has the highest specific conductance, chloride concentration, and TDS. The sample also is farthest from the fresh ground water on the isotope plot (fig. 11). The sample is probably least affected by the waterflooding activity and is probably closest to the original Prue water composition.

Waterflooding of the Prue sand on the tribal land has continued since 1952. Make-up water for the Sac and Fox Prue Sand Unit was reportedly obtained from water-supply wells located in secs. 15 and $16, T$. 14 N., R. 06 E. that were 500 to $600 \mathrm{ft}$ deep (Canard, 1989). Borehole geophysical log correlations indicate the lowest sandstone in L2 (fig. 7) is one of the zones completed in the water-supply wells in secs. 15 and 16. L2-VM/T plots on the regression line with the Prue brines and could have been supplying the makeup water in the waterflood. Fresh ground water also may have been used in the waterfloods and could have produced water compositions along the regression line.

The high-chloride samples CH1-VM, WT1-VM, and L2-VM/T could result from mixing of the Prue brine from the waterflood with any of the fresher ground water on the regression line. The less saline samples from CH2-VS, CH3-VS, and CM1-VM are composed predominately of fresh ground water (fig. 11) and could have a small percentage of brine water. Additional isotope data from other oil producing formations in the area near the tribal land would be needed to determine if the Prue brine has a distinct isotopic composition.

\section{Relation of $\delta^{18}$ Oxygen to Chloride}

Gat (1981) and Craig (1966) discuss the use of plots combining salinity and stable isotopes. A plot of salinity (TDS) in units of $\mathrm{mg} / \mathrm{L}$ and a stable isotope will produce a curved mixing line (Gat, 1981). Craig (1966) proposed a change from units of concentration ( $\mathrm{mg} / \mathrm{L}$ ) to molality (moles/kilogram of water) that would produce a straight mixing line between two end members. Figure 12 is a plot of the chloride molality and $\delta^{18} \mathrm{O}$. Chloride was selected, instead of TDS, because it is conservative and independent of the other species in the ground-water solution and of the lithologies of the aquifers. The concentration of chloride in a freshwater/brine mixture is affected only by the freshwater chloride concentration, the brine chloride concentration, and the relative volumes in the mixture. The molality values were calculated by WATEQF of the NETPATH input program (Plummer and others, 1991).

A linear regression through samples P1, P2, P3, P4, P5, and P-inj plots along a line with a slope of 5.08 (fig. 12). The straight line mixing suggested by Craig (1966) is along the regression line. The briny water (table 4) from CH1-VM, and WT1-VM (appendix 1) are on the mixing line with the waterfiood samples and could have resulted from mixing of the Prue brine with fresh ground water.

The briny water from L2-VM/T and the very saline water from CM1-VM (fig. 3) are slightly more depleted in the $\delta^{18} \mathrm{O}$ isotope and are not on the mixing line of the first group. A second possible mixing line along a linear regression through moderately saline CH2-VS and slightly saline CH3-VS, CM1-VM, and L2-VM/T plots along a line with a slope of 6.04 . CM1-VM and L2-VM/T could be mixtures of the Vanoss Formation fresh ground water and a Prue brine near P1 composition or mixtures of the Vanoss Formation fresh ground water and a residual brine of unknown composition. Residual brines may be found in shallow sandstones and shales that have low hydraulic conductivity and recharge such as CM1 (fig. 5) or in deeper sandstones that have not been diluted by freshwater recharge such as L2 (fig. 7). If the briny water from L2-VM/T was used in the initial waterflooding in the Prue sand, the relationship is not as apparent in figure 12 as it is suggested in figure $\mathbf{1 1}$.

Water-quality data indicate there may be more than one source for the salinity in the very saline and briny samples near the tribal land (fig. 12). The data suggest both sources have mixed with the fresh ground water from the Vanoss Formation.

\section{SUMMARY AND CONCLUSIONS}

Water-quality sampling and borehole geophysical data indicate the potential for fresh ground water on tribal land generally is greatest in the Vanoss Formation, in the SE1/4 sec. 21, T. 14 N., R. 06 E. and in the NE1/4 sec. 22, T. 14 N., R. 06 E. These locations avoid the flood-prone areas and borehole geophysical resistivity logs indicate the altitude of the base of fresh ground water is below $650 \mathrm{ft}$. Borehole geophysical logs indicate the altitude of the base of fresh ground water is generally near the surface under the W1/2 sec. 22, T. 14 N., R. 06 E., the SE1/4 section 22, SE1/4 


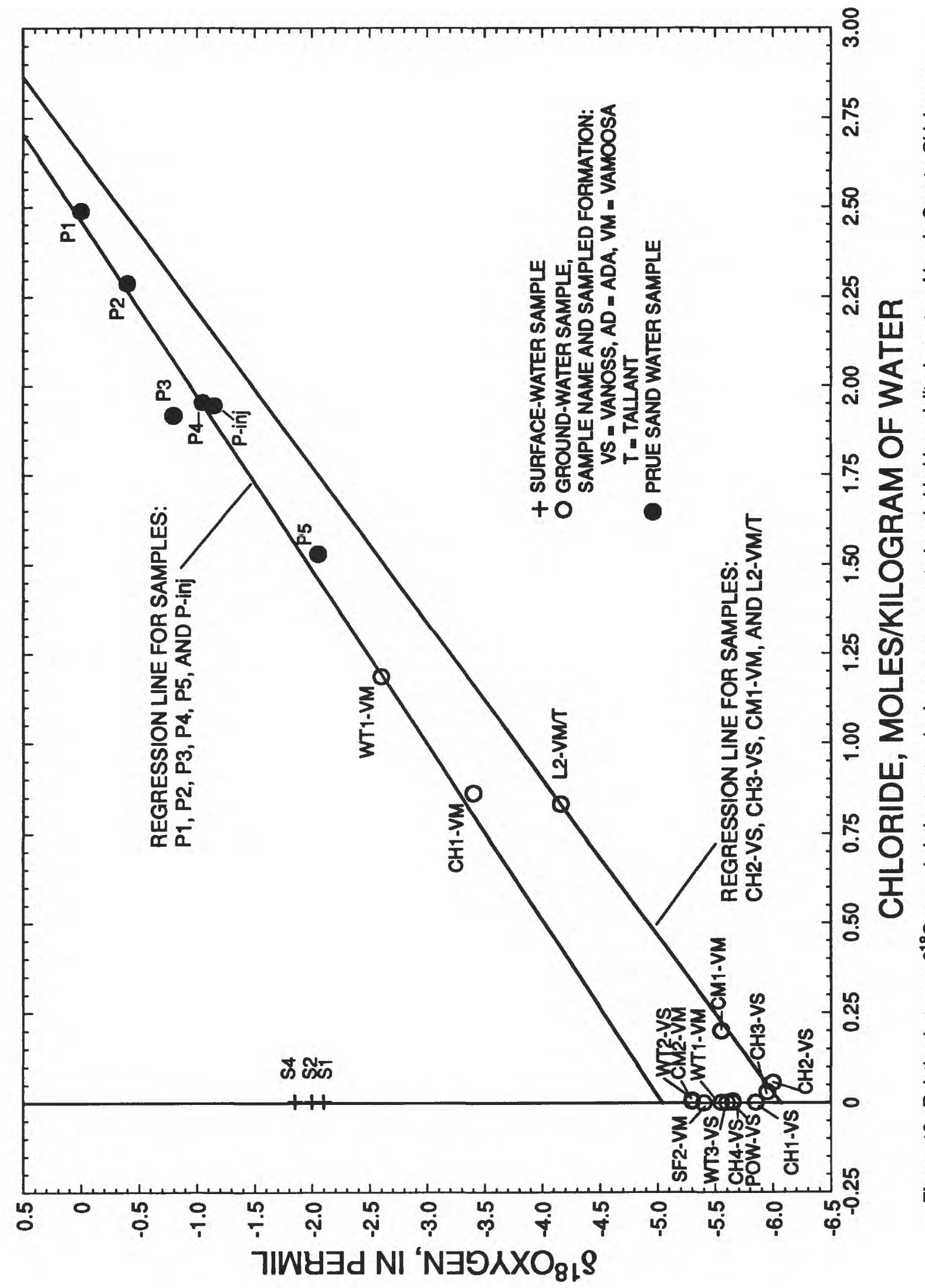

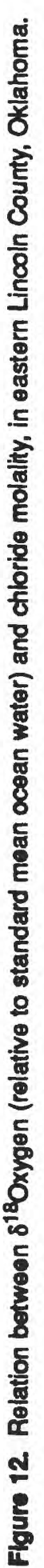


SE1/4 NE1/4 section 21, and NE1/4 NW1/4 NW1/4 section 27.

Conditions are more favorable for placement of fresh ground-water wells near SF1 and SF2 in section 34 , where the tribe has leased water rights, than on tribal land in secs. 15, 16, 21, and 22, T. 14 N., R. 06 E. Sandstones overlain by or enclosed in thick clay and shale sequences are likely to be somewhat isolated from the flow system and retain some of the residual brine. Borehole geophysical logs suggest that sandstones near CH1, CM1, and WT1 have more clay and shale content than the sandstones near L2. Greater amounts of clay in the sandstones will retard the flushing of residual brines from the sandstones and could result in a shallow base of fresh water near CH1, CM1, and WT1. For these reasons and because circulation of fresh ground water is limited by discharge to the Deep Fork, general water quality under tribal land would probably be poorer than in the area where the tribe has leased water rights near SF1 and SF2.

Ground water from the Ada and Vamoosa Formations, from the area where the altitude of the base of fresh ground water is near the surface, have high sodium chloride and high sodium sulfate concentrations on tribal land. Water-quality samples CH2-VS, CH3-VS, CM2-AD, CH1-VM, CM1-VM, WT1-VM, and L2-VM/T have chloride or sulfate concentrations greater than $250 \mathrm{mg} / \mathrm{L}$. Two possible sources for chloride and sulfate in water-quality samples are shallow brines and deep brines from oil production at 3,000 ft. Probable sources of shallow brine in the study area are: 1) solution of minerals as fresh water moves through the aquifer and 2) residual brine deposited with the sediment. There are no salt or gypsum beds in the Vanoss, Ada, or Vamoosa Formations, but there may be nodules and finely disseminated minerals present in the formations. Residual brine could remain in sandstones and shales that have low hydraulic conductivity and have not been diluted by freshwater recharge.

If a brine is the salinity source for a mixedwater sample the bromide/chloride ratio for the two waters will be equal. Dilution of the Prue brines from the waterfloods could produce the bromide and chloride values in the saline water from CH2-VS, CH3VS, CH1-VM, CM1-VM, WT1-VM, and L2-VM/T. The statewide data indicate other formations, unsampled in the study area, may contain water that could produce the mixed-water samples.
The isotopic composition of varying mixtures of two waters will plot along a straight line connecting the two end-member waters on a plot of $8 D$ versus $\delta^{18} \mathrm{O}$. L2-VM/T plots on the regression line with the Prue brines and could have been supplying the makeup water in the waterfood. Fresh ground water also may have been used in the waterfloods and could have produced water compositions along the regression line. The high-chloride samples CH1-VM, WT1-VM, and L2-VM/T could result from mixing of the Prue brine from the waterflood with any of the fresher ground water on the regression line. Additional isotope data from other oil producing formations in the area near the tribal land would be needed to determine if the Prue brine has a distinct isotopic composition.

A mixture of two waters plot along a straight line on a plot of chloride molality and a stable isotope $\left(\delta^{18} \mathrm{O}\right)$. A linear regression through samples $\mathrm{P} 1, \mathrm{P} 2$, P3, P4, P5, and P-inj plots along a line with a slope of 5.08. The briny water from CH1-VM, and WT1-VM are on the mixing line with the waterflood samples. The briny water from L2-VM/T and the very saline water from CM1-VM are slightly more depleted in the $\delta^{18} \mathrm{O}$ isotope and are not on the mixing line of the first group. A second possible mixing line along a linear regression through moderately saline $\mathrm{CH} 2-\mathrm{VS}$ and slightly saline CH3-VS, CM1-VM, and L2-VM/T plots along a line with a slope of 6.04. If the briny water from L2-VM/T was used in the initial waterflooding in the Prue sand, the relationship is not as apparent on a plot of chloride molality and $\delta^{18} \mathrm{O}$ isotope. Water-quality data indicate there may be more than one source for the salinity in the very saline and briny samples near the tribal land. Data suggest both sources have mixed with the fresh ground water from the Vanoss Formation.

\section{SELECTED REFERENCES}

Arad, A., Kafri, U., and Fleischer, E., 1975, The Na'aman springs, Northern Israel: Salinisation mechanism of an irregular freshwater-seawater interface: Journal of Hydrology, v. 25, p. 81.

Bingham, R.H., and Bergman, D.L., 1980, Reconnaissance of the water resources of the Enid quadrangle, northcentral Oklahoma: Oklahoma Goological Survey Hydrologic Atlas 7, 4 sheets, scale 1:250,000.

Bingham, R.H., and Moore, R.L., 1975, Reconnaissance of the water resources of the Oklahoma City quadrangle, 
central Oklahoma: Oklahoma Geological Survey

Hydrologic Atlas 4, 4 sheets, scale 1:250,000.

Canard, Curtis, 1989, Final Report, Subcontract to BIA Contract BOOC14208716, 17 p.

Chebotarev, I.I., 1955, Metamorphism of natural waters in the crust of weathering, pts. 1-3: Geochimica et Cosmochimica Acta, v. 8, p. 22-48, 137-170, 198-212.

Clayton, R.N., Friedman, I., Graf, D.L., Mayeda, T., Meents, W.F., and Shimp, N.F., 1966, The origin of saline formation waters: 1. Isotopic Composition: Journal of Geophysical Research, v. 71, p. 3869.

Cole, J.A., 1958, Subsurface geology of east central Lincoln County, Oklahoma: Oklahoma City Geological Society Shale Shaker Digest, v. II, p. 79-96.

Collins, A.G., 1974, Saline groundwaters produced with oil and gas: U.S. Bureau of Mines Project Report 16060 EOO for the U.S. Environmental Protection Agency, 68 p.

1975, Geochemistry of oilfield waters: Amsterdam, Elsevier, $496 \mathrm{p}$.

Craig, H., 1961, Isotopic variations in meteoric waters: Science, v. 133, p. $1702-1703$.

1966, Isotopic composition and origin of the Red Sea and Salton Sea geothermal brines: Science, v. 154, p. 1544.

D'Lugosz, J.J., MoClafin, R.G., and Marcher, M.V., 1986, Geohydrology of the Vamoosa-Ada aquifer, cast-central Oklahoma: Oklahoma Geological Survey Circular 87,41 p.

Ferronsky, V.I., and Polyakov, V.A., 1982, Environmental Isotopes in the Hydrosphere: New Yort, Wiley, 466 p.

Fishman, M.J., and Friedman, L.C., 1989, Methods for determination of inorganic substances in water and fluvial sediments: U.S. Geological Survey Techniques of Water-Resources Investigations, book 5, chap. A1, 545 p.

Freeze, R.A., and Cherry, J.A., 1979, Groundwater: Englewood Cliffs, N. J., Prentice-Hall, 604 p.

Gat, J.R., 1981, Groundwater, in Gat, J.R.; and Gonfiantini, R., eds., 1981, Stable isotope hydrology, deuterium and oxygen-18 in the water cycle: Vienna, Technical Reports Series No. 210, Intemational Atomic Energy Agency, p. 223-238.

Gat, J.R., and Gonfiantini, R., eds., 1981, Stable isotope hydrology, deuterium and oxygen-18 in the water cycle: Vienna, Technical Reports Series No. 210, International Atomic Energy Agency, 339 p.

Hart, D.L., Jr., 1974, Reconnaissance of the water resources of the Ardmore and Sherman quadrangles, southern Oklahoma: Oklahoma Geological Survey Hydrologic Atlas 3, 4 sheets, scale 1:250,000.

Heath, R.C., 1991, Basic ground-water hydrology [6th ed.]: U.S. Geological Survey Water-Supply Paper 2220584 p.
Keys, W.S., 1988, Borehole geophysics applied to groundwater investigations: U.S. Geological Survey OpenFile Report 87-539, 305 p.

Keys, W.S., and MacCary, L.M., 1973, Location and characteristics of the interface between brine and fresh water from geophysical logs of boreholes in the Upper Brazos River basin, Texas: U.S. Geological Survey Professional Peper 809-B, p. B1-B23.

Kharaka, Y.K., and Thordsen, JJ., 1992, Stable isotope geochemistry and crigin of waters in sedimentary basins, in Claver, Norbert, and Chaudhuri, Sambhu, eds., 1992, Isolopic signatures and sedimentary records: New York, Springer-Verlog, 529 p.

Knuth, Martin, Jackson, J.L., and Whittemore, D.O., 1990, An integrated approach to identifying the salinity source contaminating a ground-water supply: Groundwater, v. 28, no. 2 , p. 207-214.

Laine, L.L., Schoff, S.L., and Dover, T.B., 1951, Public water supplies in Oklahoma: U.S. Geological Survey Open-File Repart 51-201, p. 80-81.

Levorsen, A.I., 1929, Greater Seminole district, Seminole and Pottawatomic Counties, Oklahoma, in Structure of typical American oil fields, v. 2: American Association of Petroleum Geologists, p. 315-361.

Masters, K.E., 1958, Geology of the Prague area, Lincoln and Pottawatomic Counties, Otlahoma: Otlahoma City Geological Society Shale Shaker Digest, v. II, p. 227-234.

Miser, H.D., 1954, Geologic map of Oklahoma: Oklahoma Geological Survey and U.S. Geological Survey, scale 1:500,000.

Morton, R.B., 1986, Effects of brine on the chemical quality of water in perts of Creek, Lincoln, Okfuskee, Payne, Pottawatomie, and Seminole Counties, Oklahoma: Otlahoma Geological Survey Cincular 89, 38 p.

Oakes, M.C., 1959, Geology of Creek County: Oklahoma Geological Survey Bulletin 81, 134 p.

Oakes, M.C., and Branson, C.C., 1956, Stratigraphy along the Tumer Turnpike, in Geology of the Tumer Tumpike: Oklahoma Geological Survey, Guide Book IV, p. 9-19.

Panichi, C., and Gonfiantini, R., 1981, Geothermal waters, in Gat, J.R., and Gonfiantini, R., eds., 1981, Stable isotope hydrology, deuterium and oxygen-18 in the water cycle: Vienna, Technical Reports Series No. 210, International Atomic Energy Agency, p. 241-268.

Parkhurst, D.L., Christenson, Scott, and Breit, G.N., 1992, Ground-water-quality assessment of the central Oldahoma aquifer, Oklahoma: Geochemical and geohydrologic investigations: U.S. Geological Survey Open-File Report 92-642, 222 p.

Parkhurst, R.S., and Christenson, S.C., 1987, Selected chemical analyses of water from formations of Mesozoic and 
Paleozoic age in parts of Oklahoma, Northern Texas, and Union County, New Mexico: U.S. Geological Survey Water-Resources Investigations Report

86-4355, 222 p.

Plummer, L.N., Prestemon, E.C., and Parkhurst, D.L., 1991, An interactive code (NETPATH) for modeling net geochemical reactions along a flow path: U.S. Geological Survey Water-Resources Investigations Report 914078, $227 \mathrm{p}$.

Ries, E.R., 1954, Geology and mineral resources of Otfuskee County, Oklahoma: Oklahoma Geological Survey Bulletin 71, 120 p.

Richter, B.C., and Kreitler, C.W., 1991, Identification of sources of ground-water salinization using geochemical techniques: U.S. Environmental Protection Agency, Office of Research and Development, Robert S. Kerr Environmental Research Laboratory, Report EPA $600 / 2-91 / 064,259$ p.

Rittenhouse, Gordon, 1967, Bromine in oil-field waters and its use in determining possibilities of origin of these waters: American Association of Petroleum Geologists Bulletin, v. 51, p. 2430-2440.

Robinove, CJ., Langford, R.H., and Brookhart, J.W., 1958. Saline-water resources of North Dakota: U.S. Geological Survey Water-Supply Paper 1428, 72 p.

Smith, O.M., ed., 1942, The chemical analyses of the waters of Otlahoma: Otlahoma Agricultural and Mechanical College, Engineering Experiment Station, Publication No. 52, St. Louis, John S. Smith, p. 168-169.
Thatcher, L.L., Janzer, V.J., and Edwards, K.W., 1977, Methods for determination of radioactive substances in water and fluvial sediments: U.S. Geological Survey Techniques of Water-Resources Investigations, book 5 , chap. A5, 95 p.

Wells, F.C., Gibbons, W.J., and Dorsey, M.E., 1990, Guidelines for collection and field analysis of water-quality samples from streams in Texas: U.S. Geological Survey Open-File Report 90-127, $79 \mathrm{p}$.

Whittemore, D.O., 1984, Geochemical identification of salinity sources, in French, R.H., Salinity in watercourses and reservoirs: Proceedings of the 1983 International Symposium of State-of-the-Art Control of Salinity, Salt Lake City, Utah, p. 505-514.

-1988, Bromide as a tracer in ground-water studies: Geochemistry and analytical determination: National Water Well Association, Proceedings, Ground Water Geochemistry Conference, Denver, Colorado, February 16-18, 1988, p. 339-359.

Whittemore, D.O., and Pollock, L.M., 1979, Determination of salinity sources in water resource of Kansas by minor alkali metal and halide chemistry: Kansas Water Resources Research Institute Contribution, no. 208, 28 p.

U.S. Environmental Protection Agency, 1989, National primary and secondary drinking water regulations; (sections 141.50, 141.51, 141.61, and 141.62 of part 141 and 143.3 of pert 143): U.S. Code of Federal Register, v. 54, no. 97, May 22, 1989, p. 22, 06-22, 160. 


\section{APPENDIXES}




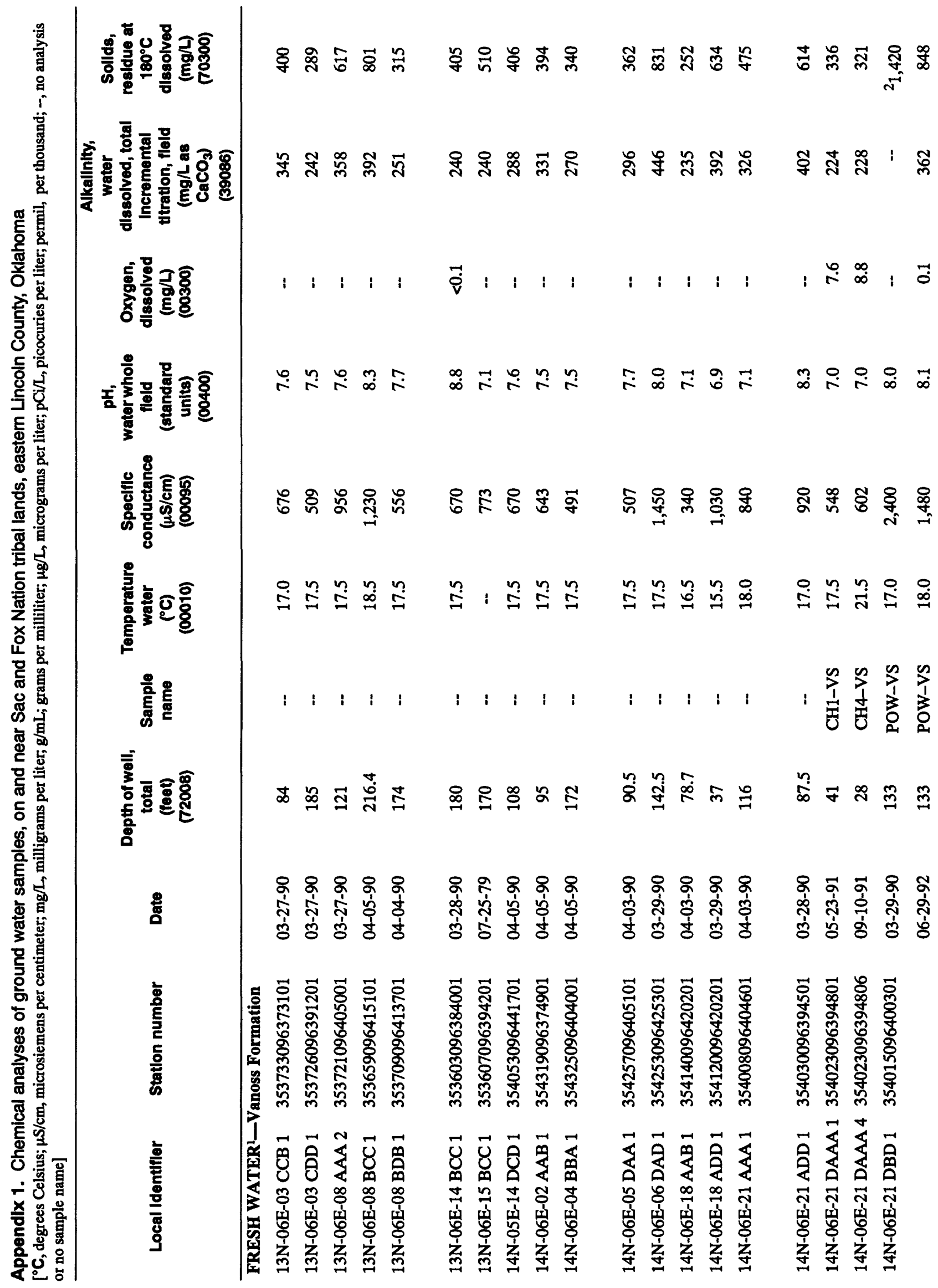




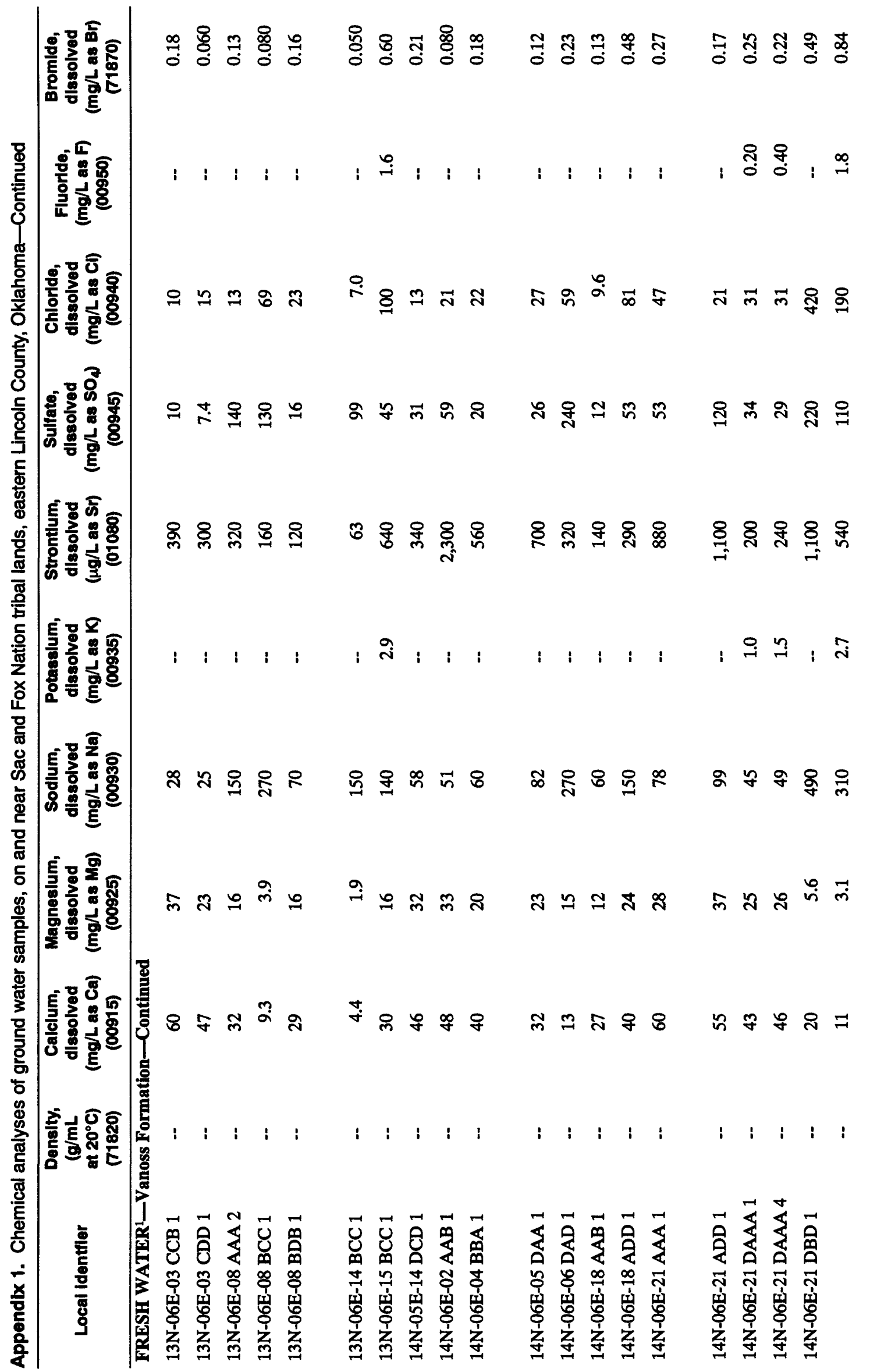




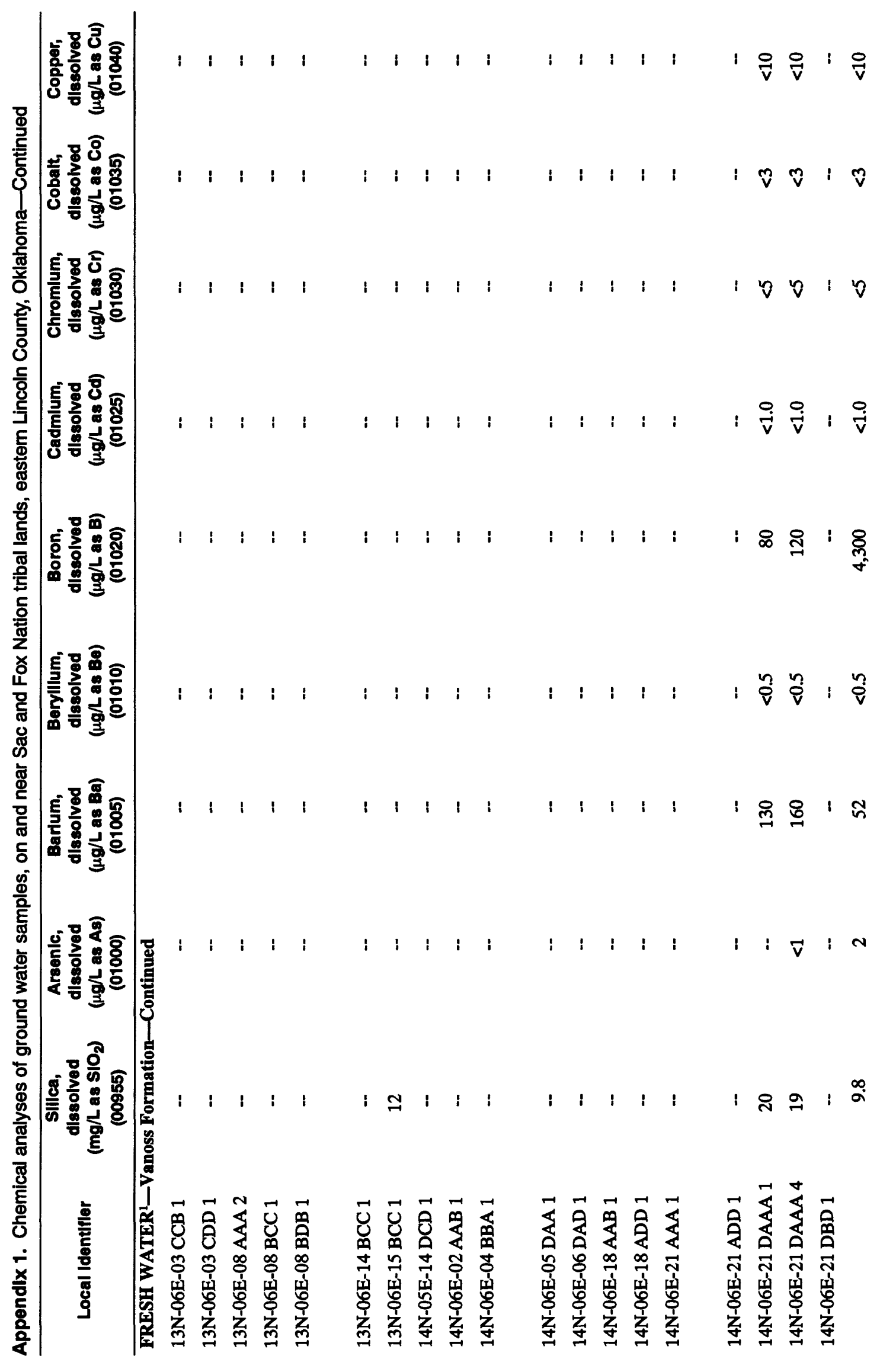




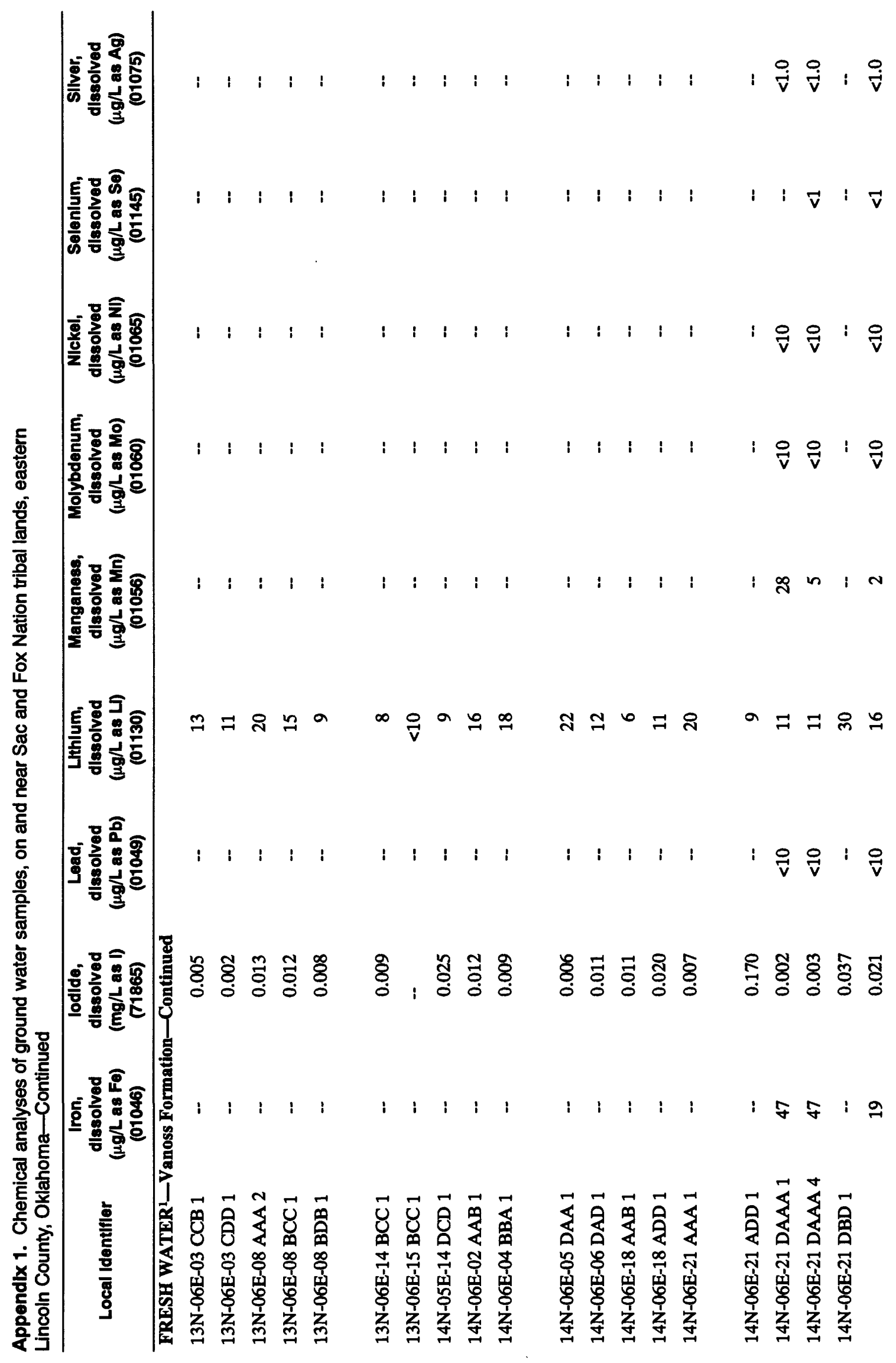




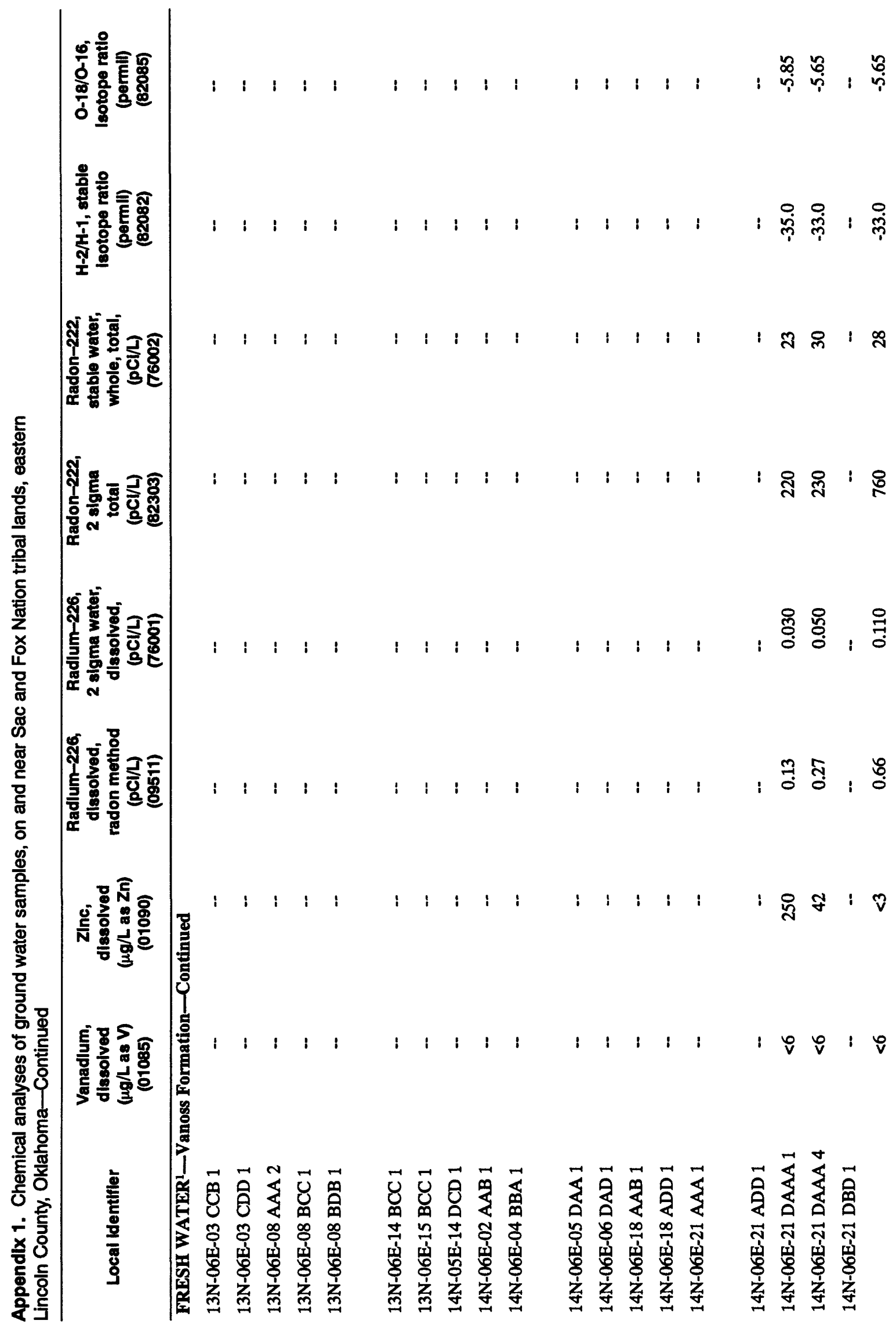




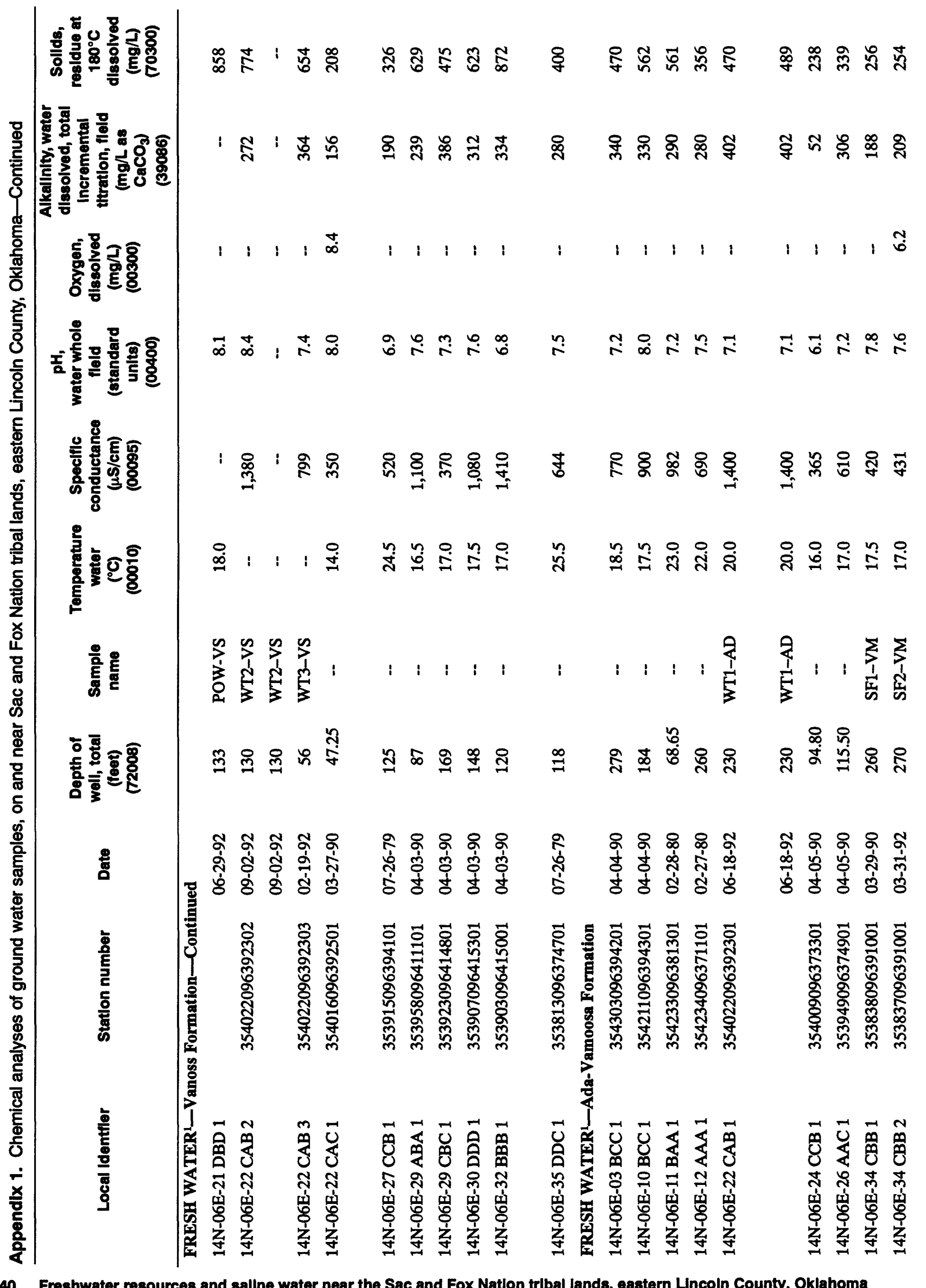




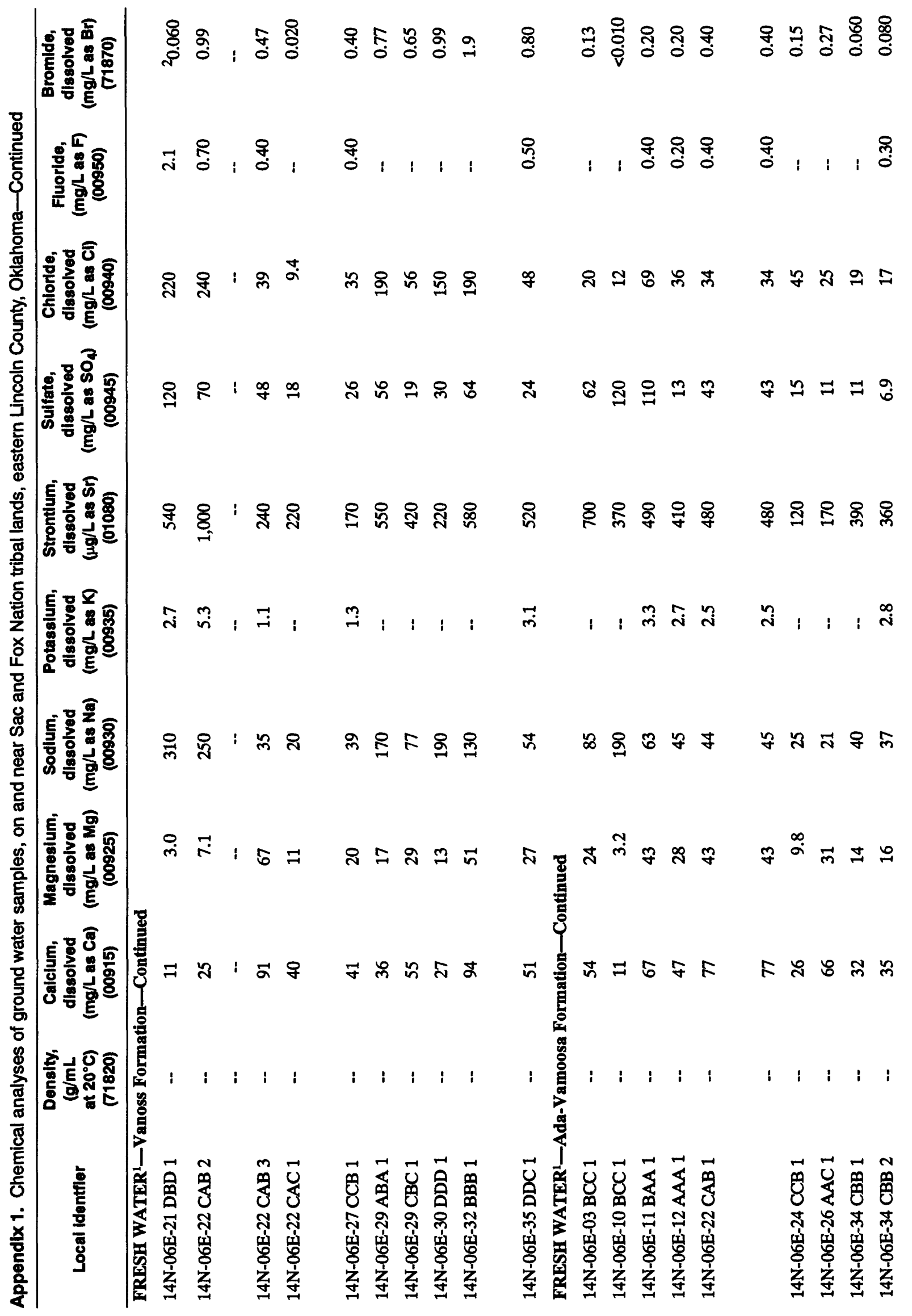




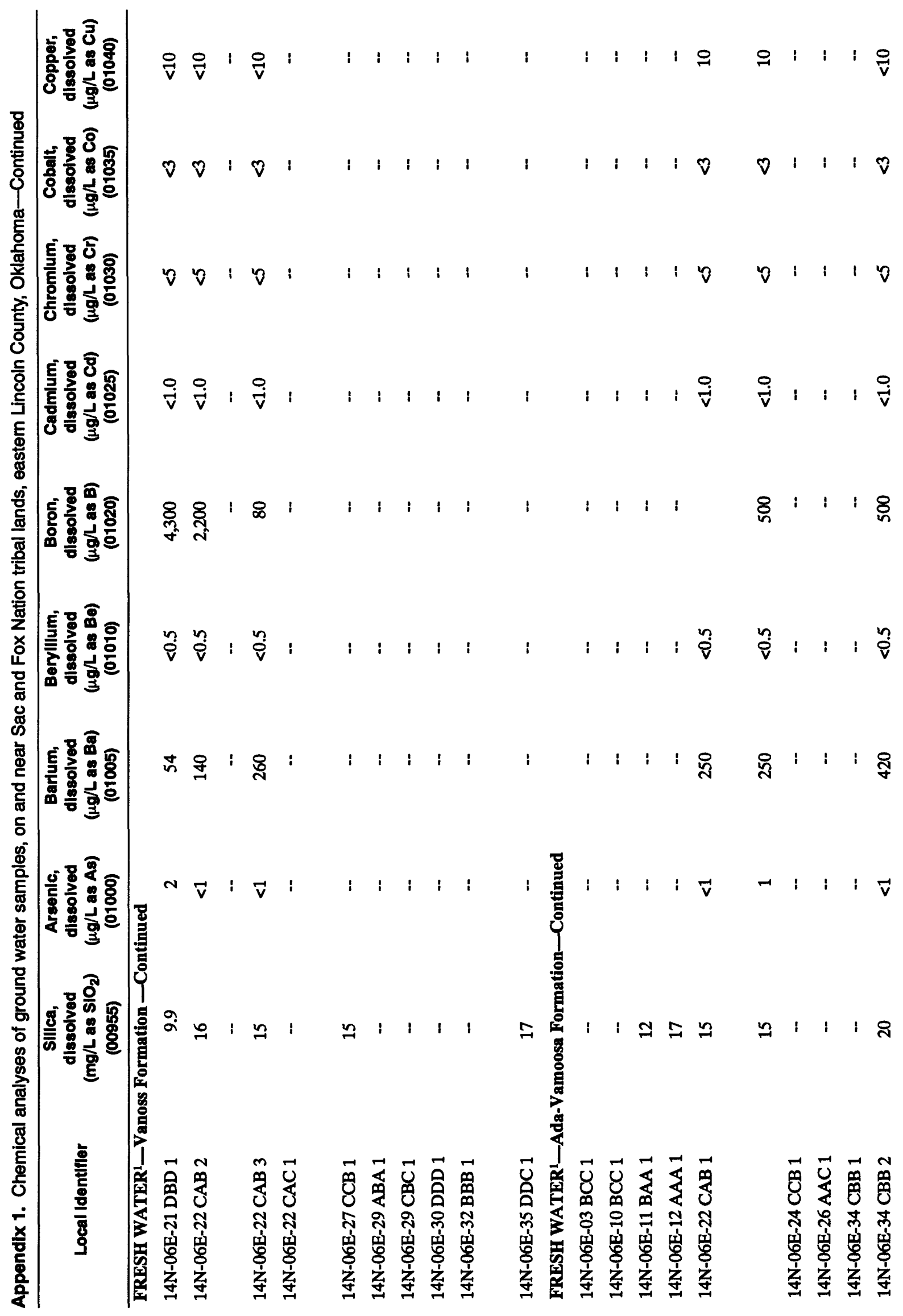

42 Freshwater resources and sallne water near the Sac and Fox Natlon tribal lands, eastern Lincoln County, Oklahoma 


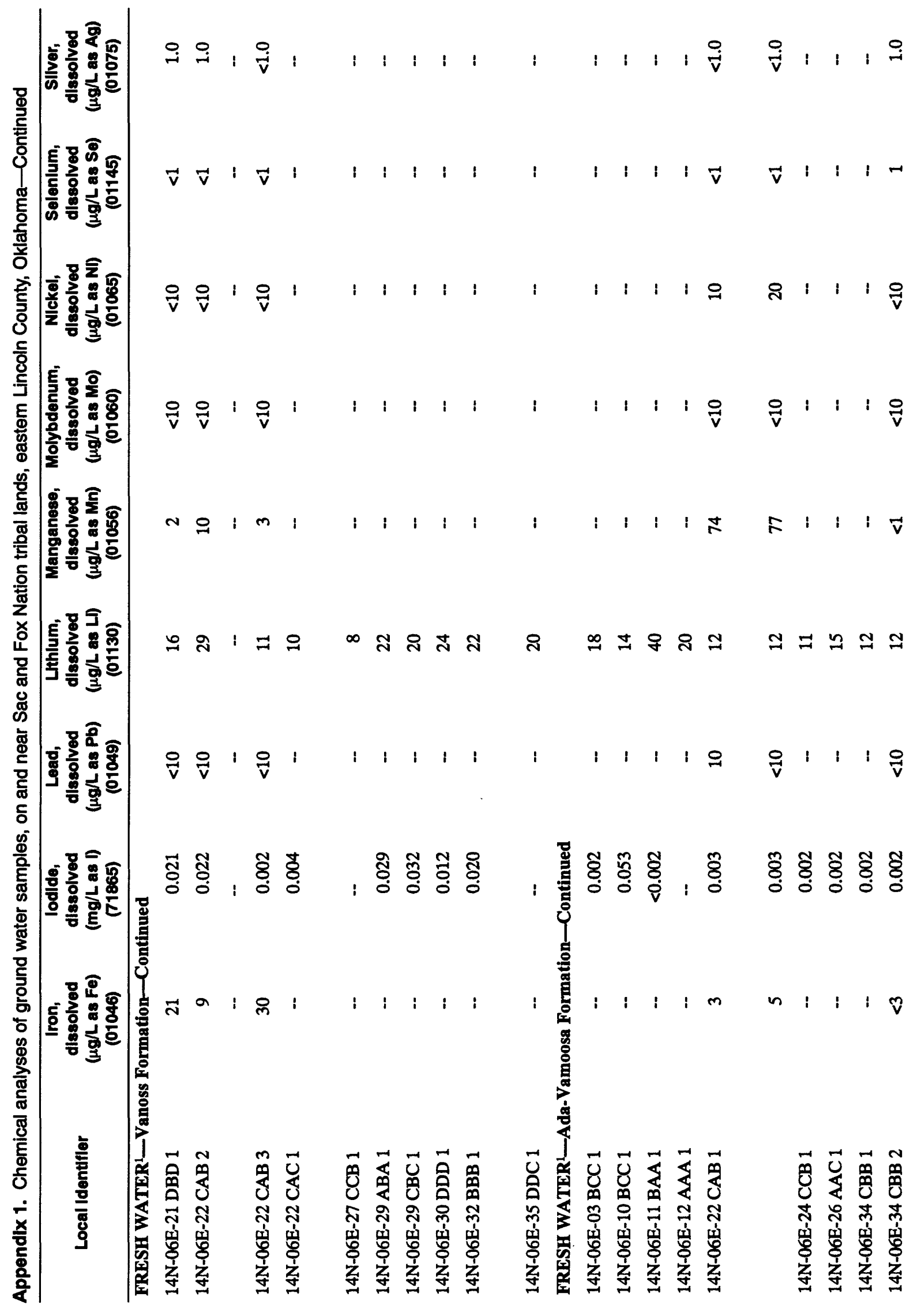




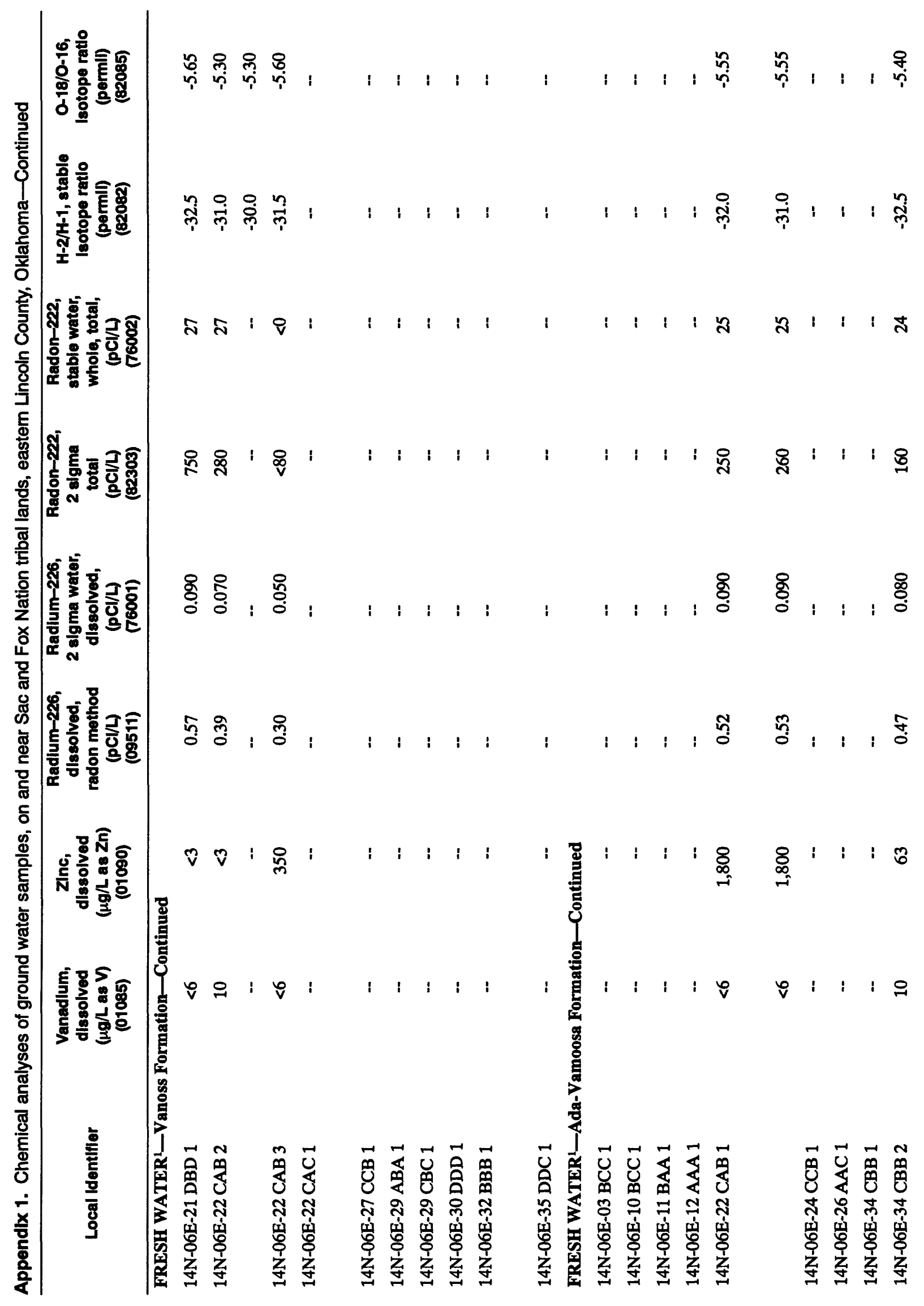

44 Freshwater resources and sallne water near the Sac and Fox Nation tribal lands, eastern Lincoln County, Okiahoma 


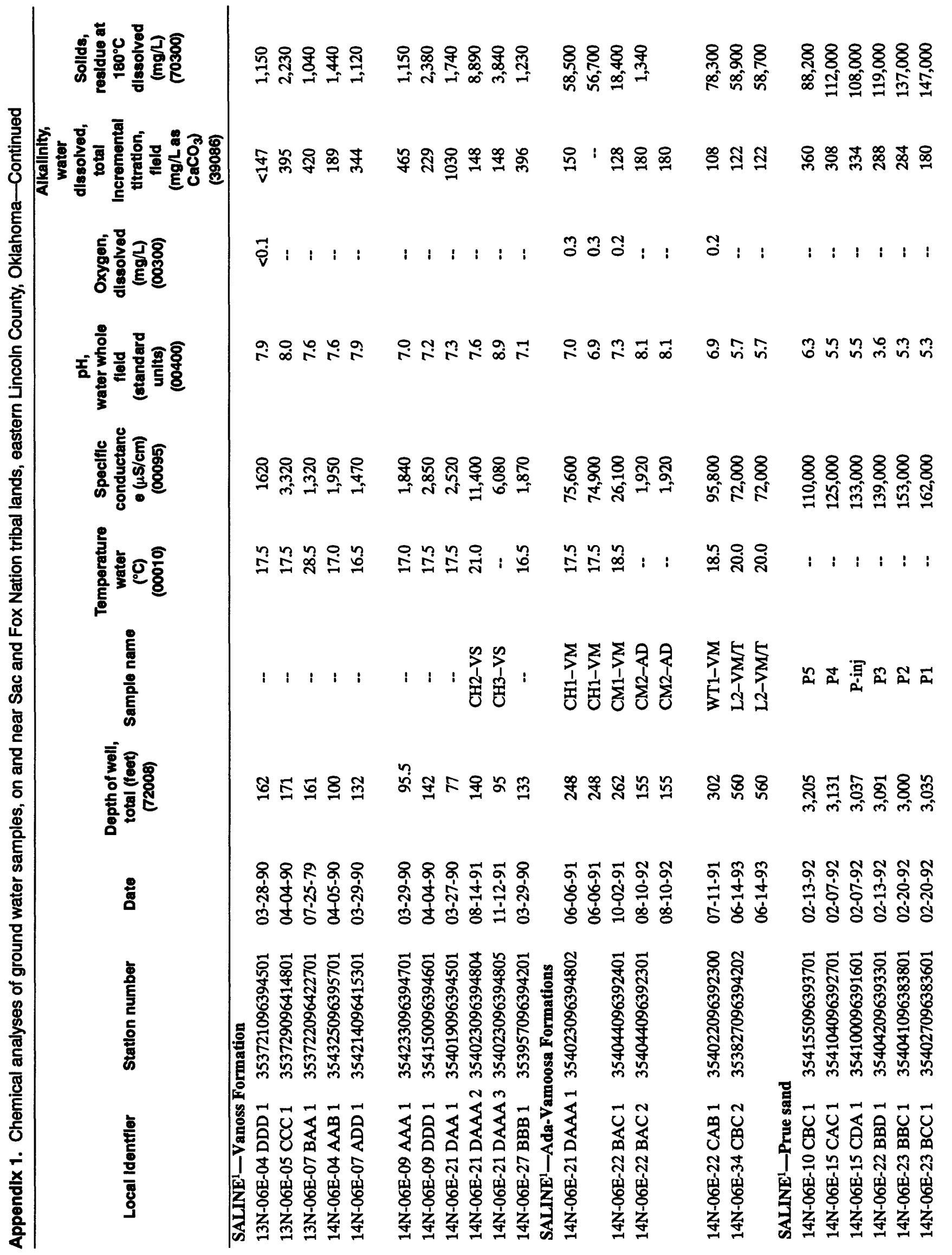




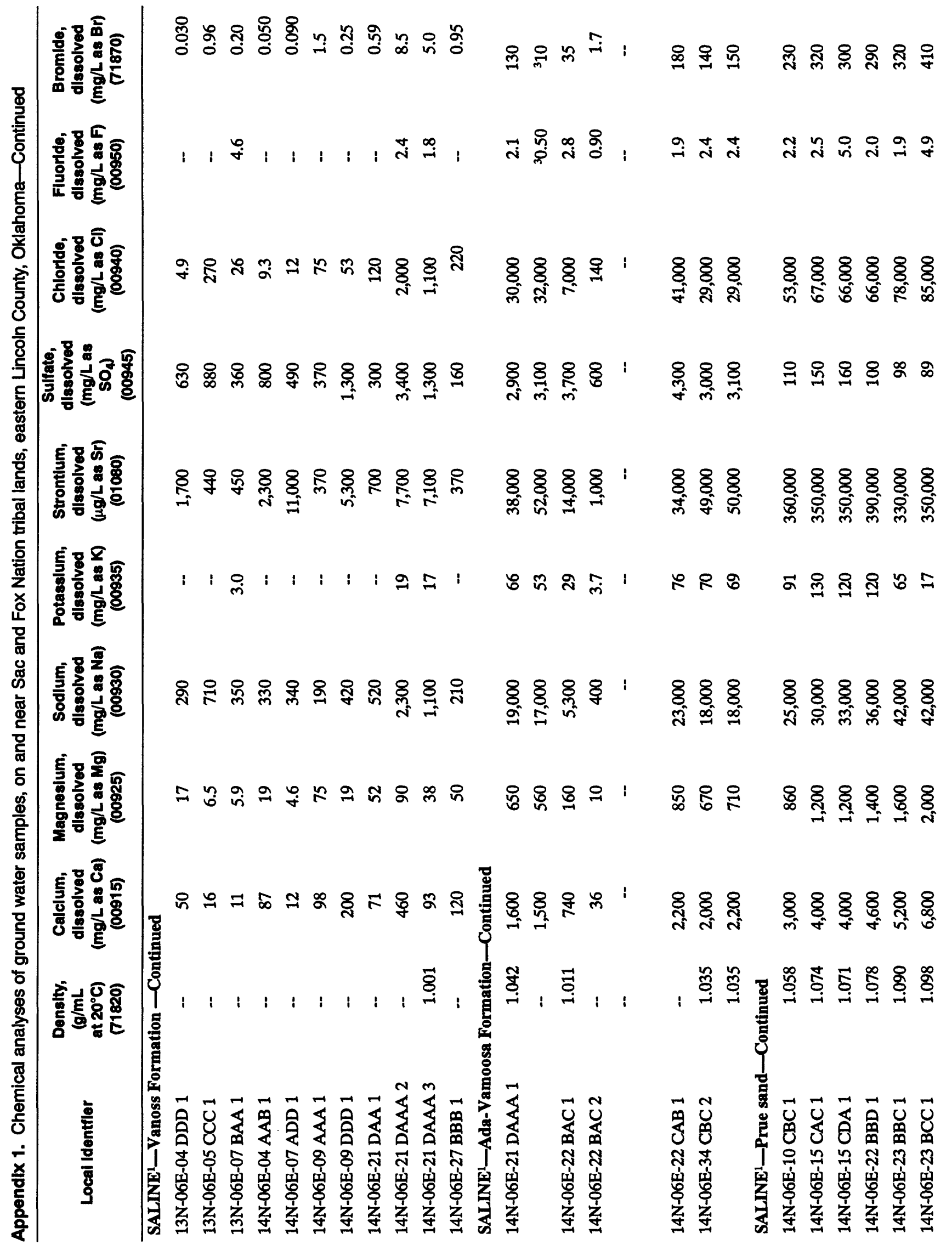




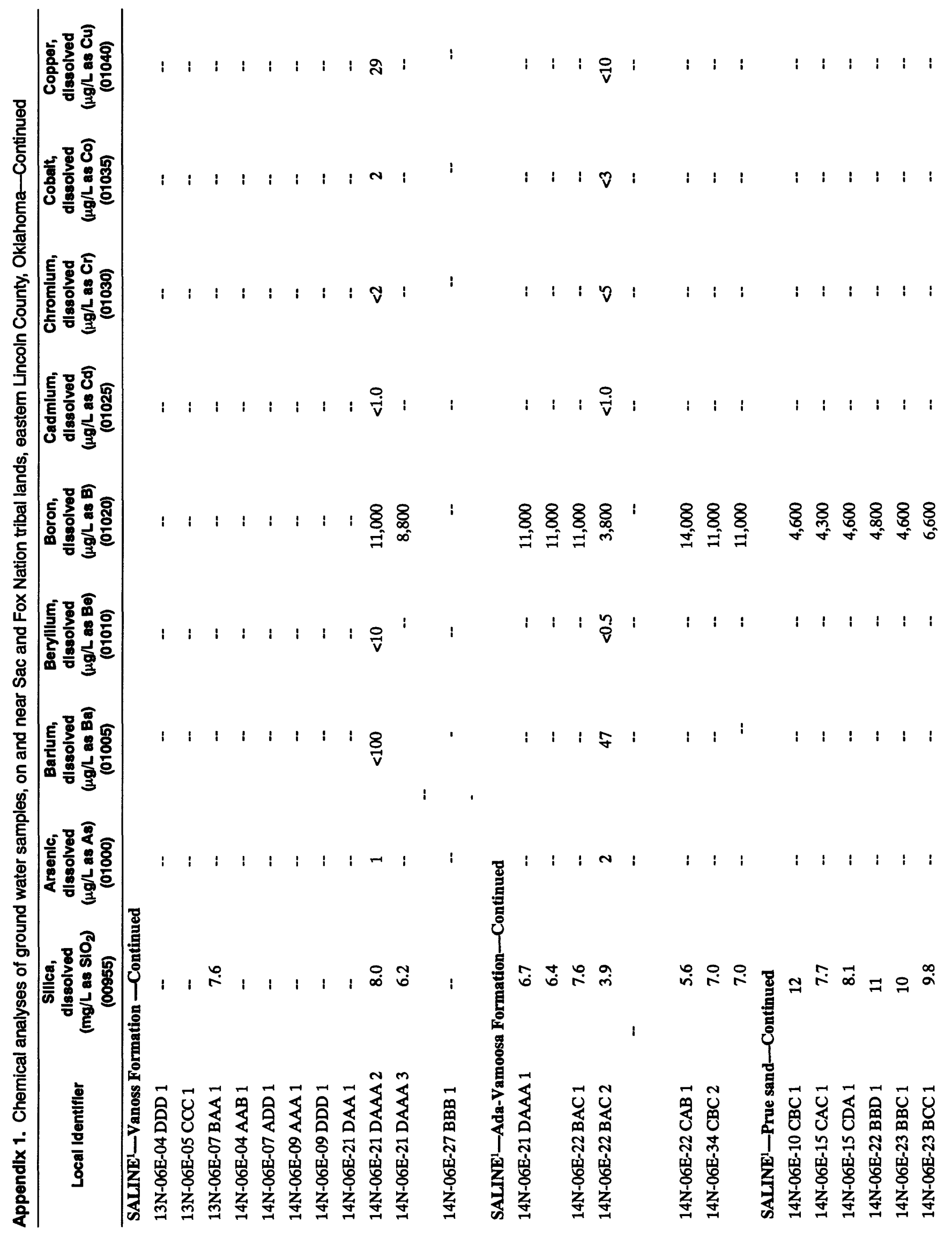




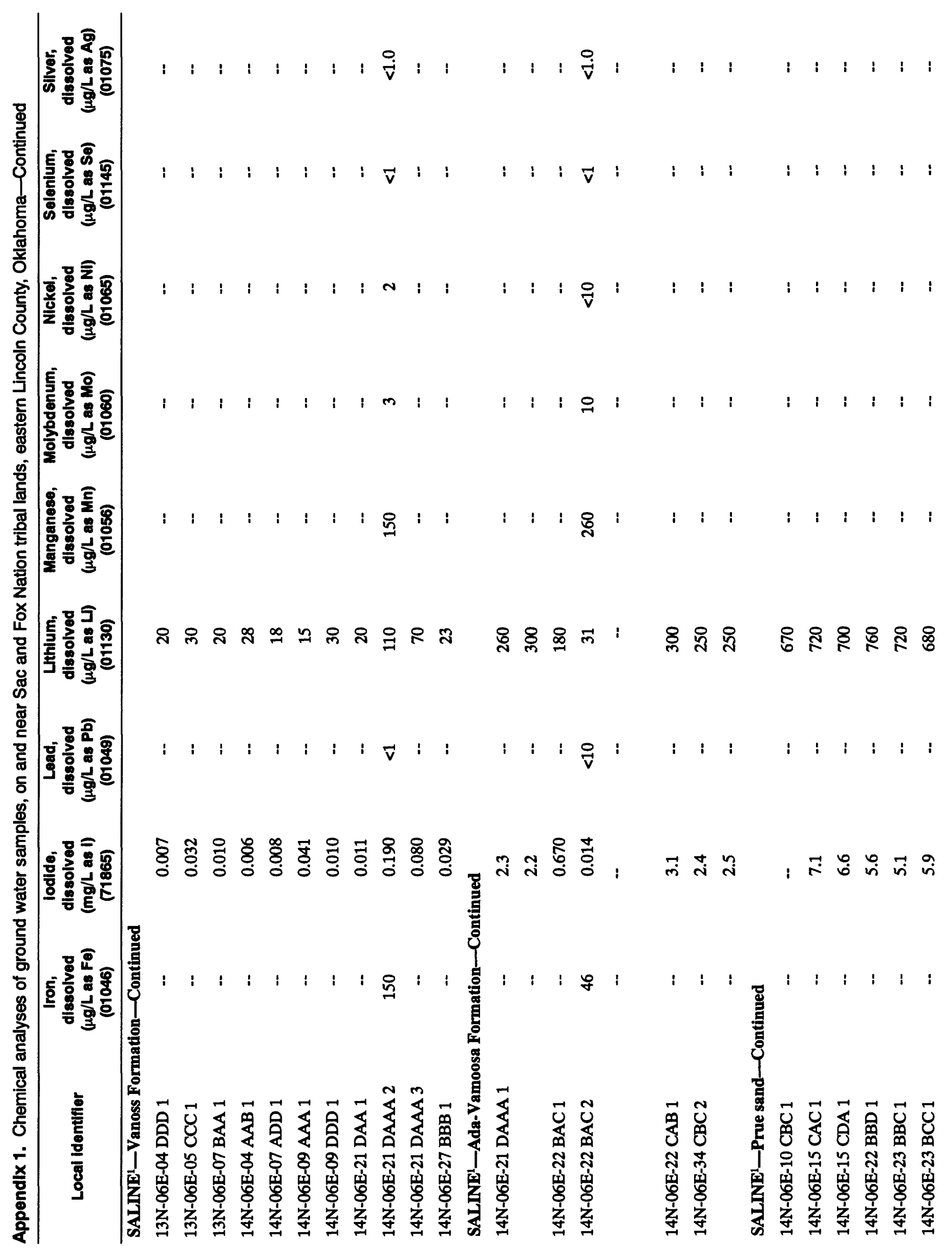




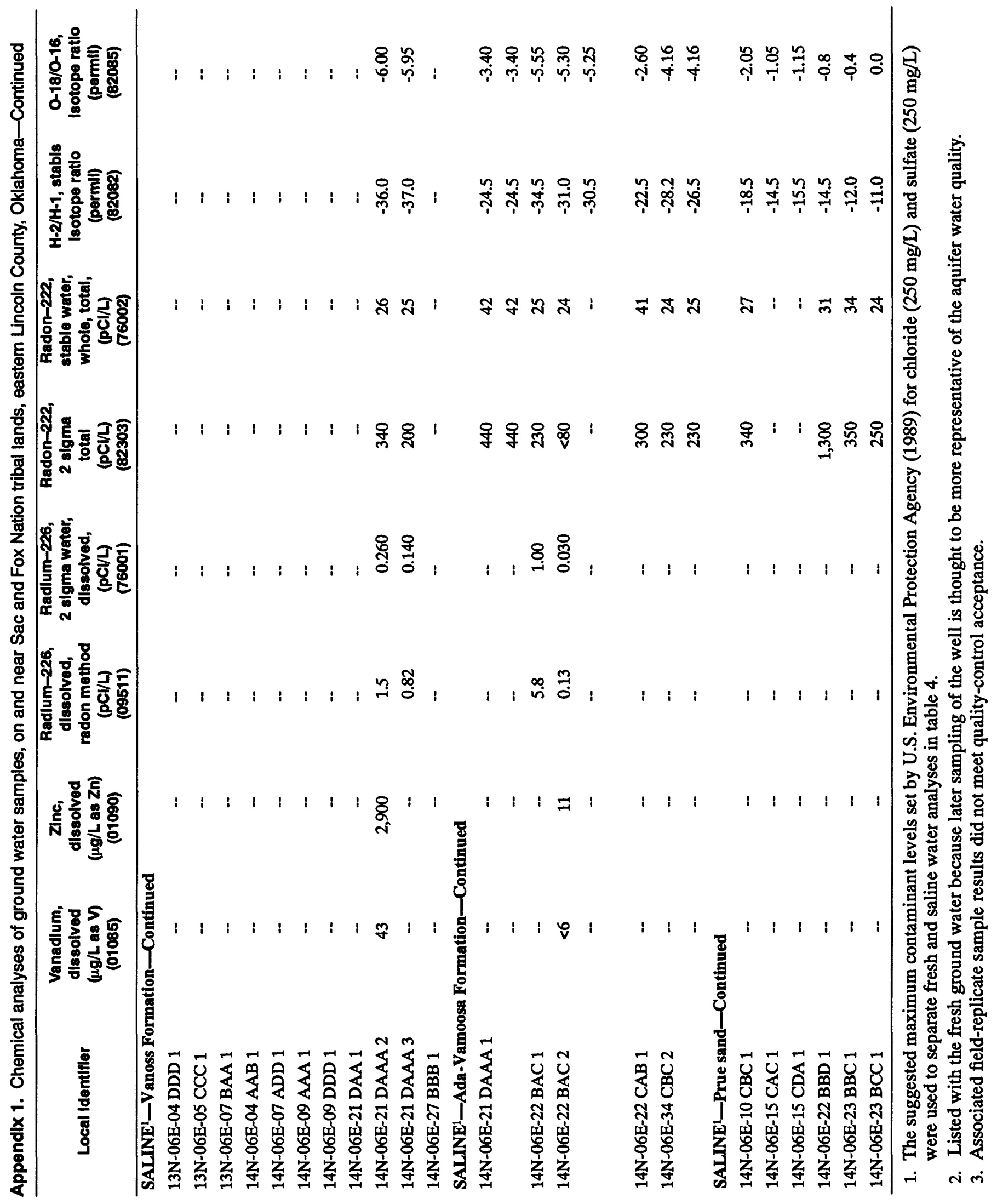




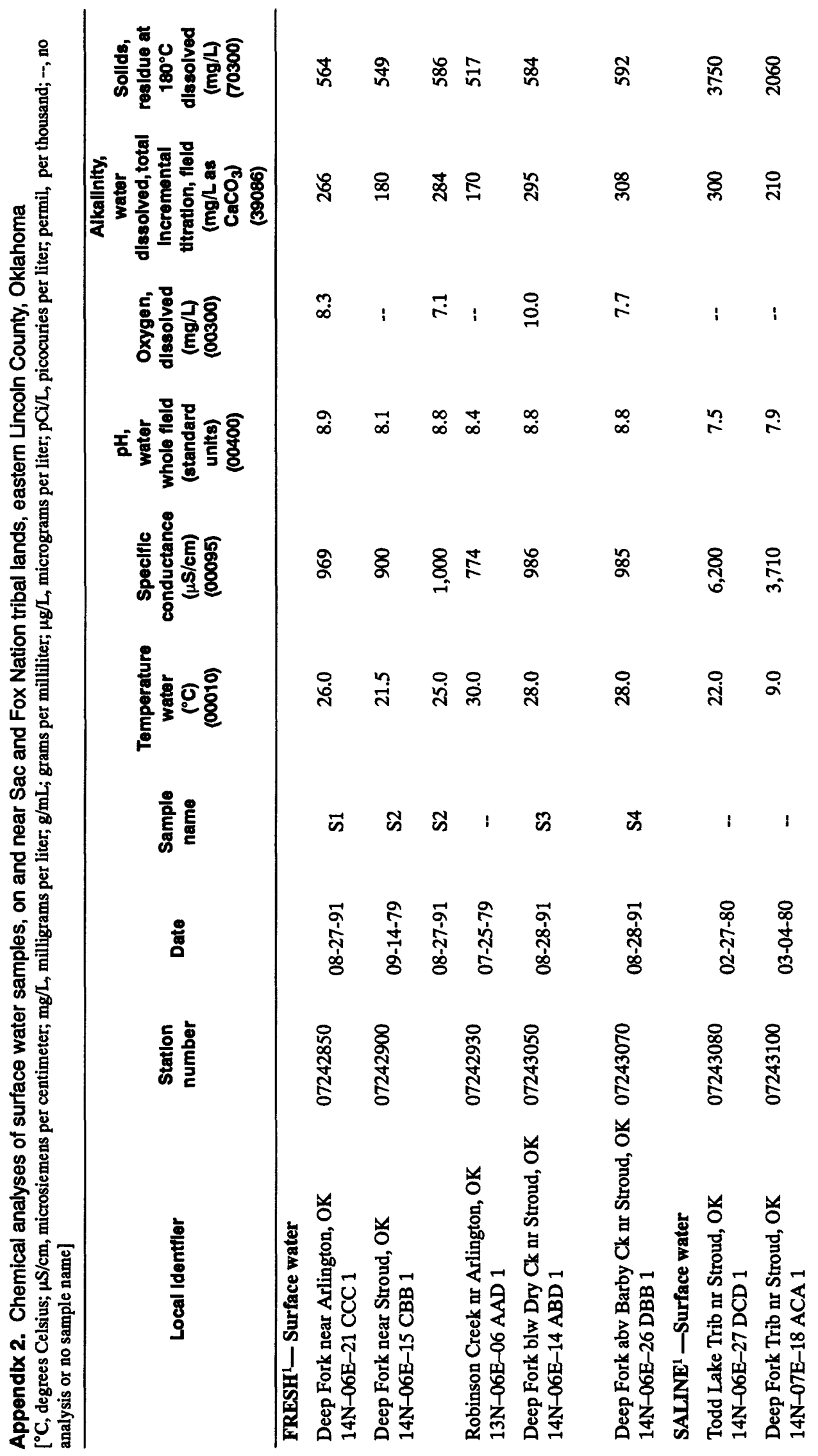




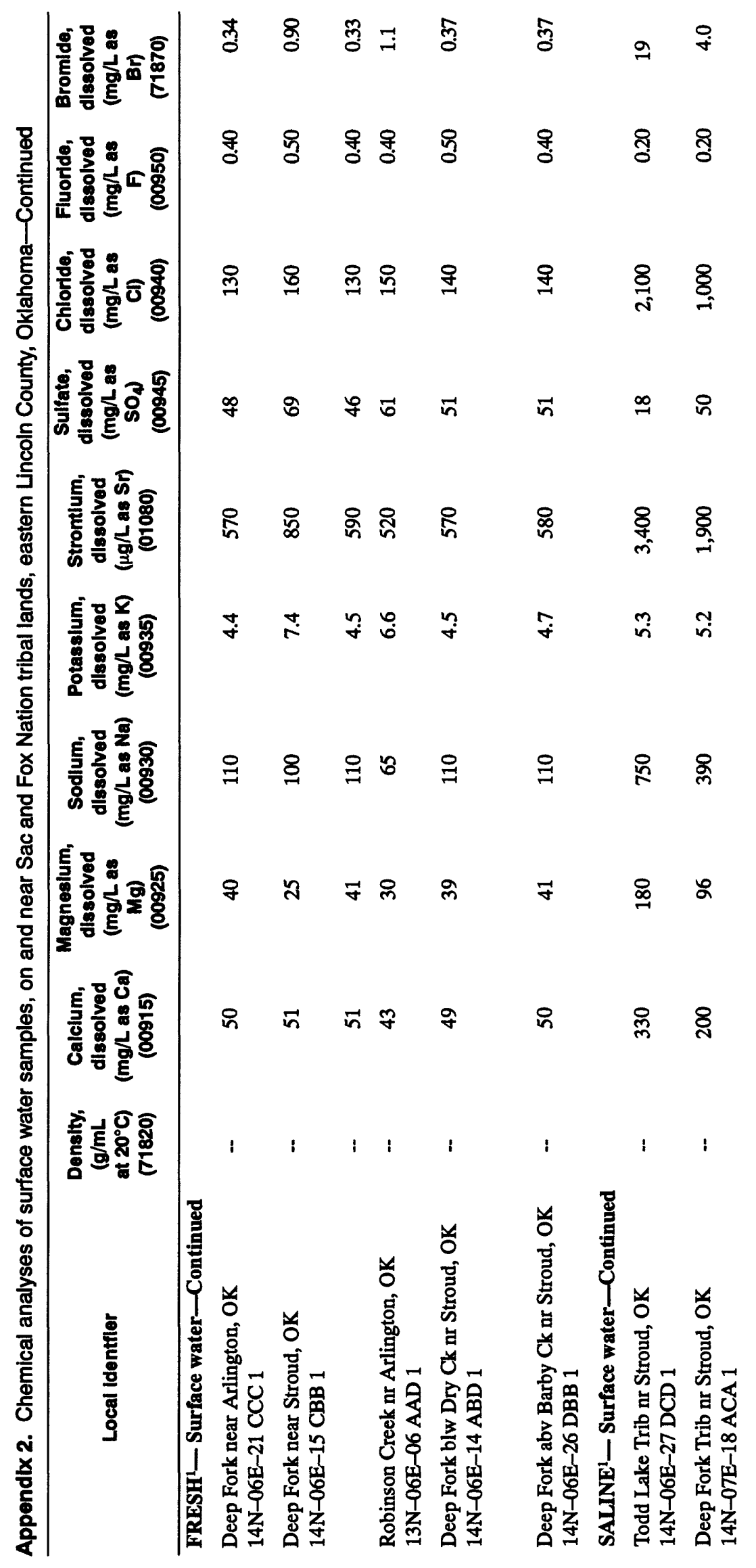




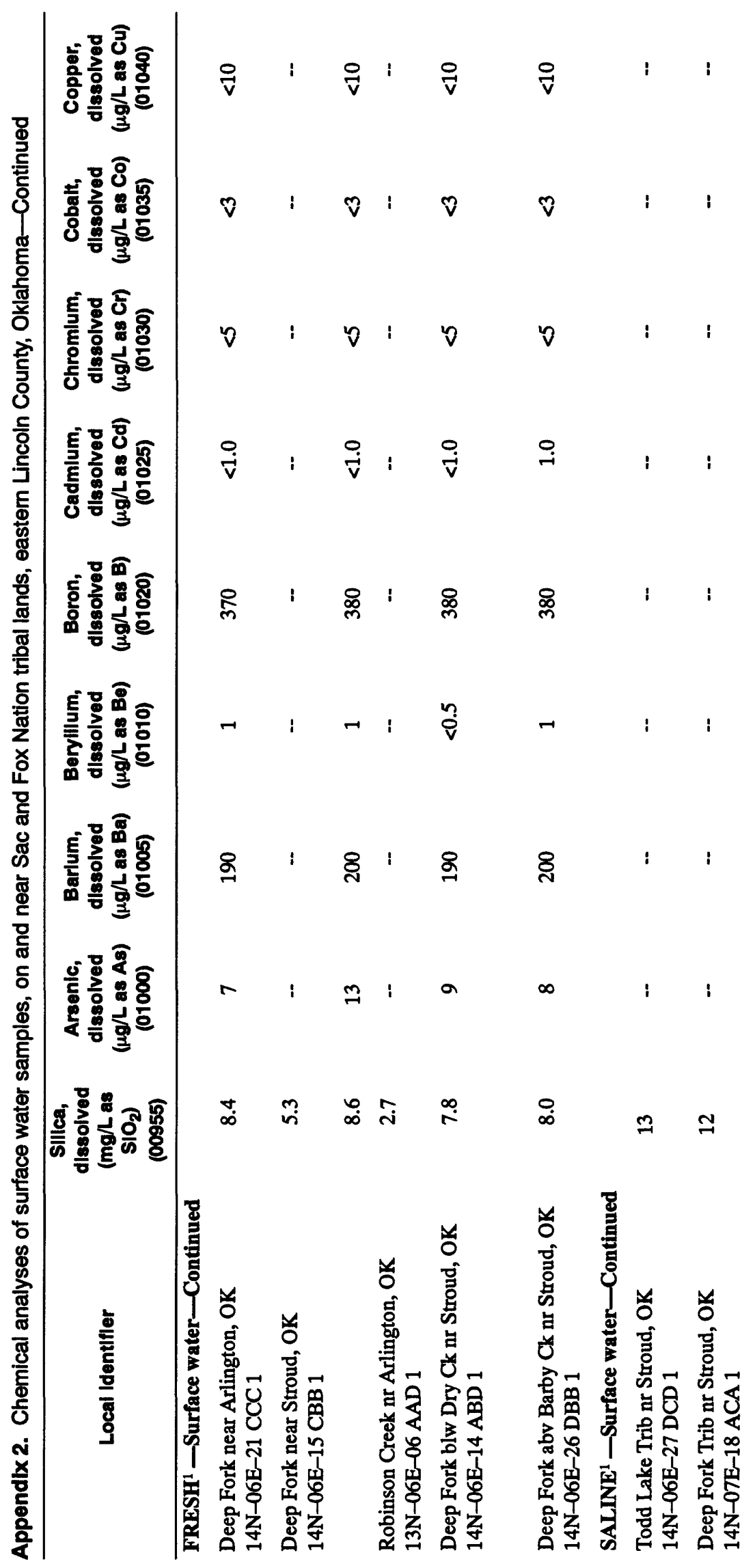




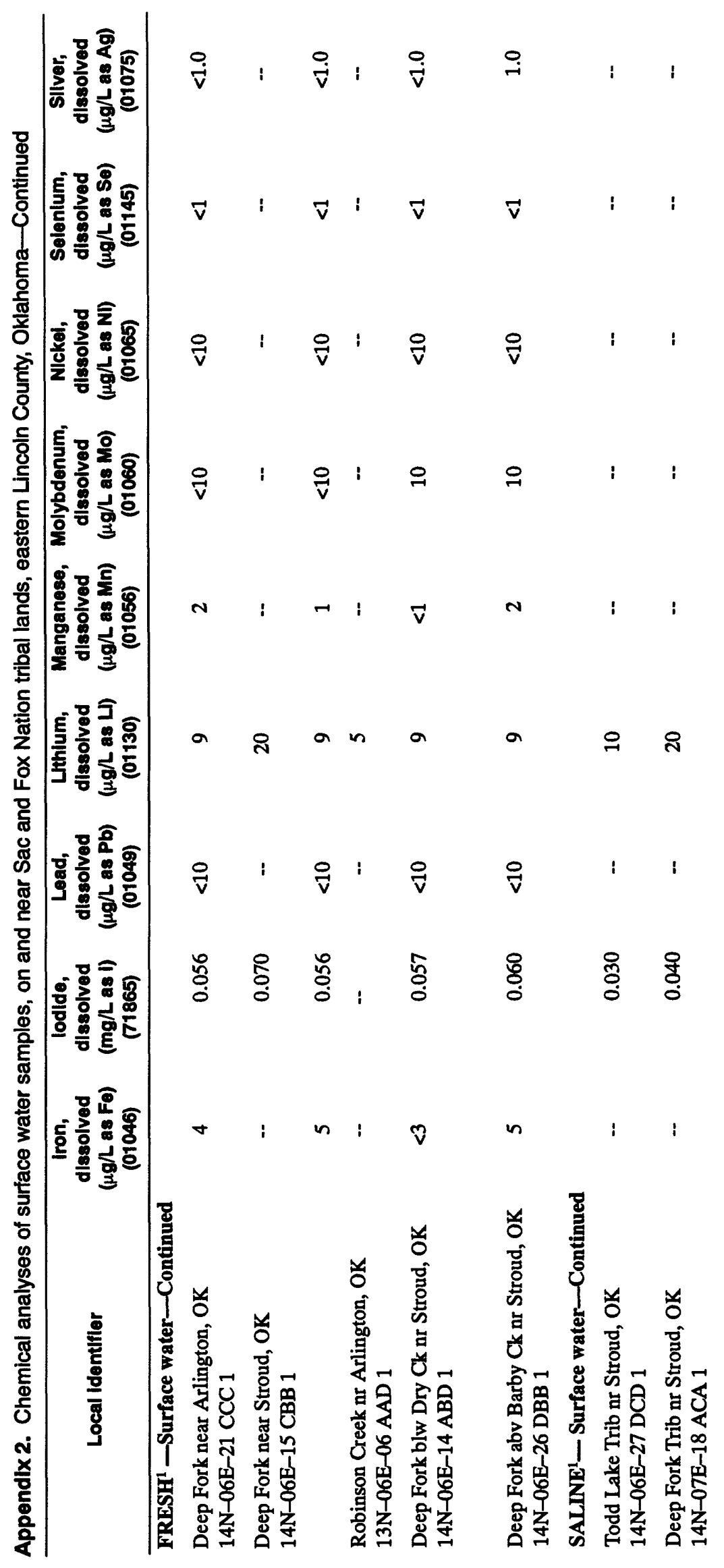




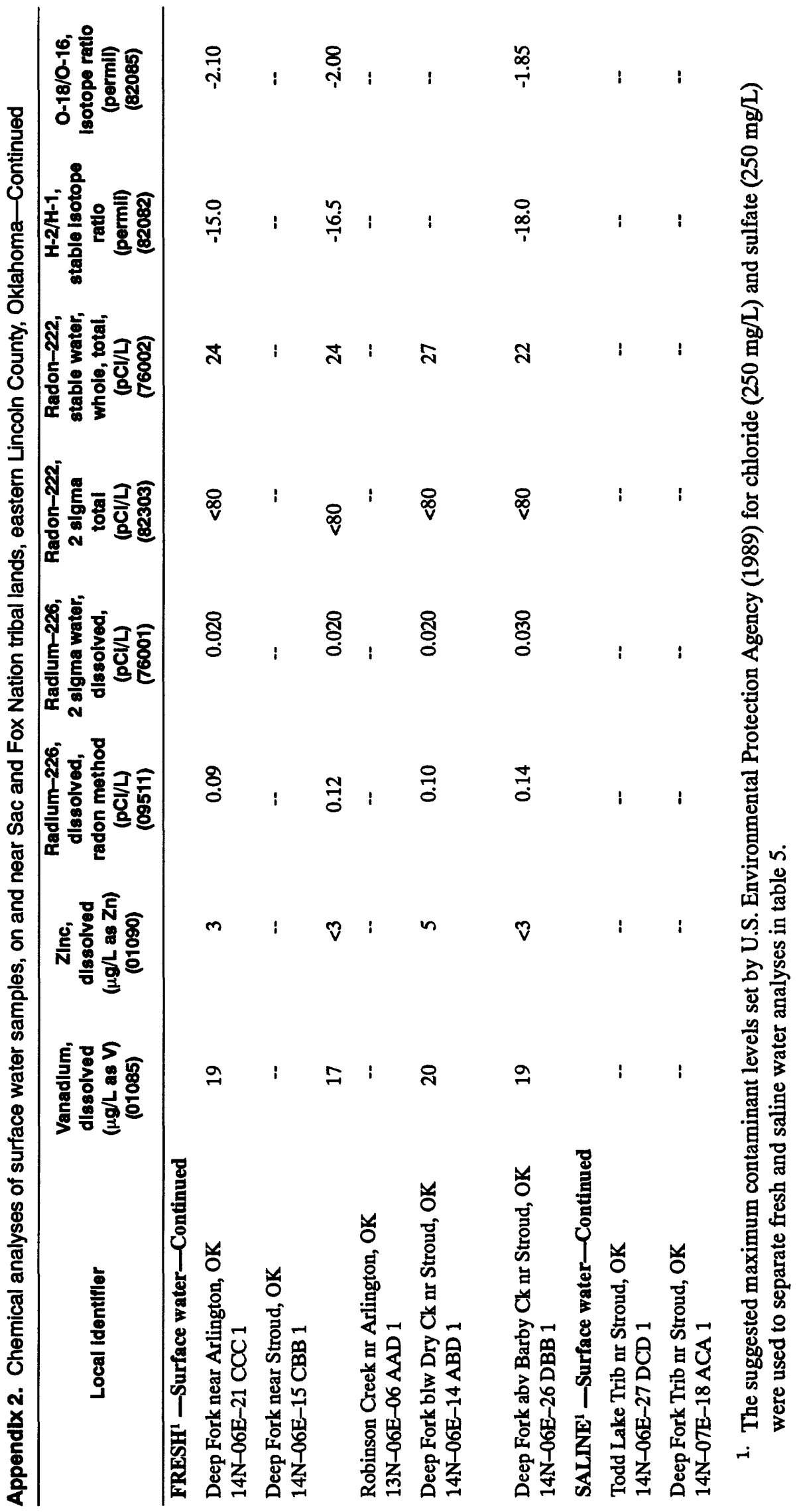

54 Freshwater resources and sallne water near the Sac and Fox Nation tribal lands, eastern LIncoln County, Oklahoma 
Appendlx 3. Depth to and altitude of base of fresh ground water in wells on and near Sac and Fox Nation tribal lands, eastern Lincoln County, Oklahoma

\begin{tabular}{|c|c|c|c|c|}
\hline Local Identifler & Date well logged & $\begin{array}{l}\text { Elevation of datum } \\
\text { (feet above sea level) }\end{array}$ & $\begin{array}{c}\text { Base of fresh water } \\
\text { (feet below land } \\
\text { surface) }\end{array}$ & $\begin{array}{l}\text { Altltude of base of } \\
\text { fresh water } \\
\text { (feet above sea level) }\end{array}$ \\
\hline 13N-06E-02 BBC & $12-15-65$ & 896 & 485 & 411 \\
\hline 13N-06E-02 BDB & $02-14-58$ & 861 & 470 & 391 \\
\hline $13 \mathrm{~N}-06 \mathrm{E}-02 \mathrm{CB}$ & $04-28-83$ & 865 & 655 & 210 \\
\hline $13 \mathrm{~N}-06 \mathrm{E}-02 \mathrm{CCC}$ & $07-23-69$ & 868 & 690 & 178 \\
\hline $13 \mathrm{~N}-06 \mathrm{E}-03 \mathrm{AAD}$ & $02-06-54$ & 876 & 460 & 416 \\
\hline $13 N-06 E-03$ ADD & $07-02-67$ & 916 & 715 & 201 \\
\hline 13N-06E-03 BCC & $06-20-84$ & 862 & 500 & 362 \\
\hline 13N-06E-03 DCD & $12-24-51$ & 905 & 675 & 230 \\
\hline $13 N-06 E-04$ AC & $07-19-51$ & 810 & 390 & 420 \\
\hline 13N-06E-04 CAC & $01-28-83$ & 792 & 460 & 332 \\
\hline 13N-06E-04 CDB & $10-07-52$ & 795 & 492 & 303 \\
\hline 14N-06E-09 AAA & $07-21-51$ & 828 & 365 & 463 \\
\hline 14N-06E-09 AAB & $06-30-55$ & 820 & 300 & 520 \\
\hline 14N-06E-09 ABA & $06-11-55$ & 879 & 450 & 429 \\
\hline 14N-06E-09 ACA & $03-02-55$ & 819 & 386 & 433 \\
\hline $14 \mathrm{~N}-06 \mathrm{E}-09$ ACB & 04-13-55 & 848 & 400 & 448 \\
\hline 14N-06E-09 ADA & $10-22-51$ & 821 & 360 & 461 \\
\hline $14 \mathrm{~N}-06 \mathrm{E}-09 \mathrm{ADB}$ & $05-08-55$ & 792 & 330 & 462 \\
\hline 14N-06E-09 BAA & $04-02-55$ & 862 & 345 & 517 \\
\hline 14N-06E-09 BAB & $05-05-55$ & 823 & 330 & 493 \\
\hline 14N-06E-09 BAC & $04-23-55$ & 823 & 350 & 473 \\
\hline $14 \mathrm{~N}-06 \mathrm{E}-09 \mathrm{BAD}$ & 03-19-55 & 847 & 340 & 507 \\
\hline $14 \mathrm{~N}-06 \mathrm{E}-09 \mathrm{BCD}$ & $06-15-55$ & 789 & 380 & 409 \\
\hline 14N-06E-09 BDA & $05-17-55$ & 830 & 385 & 445 \\
\hline 14N-06E-09 BDB & $06-05-55$ & 812 & 320 & 492 \\
\hline 14N-06E-09 BDC & $06-23-55$ & 787 & 310 & 477 \\
\hline $14 \mathrm{~N}-06 \mathrm{E}-09 \mathrm{CAB}$ & $05-27-55$ & 787 & 320 & 467 \\
\hline 14N-06E-09 CBA & $04-05-55$ & 831 & 375 & 456 \\
\hline 14N-06E-09 CBC & $10-17-82$ & 865 & 390 & 475 \\
\hline $14 \mathrm{~N}-06 \mathrm{E}-09 \mathrm{CDC}$ & $03-19-82$ & 845 & 400 & 445 \\
\hline
\end{tabular}


Appendlx 3. Depth to and altitude of base of fresh ground water in wells on and near Sac and Fox Nation tribal lands, eastern Lincoln County, Oklahoma - Continued

\begin{tabular}{|c|c|c|c|c|}
\hline Local Identifier & Date well logged & $\begin{array}{l}\text { Elevation of datum } \\
\text { (feet above sea level) }\end{array}$ & $\begin{array}{l}\text { Base of fresh water } \\
\text { (foet below land } \\
\text { surface) }\end{array}$ & $\begin{array}{c}\text { Altitude of base of } \\
\text { fresh water } \\
\text { (feet above sea level) }\end{array}$ \\
\hline $14 \mathrm{~N}-06 \mathrm{E}-10 \mathrm{AAC}$ & $04-14-57$ & 790 & 340 & 450 \\
\hline $14 \mathrm{~N}-06 \mathrm{E}-10 \mathrm{ABC}$ & $08-14-51$ & 802 & 295 & 507 \\
\hline 14N-06E-10 BAC & $11-02-51$ & 868 & 454 & 414 \\
\hline 14N-06E-10 BBC & $01-08-52$ & 844 & 460 & 384 \\
\hline 14N-06E-10 BBA & $02-04-52$ & 845 & 450 & 395 \\
\hline 14N-06E-10 BBB & $06-07-51$ & 880 & 490 & 390 \\
\hline 14N-06E-10 BCA & $12-14-51$ & 865 & 395 & 470 \\
\hline $14 \mathrm{~N}-06 \mathrm{E}-10 \mathrm{BCB}$ & $09-24-51$ & 856 & 360 & 496 \\
\hline 14N-06E-14 ACD & $11-18-64$ & 779 & 170 & 609 \\
\hline 14N-06E-14 BAB & $05-14-62$ & 780 & 292 & 488 \\
\hline 14N-06E-14 BBD & $06-12-63$ & 779 & 290 & 489 \\
\hline $14 \mathrm{~N}-06 \mathrm{E}-14 \mathrm{BCA}$ & $06-18-63$ & 778 & 300 & 478 \\
\hline 14N-06E-14 BDA & $04-13-62$ & 778 & 245 & 533 \\
\hline 14N-06E-14 BDC & $08-06-62$ & 788 & 330 & 458 \\
\hline 14N-06E-14 CAD & $01-16-63$ & 797 & 258 & 539 \\
\hline $14 \mathrm{~N}-06 \mathrm{E}-14 \mathrm{CDC}$ & $05-15-53$ & 796 & 170 & 626 \\
\hline 14N-06E-14 DBB & $08-21-62$ & 786 & 180 & 606 \\
\hline 14N-06E-14 DCD & $11-14-53$ & 779 & 140 & 639 \\
\hline 14N-06E-15 DCD & $05-25-53$ & 804 & 270 & 534 \\
\hline 14N-06E-15 DDC & $05-03-53$ & 786 & 220 & 566 \\
\hline 14N-06E-15 DDD & $05-14-53$ & 797 & 270 & 527 \\
\hline 14N-06E-21 AAD & $01-01-53$ & 792 & 90 & 702 \\
\hline $14 \mathrm{~N}-06 \mathrm{E}-21 \mathrm{ACB}$ & $03-13-53$ & 810 & 160 & 650 \\
\hline 14N-06E-21 ACC & $01-01-52$ & 826 & 160 & 666 \\
\hline 14N-06E-21 CBA & $02-24-53$ & 827 & 150 & 677 \\
\hline 14N-06E-21 DAA & $02-12-53$ & 838 & 170 & 668 \\
\hline 14N-06E-21 DAB & $02-24-53$ & 827 & 170 & 657 \\
\hline $14 \mathrm{~N}-06 \mathrm{E}-21 \mathrm{DCC}$ & $03-18-71$ & 815 & 130 & 685 \\
\hline $14 \mathrm{~N}-06 \mathrm{E}-21 \mathrm{DDC}$ & $04-18-70$ & 835 & 190 & 645 \\
\hline $14 \mathrm{~N}-06 \mathrm{E}-22$ AAC & $03-17-53$ & 799 & 170 & 629 \\
\hline
\end{tabular}


Appendlx 3. Depth to and altitude of base of fresh ground water in wells on and near Sac and Fox Nation tribal lands, eastern Lincoln County, Oklahoma - Continued

\begin{tabular}{|c|c|c|c|c|}
\hline Local Identifier & Date well logged & $\begin{array}{l}\text { Elevation of datum } \\
\text { (feet above sea level) }\end{array}$ & $\begin{array}{c}\text { Base of fresh water } \\
\text { (feet below land } \\
\text { surface) }\end{array}$ & $\begin{array}{l}\text { Altitude of base of } \\
\text { fresh water } \\
\text { (feet above sea level) }\end{array}$ \\
\hline $14 \mathrm{~N}-06 \mathrm{E}-22 \mathrm{AAA}$ & $09-12-70$ & 790 & 176 & 614 \\
\hline $14 \mathrm{~N}-06 \mathrm{E}-22 \mathrm{ABA}$ & $03-13-53$ & 808 & 175 & 633 \\
\hline $14 \mathrm{~N}-06 \mathrm{E}-22 \mathrm{DBC}$ & $03-04-54$ & 850 & 140 & 710 \\
\hline $14 \mathrm{~N}-06 \mathrm{E}-22 \mathrm{BBC}$ & $04-26-53$ & 822 & 135 & 687 \\
\hline $14 \mathrm{~N}-06 \mathrm{E}-22 \mathrm{BCB}$ & $01-12-53$ & 844 & 170 & 674 \\
\hline $14 \mathrm{~N}-06 \mathrm{E}-22 \mathrm{CBB}$ & $02-08-53$ & 843 & 145 & 698 \\
\hline $14 \mathrm{~N}-06 \mathrm{E}-22 \mathrm{CCC}$ & $02-07-71$ & 838 & 173 & 665 \\
\hline $14 \mathrm{~N}-06 \mathrm{E}-22 \mathrm{CDB}$ & $09-30-53$ & 850 & 170 & 680 \\
\hline $14 \mathrm{~N}-06 \mathrm{E}-22 \mathrm{DBD}$ & $11-02-54$ & 803 & 110 & 693 \\
\hline $14 \mathrm{~N}-06 \mathrm{E}-22 \mathrm{DCB}$ & $02-06-54$ & 882 & 175 & 707 \\
\hline 14N-06E-23 AAC & $07-17-55$ & 775 & 160 & 615 \\
\hline $14 \mathrm{~N}-06 \mathrm{E}-23 \mathrm{ABA}$ & $10-11-53$ & 779 & 155 & 624 \\
\hline $14 \mathrm{~N}-06 \mathrm{E}-23 \mathrm{ABB}$ & $08-10-53$ & 778 & 180 & 598 \\
\hline 14N-06E-23 ABD & $03-12-53$ & 824 & 185 & 639 \\
\hline $14 \mathrm{~N}-06 \mathrm{E}-26 \mathrm{ABC}$ & $11-21-51$ & 838 & 280 & 558 \\
\hline $14 \mathrm{~N}-06 \mathrm{E}-26 \mathrm{ACC}$ & $07-14-64$ & 781 & 215 & 566 \\
\hline $14 \mathrm{~N}-06 \mathrm{E}-26 \mathrm{CAA}$ & $04-03-54$ & 783 & 260 & 523 \\
\hline $14 \mathrm{~N}-06 \mathrm{E}-26 \mathrm{CCC}$ & $02-24-54$ & 772 & 270 & 502 \\
\hline $14 \mathrm{~N}-06 \mathrm{E}-26 \mathrm{CCD}$ & $03-10-54$ & 770 & 240 & 530 \\
\hline 14N-06E-26 DDA & $10-28-71$ & 812 & 260 & 552 \\
\hline 14N-06E-26 DDC & $01-31-78$ & 820 & 190 & 630 \\
\hline 14N-06E-27 BBA & $09-23-92$ & 875 & 72 & 803 \\
\hline 14N-06E-27 CAB & $01-23-85$ & 864 & 395 & 469 \\
\hline 14N-06E-27 CAD & $06-29-82$ & 859 & 385 & 474 \\
\hline $14 \mathrm{~N}-06 \mathrm{E}-27 \mathrm{CDA}$ & $12-10-53$ & 833 & 360 & 473 \\
\hline 14N-06E-27 CBB & $01-13-85$ & 856 & 420 & 436 \\
\hline $14 \mathrm{~N}-06 \mathrm{E}-27 \mathrm{CCD}$ & $12-04-53$ & 841 & 353 & 488 \\
\hline 14N-06E-27 CDD & $11-17-53$ & 795 & 335 & 460 \\
\hline $14 \mathrm{~N}-06 \mathrm{E}-27 \mathrm{DBD}$ & $11-06-53$ & 773 & 290 & 483 \\
\hline $14 \mathrm{~N}-06 \mathrm{E}-28 \mathrm{AAB}$ & $06-08-53$ & 842 & 190 & 652 \\
\hline
\end{tabular}


Appendix 3. Depth to and altitude of base of fresh ground water in wells on and near Sac and Fox Nation tribal lands, eastern Lincoln County, Oklahoma - Continued

\begin{tabular}{|c|c|c|c|c|}
\hline Local Identifler & Date well logged & $\begin{array}{l}\text { Elevation of datum } \\
\text { (feet above sea level) }\end{array}$ & $\begin{array}{l}\text { Base of fresh water } \\
\text { (feet below land } \\
\text { surface) }\end{array}$ & $\begin{array}{l}\text { Altitude of base of } \\
\text { fresh water } \\
\text { (feet above sea level) }\end{array}$ \\
\hline 14N-06E-28 ABA & $05-13-71$ & 828 & 165 & 663 \\
\hline 14N-06E-33 AAD & $03-03-54$ & 868 & 440 & 428 \\
\hline 14N-06E-33 DBD & $05-01-51$ & 822 & 453 & 369 \\
\hline 14N-06E-34 BAA & $10-07-53$ & 851 & 400 & 451 \\
\hline 14N-06E-34 AAA & $12-22-53$ & 785 & 297 & 488 \\
\hline 14N-06E-34 ABA & $11-29-53$ & 791 & 330 & 461 \\
\hline $14 \mathrm{~N}-06 \mathrm{E}-34 \mathrm{ABB}$ & $11-21-51$ & 800 & 330 & 470 \\
\hline 14N-06E-34 BAC & $09-16-53$ & 864 & 450 & 414 \\
\hline 14N-06E-34 BAD & $10-07-53$ & 857 & 395 & 462 \\
\hline 14N-06E-34 BBA & $09-22-53$ & 863 & 450 & 413 \\
\hline 14N-06E-34 BBB & $09-02-53$ & 841 & 425 & 416 \\
\hline 14N-06E-34 BBC & $08-13-53$ & 872 & 460 & 412 \\
\hline $14 \mathrm{~N}-06 \mathrm{E}-34 \mathrm{CA}$ & $04-24-82$ & 870 & 455 & 415 \\
\hline 14N-06E-34 DAB & $01-21-55$ & 809 & 350 & 459 \\
\hline 14N-06E-34 DBB & $10-23-53$ & 863 & 425 & 438 \\
\hline $14 \mathrm{~N}-06 \mathrm{E}-35 \mathrm{AAB}$ & $01-05-54$ & 816 & 260 & 556 \\
\hline 14N-06E-35 BAA & $12-29-53$ & 849 & 260 & 589 \\
\hline $14 \mathrm{~N}-06 \mathrm{E}-35 \mathrm{BA}$ & $12-19-77$ & 800 & 230 & 570 \\
\hline $14 \mathrm{~N}-06 \mathrm{E}-35 \mathrm{BAB}$ & $03-20-54$ & 795 & 240 & 555 \\
\hline 14N-06E-35 BBA & $04-23-54$ & 802 & 260 & 542 \\
\hline $14 \mathrm{~N}-06 \mathrm{E}-35 \mathrm{BDC}$ & $11-16-55$ & 834 & 265 & 569 \\
\hline 14N-06E-35 CBB & $10-27-53$ & 834 & 330 & 504 \\
\hline
\end{tabular}

